\title{
Three Essays on the Political Economy of Foreign Aid Practices in the Development Assistance Committee Countries
}

Jared A. Pincin

West Virginia University

Follow this and additional works at: https://researchrepository.wvu.edu/etd

\section{Recommended Citation}

Pincin, Jared A., "Three Essays on the Political Economy of Foreign Aid Practices in the Development Assistance Committee Countries" (2011). Graduate Theses, Dissertations, and Problem Reports. 3388. https://researchrepository.wvu.edu/etd/3388

This Dissertation is protected by copyright and/or related rights. It has been brought to you by the The Research Repository @ WVU with permission from the rights-holder(s). You are free to use this Dissertation in any way that is permitted by the copyright and related rights legislation that applies to your use. For other uses you must obtain permission from the rights-holder(s) directly, unless additional rights are indicated by a Creative Commons license in the record and/ or on the work itself. This Dissertation has been accepted for inclusion in WVU Graduate Theses, Dissertations, and Problem Reports collection by an authorized administrator of The Research Repository @ WVU. For more information, please contact researchrepository@mail.wvu.edu. 


\title{
Three Essays on the Political Economy of Foreign Aid Practices in the Development Assistance Committee Countries
}

\author{
Jared A. Pincin
}

Dissertation submitted to the College of Business and Economics at West Virginia University in partial fulfillment of the requirements

for the degree of

Doctor of Philosophy

in

Economics

Russell S. Sobel, Ph.D., co-Chair Christopher J. Coyne, Ph.D., co-Chair

Tami Gurley-Calvez, Ph.D.

Andrew T. Young, Ph.D. Santiago Pinto, Ph.D.

Department of Economics

Morgantown, West Virginia

2011

Keywords: Official Development Assistance (ODA), tied aid, disaggregated aid, fragmented government, political economy, UN General Assembly, voting 


\section{Abstract \\ Three Essays on the Political Economy of Foreign Aid Practices in the Development Assistance Committee Countries}

\section{Jared A. Pincin}

This dissertation is a collection of essays on the political economy of foreign aid in the Development Assistance Committee (DAC) countries. Chapter 1 provides an overview of the foreign aid literature, focusing on the practice of aid tying and foreign aid's impact on political support between aid donor and recipient countries. Chapter 2 investigates the hypothesis that institutional factors such as fragmentation of the executive power and the position of government vis-à-vis legislative composition within the governments of DAC countries help explain why levels of tied aid remain significantly above zero despite the push in the development community to untie all bilateral foreign aid. The results show as the executive power becomes more fragmented, particularly as the number of spending ministers and the number of political parties in the governing coalition increases, countries increase the level of tied aid. Chapter 3 empirically tests whether the DAC countries use aid disbursements to exert political influence over aid recipients by influencing how the recipients vote in the United Nations General Assembly. In general, the results show a positive relationship between voting coincidence and foreign aid distribution for Canada, France, Spain, and the United Kingdom while no conclusive link was established for the United States. These results may be considered a lower bound of political influence because of the possibility of free riding among the DAC countries. Chapter 4 extends the work in the previous chapter by disaggregating the aid data to account for the heterogeneity of aid and the possibility that the different categories and forms of aid may differ in their ability to induce political support. The analysis shows, among other things, that in the post Cold War era disaggregated aid measures do not show a robust influence on voting coincidence for most of the DAC countries. These results in chapters 3 and 4 may differ because recipients may value total aid more than individual aid categories because of the fungibility of aid. Chapter 5 concludes the dissertation by summarizing the key findings and offering extensions to the current research. 


\section{Acknowledgments}

The author would like to thank the members of the dissertation committee: Dr. Russell S. Sobel, Dr. Christopher J. Coyne, Dr. Tami Gurley-Calvez, Dr. Andrew T. Young, and Dr. Santiago Pinto, whose valuable suggestions, beneficial advice, immeasurable patience, and stimulating conversations lead to the fruition of this work.

Special thanks are also due to the author's beautiful wife, Jennifer, and parents, Michael and Ivelyn Pincin, whose support has been critical for my academic and professional pursuits as well as personal development.

The author would also like to thank his Lord and Savior Jesus Christ, whose life, death, and resurrection are the reason for his eternal salvation and joy and to Whom all glory, honor, and power rightfully reside. 


\section{Table of Contents}

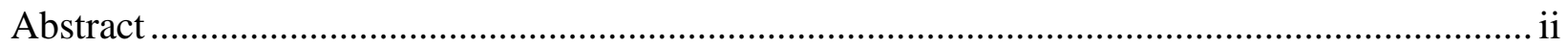

Acknowledgments..........................................................................................................ii

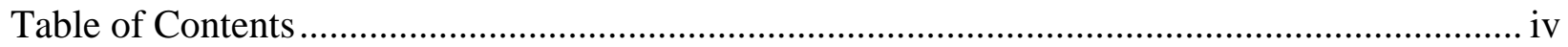

List of Tables and Figures................................................................................................ vi

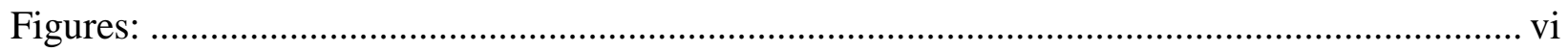

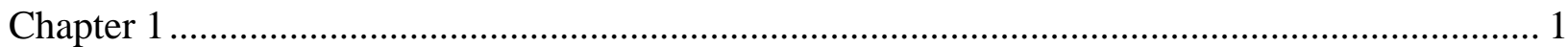

The Political Economy of Foreign Aid and the Development Assistance Committee.................... 1

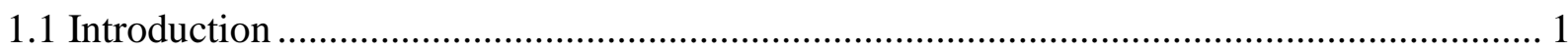

1.2 Politically Tied: Political Power and Aid Tying Practices in the Development Assistance

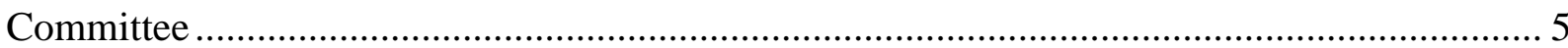

1.3 Exerting Political Influence: Does Foreign Aid of Development Assistance Committee

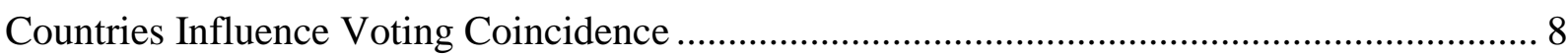

1.4 Disaggregated Foreign Aid and Voting Coincidence in the Development Assistance

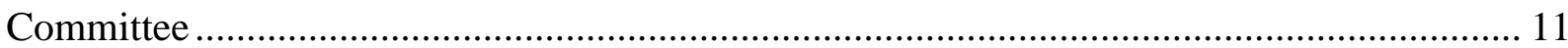

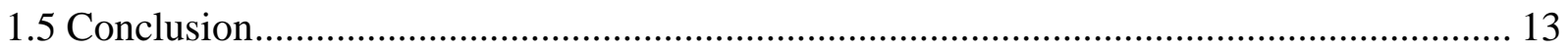

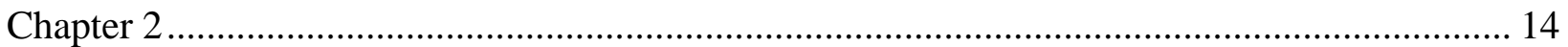

Political Power and Aid Tying Practices in the Development Assistance Committee Countries 14

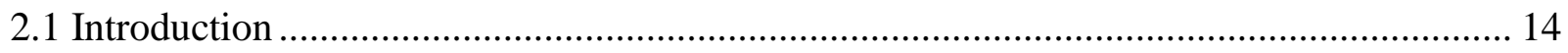

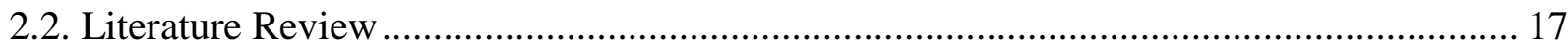

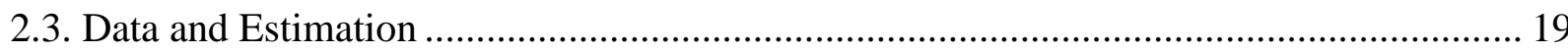

2.3.1 Descriptions of data and variables............................................................................... 19

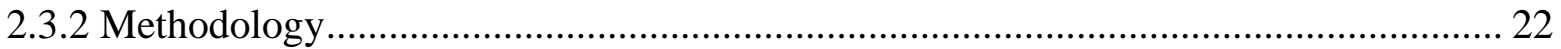

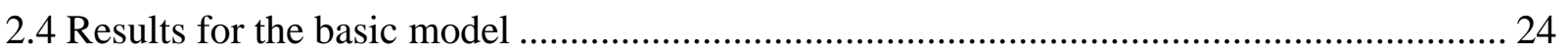





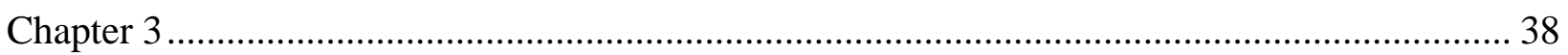

Exerting Political Influence: Does Foreign Aid of Development Assistance Committee Countries

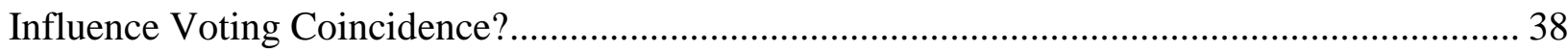

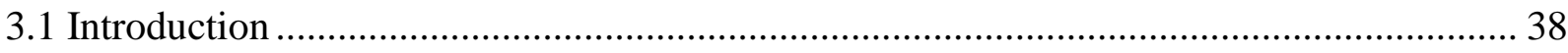

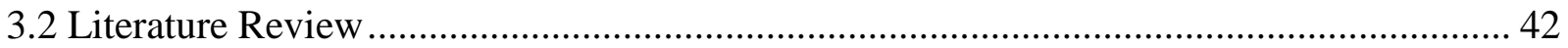




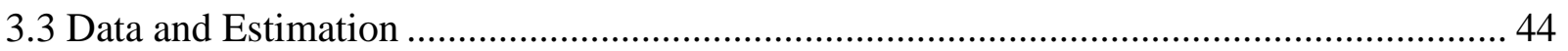

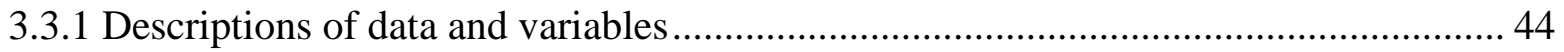



3.4. Results for the basic model ......................................................................................... 49

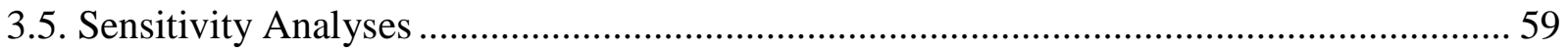

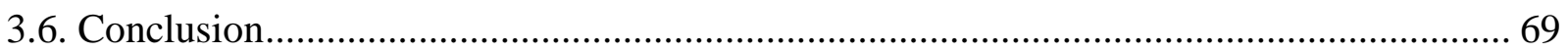

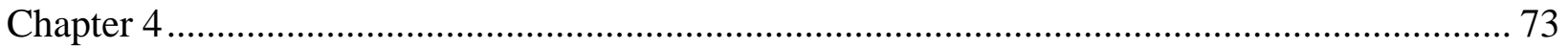

Political Influence and Development Assistance: A Disaggregated Analysis of Development Assistance Distribution and the Development Assistance Committee Countries ......................... 73

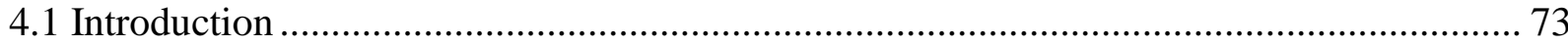

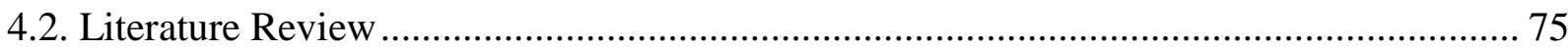

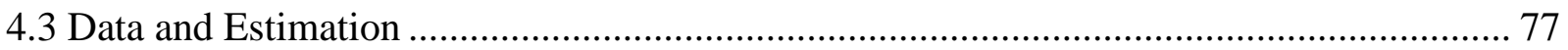

4.3.1 Descriptions of data and variables.............................................................................. 77

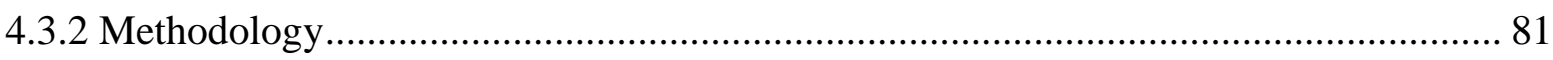

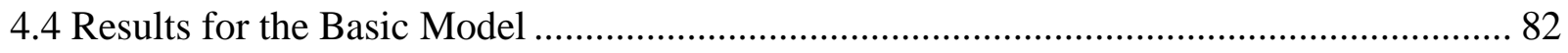

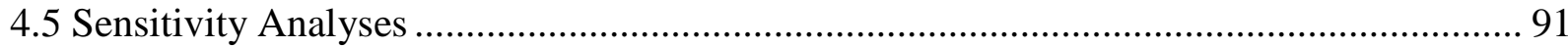

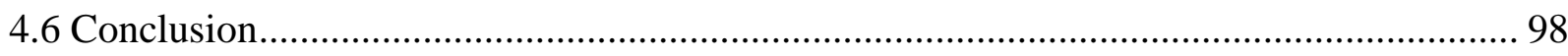





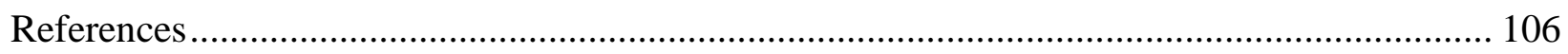

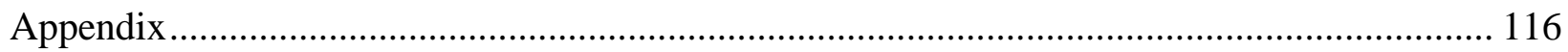

Appendix 2A: Variable Description and Sources ……………………............................ 116

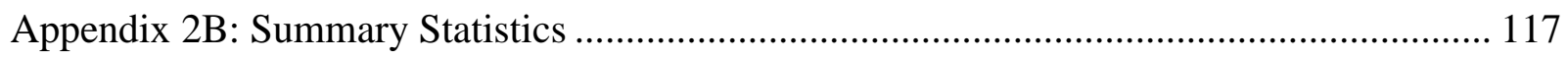

Appendix 2C: Political size fragmentation variables correlation matrix ............................... 118

Appendix 2D: All Political Variables ............................................................................ 119

Appendix 3A: Variable Description and Sources …………............................................ 120

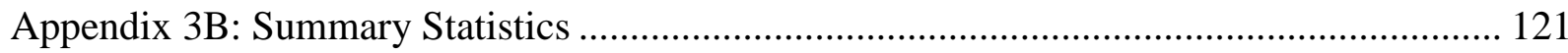

Appendix 4A: Variable Description and Source.............................................................. 122 


\section{Tables:}

\section{List of Tables and Figures}

Table 2.1: The impact of size fragmentation on tied aid (Full Sample)..... 25

Table 2.2: The impact of the government's position vis-à-vis legislative composition on tied aid (Full Sample) 27

Table 2.3: The impact of size fragmentation on tied aid (1979-1996) ..... 31

Table 2.4: The impact of the government's position vis-à-vis legislative composition on tied aid (1979-1996) 32

Table 2.5: The impact of size fragmentation on tied aid (1997-2009) 33

Table 2.6: The impact of the government's position vis-à-vis legislative composition on tied aid (1997-2009) 34

Table 3.1: Bilateral ODA and UN Voting for ODA Giving Countries (OLS and 2SLS) .......... 56

Table 3.2: Bilateral Aid and UN Voting for ODA Giving Countries (GMM) ......................... 58

Table 3.3: Bilateral Aid and UN Voting for ODA Giving Countries Including GDP Per Capita (GMM)

Table 3.4: Bilateral Aid and UN Voting for ODA Giving Countries Including GDP Growth (GMM) 64

Table 3.6: Bilateral Aid and UN Voting for ODA Giving Countries Including AFPTL (GMM) 66 Table 3.7: Bilateral Aid and UN Voting for ODA Giving Countries Including Imports (GMM) 67 Table 3.8: Bilateral Aid and UN Voting for ODA Giving Countries Including Exports (GMM) 68 Table 3.9: Average Voting Coincidence Rates Among Development Assistance Committee

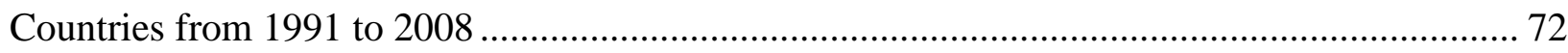

Table 4.1: Project, Program, and Humanitarian ODA and UN Voting for DAC Countries ........ 88 Table 4.2: Project, Program Disaggregated, and Humanitarian ODA and UN Voting for DAC

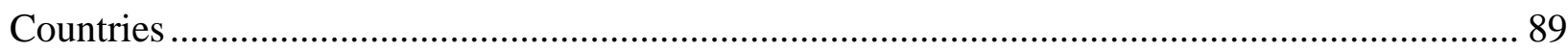

Table 4.3: Grants, Loans and UN Voting for DAC Countries................................................ 90

Table 4.4: Bilateral Aid and UN Voting, Tests for Robustness........................................... 93

\section{Figures:}

Figure 2.1: Total Amount and Percentage of Tied Aid of Development Assistance Committee: 1979-2009 
Figure 2.2: Total Net Official Development Assistance 1960-2009

Figure 3.1: Proportion of Total Official Development Assistance by Organization 1991-2008.. 40 Figure 3.2: Total Bilateral Official Development Assistance by Development Assistance Committee Countries 1991-2008

Figure 3.3: Proportion of Official Development Assistance Given by the Top 10 Development Assistance Committee Countries 1991-2008

Figure 3.4: Official Development Assistance and Voting Coincidence for Select Countries 1991- 


\section{Chapter 1}

\section{The Political Economy of Foreign Aid and the Development Assistance Committee}

\subsection{Introduction}

The contemporary version of foreign aid began with the rebuilding of the European and Pacific theaters after the Second World War. This modern act of international cooperation was best illustrated by the Marshall Plan and the establishment of the Bretton Woods institutions, the International Monetary Fund (IMF) and the World Bank, which were used to facilitate capital investment for the post war reconstruction. Throughout the following decades, the nature of foreign aid has transitioned through numerous permutations, often dictated by donor preferences.

In the 1950's, with the rebuilding process largely successful and the Cold War becoming the major international foreign policy focus, bilateral foreign aid by Western powers shifted focus to fighting communism and expanding Western influence (Schraeder et al. 1998). During the 1960's, the shadow of the Cold War pushed foreign aid donors from the East and the West to compete against each other in helping less developed countries industrialize in an effort to secure political support. By the 1970's, foreign aid shifted focus away from industrialization and towards poverty reduction. This new focus led to the United Nations adopting a resolution in October of 1970 asking wealthy countries to give 0.7 percent of their national income to foreign aid. The debt crisis in the developing world during the 1980's moved aid away from poverty reduction and towards structural adjustment to contain the possibility of developing countries defaulting on foreign loans, which would have severely damaged the banking system of the developed countries. The end of the Cold War brought back to the forefront political pressures as aid was funneled to countries shedding communism and adopting market ideals (Boschini and 
Olofsgard 2001) and supporting other foreign policy objectives (Zimmerman 1993 and Ruttan 1996). By the turn of the millennium, donors turned towards social development in recipient countries (Moyo 2009), such as the adoption of the Millennium Development Goals (MDG's), and fighting terrorism (Harrigan et al. 2006), particularly the United States, as their main foreign aid goals. ${ }^{1}$

As the nature of foreign aid has evolved through time, the foreign aid literature became vast and covered a variety of topics. These included the effectiveness of aid (Friedman 1958, Chenery and Strout 1966, Bauer 1972, Burnside and Dollar 2000, Sachs 2005, and Easterly 2006), the fungibility of aid (Boone 1996 and McGillivray and Morrissey 2000), aid's potential to enrich donors while impoverishing recipients (Leontief 1936 and Bhagwati et al. 1985), and even aid's impact on the environment (Chao and Yu 1999). However, while much of the foreign aid research has focused on economic outcomes, foreign aid has always contained a political nature (Morgenthau 1962, O’Leary 1967, and Nelson 1968) where political factors and donor intention influence the distribution of foreign aid.

In particular, two areas of pertinence to this dissertation that relate to the political nature and donor intentions of aid are why donor countries tie aid to recipient countries and the direct and indirect ways donor countries solicit political support from recipient countries through foreign aid commitments and disbursements. The focus of this dissertation is placed on the Development Assistance Committee Countries (DAC) for three reasons. First, they are the Organization for Economic Co-operation and Development's (OECD) main committee focusing "on the important area of public policy that involves the provision of development assistance."

\footnotetext{
${ }^{1}$ Besides the motivations mentioned above, more traditional motivations for foreign aid distribution include colonial relations, trade relations, geographical proximity, and cultural homogeneity (Alesina and Dollar 2000, Boschini and Olofsgaard 2001, and Neumayer 2003).
} 
Second, they are the primary donors of ODA. Lastly, each member country of the DAC is determined by the OECD to have a significant foreign aid program (OECD 2009).

Even though the practice of aid tying is discouraged, it is still practiced to some degree by most large donor countries. Economic reasons for tying aid include stimulating employment, bolstering exports (Tajoli 1999), improving the balance of payments, and strengthening individual sectors in the aid donor country (Jepma 1991). Political reasons for aid tying include satisfying strong lobbying groups (Lahiri and Raimondos-Moller 2000), "directing” the political relationship between aid donor and aid recipient countries (Rai 1980 and Palmer 2002), and reforming the internal governing of the aid recipient countries (World Bank 1998, Woods 2000, and Hermes and Lensink 2001). An area receiving little attention is whether the internal political structure of the donor country government affects the tying practices of foreign aid. Since most DAC countries are parliamentary democracies with varying degrees of political power dispersion and size fragmentation in their governing coalition, these governing coalitions confront diverse political incentives and may behave accordingly. Aid tying is inherently a political process so political competition within each DAC country, as driven by the internal political structure, may cause different countries to behave differently in aid tying practices.

The political economy literature has two distinct strands in how political competition works. One strand finds political competition increases the public sector's efficiency (Stigler 1972, Wittman 1989, and Besley et al. 2010). The second strand argues political competition leads to inefficiency in the public sector which causes greater public sector expenditures, deficits, and debts (Roubini and Sachs 1989a and 1989b, De Haan and Strum 1994, and Volkerink and De Haan 2001). However, to date no research has examined how political 
competition is related to the practice of aid tying by DAC countries despite its attractive possibility. Chapter 2 of this dissertation explores this avenue of research.

How foreign aid induces recipients to provide donors with political support can be broken into two segments within the literature. The first examines indirect ways donor countries solicit additional political support from recipient countries. Kuziemko and Werker (2006) find nonpermanent members of the UN Security Council receive additional foreign aid, assumed to be targeted at influencing voting behavior, from the United States and the UN just for their council membership. Dreher and Sturm (2006) show that while overall bilateral aid by G7 donors does not influence UN voting behavior (a direct attempt at influencing voting), countries receiving financial support from the International Monetary Fund and World Bank (an indirect way to influence voting) do vote more frequently with G7 countries.

The second segment of research considers direct ways donor countries seek political support from recipient countries through the use of bilateral aid and its effects on UN voting behavior. Dreher and Sturm (2006) summarize many of the main findings and find the empirical evidence is inconclusive and mixed. Kato (1969), Kegley and Hook (1991), Sexton and Decker (1992), and Morey and Lai (2006) fail to find evidence that aid is an effective tool in influencing voting behavior. However, Bernstein and Alpert (1971), Rai (1972 and 1980), Wittkopf (1973), Lundborg (1998), Wang (1999), and Dreher et al. (2008) do find evidence that foreign aid increases voting coincidence between the aid donor and aid recipient countries.

Two details should be noted about the preceding literature investigating foreign aid's effect on voting behavior. In each of these studies except for Wittkopf (1973), who focuses on the 16 members of the DAC existing in 1973 and the Soviet Bloc , Lundborg (1998) who analyzes the US and the Soviet Union, and Dreher et al. (2008), who investigates the G7 
countries, the aid donor country considered is the United States. Also, all of the previous research, with the exception of Dreher et al. (2008), considers aid in aggregate terms. However, it is not unreasonable to assume DAC countries have different end goals associated with their foreign aid (i.e. political versus humanitarian) and that disaggregated aid may change the overall understanding of how aid works in practice (Cassen 1986, Levy 1987, and White 1998), especially since the type of aid has changed over time (Thiele et al. 2007). Chapter 3 of this dissertation extends the previous literature on aid and voting influence by considering the foreign aid patterns of the 22 members of the DAC so as to account for the possible different end goals of each DAC country while Chapter 4 considers the heterogeneous nature of aid by disaggregating total bilateral aid and empirically testing whether the different types of aid affect voting coincidence in diverse ways. Chapters 3 and 4 also consider the possibility that the empirical results represent a lower bound of political influence because of free rider behavior.

\subsection{Politically Tied: Political Power and Aid Tying Practices in the Development Assistance Committee}

Aid tying, or the restrictions placed by aid donors on aid recipients for how aid may be used, is discouraged in the development community because it increases the cost of aid to the recipient by 15 to 30 percent (Jepma 1991). Despite the general agreement that aid tying is an inefficient manner in which to distribute aid, aid tying is still practiced by a majority of the large aid donors. By 1979, the first available year of aid tying statistics, aid tying was commonplace as 51.36 percent of ODA was tied among DAC countries. The situation improved over time with 44.74 percent tied in the 1980's, 26.02 percent tied in the 1990's, and 12.59 percent tied in the 2000 's. However, while the proportion of tied aid has decreased, the amount of real tied aid was 35 percent higher in 2009 than 1979 and has steadily increased since 2003. 
As noted in the literature, economic and political reasons exist for tying aid, though empirical work has shown that tying aid may not be the most effective manner to address these problems. Why then is aid still tied if it is a poor method of implementing aid donor preferences? Chapter 2 empirically tests whether institutional factors, such as the fragmentation of the executive power and the position of government vis-à-vis legislative composition within the donor countries' governments help explain why real levels of tied aid remain stubbornly above zero despite the push in the development community to eliminate the practice. Understanding how institutional factors change aid tying practices improves the awareness of the incentives aid donors face, thus helping the process of aligning aid recipient and aid donor incentives, making foreign aid more beneficial for all parties involved.

In order to explore this hypothesis, a variant of the models used in the literature exploring how fragmented political power affects fiscal policy as pioneered by Roubini and Sachs (1989a and 1989b) is employed. The basic specification takes the following form:

$$
\text { RTA }_{i, t}=\beta_{0}+\beta_{1} \text { RTA }_{i, t-1}+\beta_{2} \text { Growth }_{i, t}+\beta_{3} \text { Trade }_{i, t}+\beta_{4} \text { POL }_{i, t}+\varepsilon_{t}
$$

where $i$ and $t$ are the country and year indices, respectively. The dependent variable (RTA) represents total bilateral aid commitments tied. The explanatory variables are: the lagged tied aid $\left(\mathrm{RTA}_{\mathrm{t}-1}\right)$, the annual percentage growth of real GDP (Growth), trade as a percentage of GDP (Trade), and various political variables (POL). The paper uses a panel of 22 DAC countries from 1979 to 2009 . The model is estimated with country and time fixed effects.

The political variables are broken into two components: the impact of fragmentation of the executive power and the position of government vis-à-vis legislative composition. Three variables are used to measure the fragmentation of the executive power: the number of spending ministers and the simple and effective number of political parties with representation in the 
governing coalition. Three variables are also used to measure the position of government vis-àvis legislative composition: the excess number of seats held by the governing coalition and the simple and effective number of political parties with representation in government. These variables are designed to capture the varying types of political competition within government since different degrees of political competition affects the behavior of policy makers. For example, the impact of one coalition partner in a parliament is stronger if the support of the partner is needed to sustain enough support in parliament for the coalition to remain in power. The opposite also holds true: if the coalition controls substantially more seats in government then is needed for a simple majority, the power of any partner in the coalition is weaker since a coalition with excess partners has the ability to drop a partner and still remain in power (Laver and Schofield 1990).

Three types of robustness checks are also used. First, the sample period is divided into two time periods, 1979-1996 and 1997-2009, to check if the effects of political fragmentation change across time. The split was chosen to allow for the new norms and structures of foreign aid in the post Cold War to be firmly established. Second, the sensitivity of the full time period results for the sample of countries is also tested by re-estimating the models 22 times, excluding one country each time. Lastly, the annual data is converted into six 5 year averaged observations per country to analyze long term trends in changes to tied bilateral aid.

The results show, in regards to the fragmentation of the executive power, that the number of spending ministers is stronger and more robust than the simple and effect number of political parties in the governing coalition. The simple number of political parties in the governing coalition is significant in the full sample when all countries are considered, when the model is reestimated excluding one country at a time, and in the long term but is sensitive to different time 
periods considered. As for the position of government vis-à-vis legislative composition, the percentage of excess seats in parliament is significant in the full sample but is somewhat sensitive to the inclusion of countries in the sample. The number of political parties with representation in government is significant but sensitive to different time periods while there is some evidence that the effective number of political parties with representation is significant in the long term but is sensitive to different individual time periods considered.

\subsection{Exerting Political Influence: Does Foreign Aid of Development Assistance Committee Countries Influence Voting Coincidence}

While foreign aid is often given under the pretext of promoting economic growth and social development within the aid recipient country, the idea that donor countries would distribute foreign aid to advance their own agenda is not unthinkable. Bauer (1972) and Easterly (2006) detail how aid donors have used foreign aid to "plan" the economies of aid recipients and advance Western ideals. The official mission statement of USAID, the official development agency of the United States, admits that US foreign assistance has the "twofold purpose of furthering American's foreign policy interests in expanding democracy and free markets while improving the lives of the citizens of the developing world" (italics added). Australia's official development agency, AusAid, states the objective of their aid program is "to assist developing countries reduce poverty and achieve sustainable development, in line with Australia's national interest" (italics added).

The results of research exploring how effective foreign aid is in influencing donor and recipient voting habits in international bodies, particularly the United Nations, is concisely summarized by Dreher and Strum (2006) with the main findings showing the empirical evidence is inconclusive and mixed as to whether foreign aid increases voting coincidence. One major 
drawback of the previous research is that most studies focused exclusively on the United States and its relationship with aid recipients. This singular focus ignores the heterogeneity of interests other donor countries have in disbursing aid. Chapter 3 expands the previous research by considering all $22 \mathrm{DAC}$ countries and addresses the question of whether foreign aid donors use foreign aid disbursements to exert political influence by specifically analyzing whether foreign aid recipients vote more frequently in accordance with aid donors in the United Nations General Assembly roll call votes after having received foreign aid.

The model used is a variation of the models in the literature exploring foreign aid distribution and voting coincidence. The basic specification is of the following form:

$$
\mathrm{VC}_{\mathrm{i}, \mathrm{t}}=\beta_{0}+\beta_{1} \text { LevelODA }_{\mathrm{i}, \mathrm{t}-1}+\beta_{2} \text { Democracy }_{\mathrm{i}, \mathrm{t}-1}+\beta_{3} \text { National Capability }_{\mathrm{i}, \mathrm{t}-1}+\dot{\varepsilon}
$$

where $i$ and $t$ are the country and year indices respectively. The dependent variable (VC) is a measure of voting coincidence in the UN General Assembly. The variable of interest (LevelODA) is the level of DAC country aid dependence and is measured by the annual amount of a DAC country's Official Development Assistance (ODA) as a proportion of the total aid received by the recipient country. The other explanatory variables in the basic model are a measurement of democracy from Cheibub, Gandhi, and Vreeland (2010) and a measurement of national capability, which is composite measure of hard power from the Correlates of War website. The paper employs a panel data set from 1991 to 2008 for the 22 DAC countries and 155 aid recipient countries. ${ }^{2}$ The paper focuses exclusively on the post Cold War era since the nature of foreign aid has changed with the defeat of communism towards a new focus on eliminating world poverty and achieving the Millennium Development Goals (MDGs).

Due to the possible endogenous nature of aid, multiple estimation techniques are employed. Regressions are first estimated using Ordinary Least Squares (OLS) for the Nordic

\footnotetext{
${ }^{2}$ Specifically, 22 data sets are used, one for each DAC country.
} 
countries of Denmark, the Netherlands, Norway, and Sweden, Two-Stage Least Squares (2SLS) for the non-Nordic countries, and the difference GMM estimation of Arellano and Bond (1991) for all countries. Following Kilby (2006) and Dreher et al. (2008), the 2SLS and GMM estimation uses "good donor" instruments for the aid variables of the non-Nordic countries as suggested by Fleck and Kilby (2006a and 2006b). The instruments used are the ODA variables of Denmark, the Netherlands, Norway, and Sweden because their aid should be correlated with the aid patterns of the other DAC countries since major donors focus on the same set of 'aid darlings' (Theile et al. 2007) and because their aid is not affected by the UN voting behavior of aid recipients (Stokke 1989, Alesina and Dollar 2000, and Gates and Hoeffler 2004).

The results of the basic model demonstrate that of the non-Nordic countries considered, Canada, France, Spain, and the United Kingdom exhibit a positive relationship between voting coincidence and foreign aid distribution while no conclusive link could be established for the largest aid donor, the United States. These results are robust to the inclusion of additional variables suggested in the literature to be possible determinants of voting coincidence. These include measures of economic power (GDP per capita and real GDP growth), dependence on foreign support (external debt), "hard" power (the percentage of the labor force who are armed service personnel), and international trade patterns (imports and exports).

The data was also converted into six 3 year averaged observations per country to analyze longer term trends in changes to voting coincidence. The results of the basic model confirm the positive relationship between voting coincidence and foreign aid distribution for Canada, France, Spain, and the United Kingdom. They also show some different results: Belgium, Ireland, New Zealand, Portugal, and the United States have positive coefficients on the variable of interest while the negative coefficients on the variable of interest for Finland and Italy turn statistically 
insignificant. Factor analysis was also employed to analyze the relationships between voting patterns of the DAC countries and to investigate whether there is support for the regression results to be interpreted as a lower bound for political influence.

\subsection{Disaggregated Foreign Aid and Voting Coincidence in the Development Assistance Committee}

Chapter 4 extends the empirical analysis of chapter 3 by considering disaggregated bilateral aid instead of total bilateral aid and applying the analysis to all 22 DAC countries. Disaggregated bilateral aid is used for an assortment of reasons. First, different categories and types of aid may react singularly to varying conditions in recipient countries (Mavrotas and Ouattara 2006).

Second, donors pursue multiple objectives when granting aid causing these specific purposes to be obfuscated in aggregate totals (Isenman and Ehrenpreis 2003) and using total aid may result in aggregation bias that may blur empirical results because different aid categories exert different macroeconomic effects and because donor and recipient countries attach different utility to each category of aid (Mavrotas and Nunnenkamp 2007). Lastly, the composition of aid has changed over time (Theile et al. 2007) meaning some forms of aid are becoming more important while others are becoming less influential.

The most important contribution of this chapter compared to previous research is the inclusion of humanitarian aid in the empirical analysis. Humanitarian aid is becoming an increasingly important category of aid (Cassen 1994 and Addison 2000) yet previous research does not consider its effect because it is assumed humanitarian aid is not political in nature. However, there are recent empirical studies that provide evidence that humanitarian aid is deeply affected by political motivations (Garret and Sobel 2003, Sobel and Leeson 2006, and Escaleras et al. 2007) and therefore should be considered in analyses of political support. 
The basic model used is the same as in Chapter 3. A panel is constructed for each of the 22 DAC countries with the same 155 recipient countries from 1991 to 2007 . Regressions are estimated using the system GMM estimation of Arellano and Bond (1991) and the results of the system GMM estimation are based on the two-step estimator implemented by Roodman (2006), including the Windmeijer (2005) finite-sample corrected two-step covariance matrix to correct for downward bias in the standard errors. The same "good donor" instruments from Chapter 3 are used except that they are disaggregated. However, two lags of the dependent variable are included to model dynamics of the model instead of one lag because the Hansen $\mathrm{J}$ test does not reject the instruments at conventional levels of significance (in most cases) when both lags are included but does when only one lag is included.

Total bilateral aid is disaggregated into loans and grants and project, program and humanitarian aid. Program aid is then further divided into budget aid, food aid, and debt relief. Project aid includes aid for social infrastructure and services, economic infrastructure and services, production sectors, multi-sector aid, and support to non-governmental organizations (NGO's). Program aid includes commodity aid/general program assistance and action relating to debt. Humanitarian aid includes the sub-categories of emergency response, reconstruction relief and rehabilitation, and disaster prevention and preparedness.

Four main conclusions can be drawn from the results. First, not including humanitarian aid may result in the loss of important information and should be included. Second, the results are sensitive to recipient country inclusion and the inclusion of additional explanatory variables. Third, except for budget support, there is not a strong statistical relationship between disaggregated aid categories of the United States, the largest aid donor, and increased voting coincidence. Finally, these results provide some evidence that in the post Cold War era 
disaggregated aid measures do not show a robust influence on voting coincidence for most of the DAC countries. These results could differ from the results in chapter 3 because aid recipients may be more interested in the total value of aid rather than individual aid categories because of the fungibility of aid.

\subsection{Conclusion}

The final chapter of the dissertation summarizes the major findings of each of the research chapters, discusses their relevance to the current literature in the economics of foreign aid, and provides suggestions for future research extensions. 


\section{Chapter 2}

\section{Political Power and Aid Tying Practices in the Development Assistance Committee Countries}

\subsection{Introduction}

While foreign aid is often given under the pretext of promoting economic growth and social development, it has always contained a political nature (Morgenthau 1962, O’Leary 1967, and Nelson 1968) with domestic policies in donor countries shaping foreign aid allocations (Leogrande and Brenner 1993, Therien and Noel 2000, Fleck and Kilby 2001, and Otter 2003). During the Cold War, foreign aid was distributed by Western powers to expand Western influence (Schraeder et al. 1998). Since the end of the Cold War, foreign aid has changed to helping transition economies (Boschini and Olofsgard 2001), fighting terrorism (Harrigan et al. 2006), and supporting other foreign policy objectives (Zimmerman 1993 and Ruttan 1996).

Another area where politics and foreign aid intersect is aid tying. The practice of aid tying, or the restrictions placed by aid donors on aid recipients for how aid may be used, was criticized in the aid community as early as the 1969 Pearson Commission, which investigated the effectiveness of the World Bank's development assistance. ${ }^{3}$ Among other recommendations, the report condemned aid tying since it reduced the overall value of aid by constraining recipient governments' abilities to direct aid where it was most beneficial. Despite the condemnation, by 1979 the practice of aid tying became abeunt studia in mores as 51.36 percent of Official Development Assistance (ODA) was tied among Development Assistance Committee (DAC)

\footnotetext{
${ }^{3}$ Three forms of aid tying exist: tying to specific projects or programs, tying of specific commodities or services being procured, and tying to the country or region where the procurements by the recipient country can take place (Jepma 1991). Officially, tied aid credits are defined as "official or officially supported loans, credits, or associated financing packages where procurement of the goods or services involved is limited to the donor country or to a group of countries which does not include substantially all developing countries" (italics added).
} 
members. ${ }^{4}$ While the proportion of tied aid has decreased over time (see Figure 2.1$)^{5}$, the amount of tied aid was 35 percent higher in 2009 than 1979 and has steadily increased since 2003, the lowest recorded level at $\$ 2.35$ billion. The latest increases continue even after the 2005 Paris Declaration on Aid Effectiveness called for the ending of tied aid.

Figure 2.1: Total Amount and Percentage of Tied Aid of Development Assistance Committee: 1979-2009

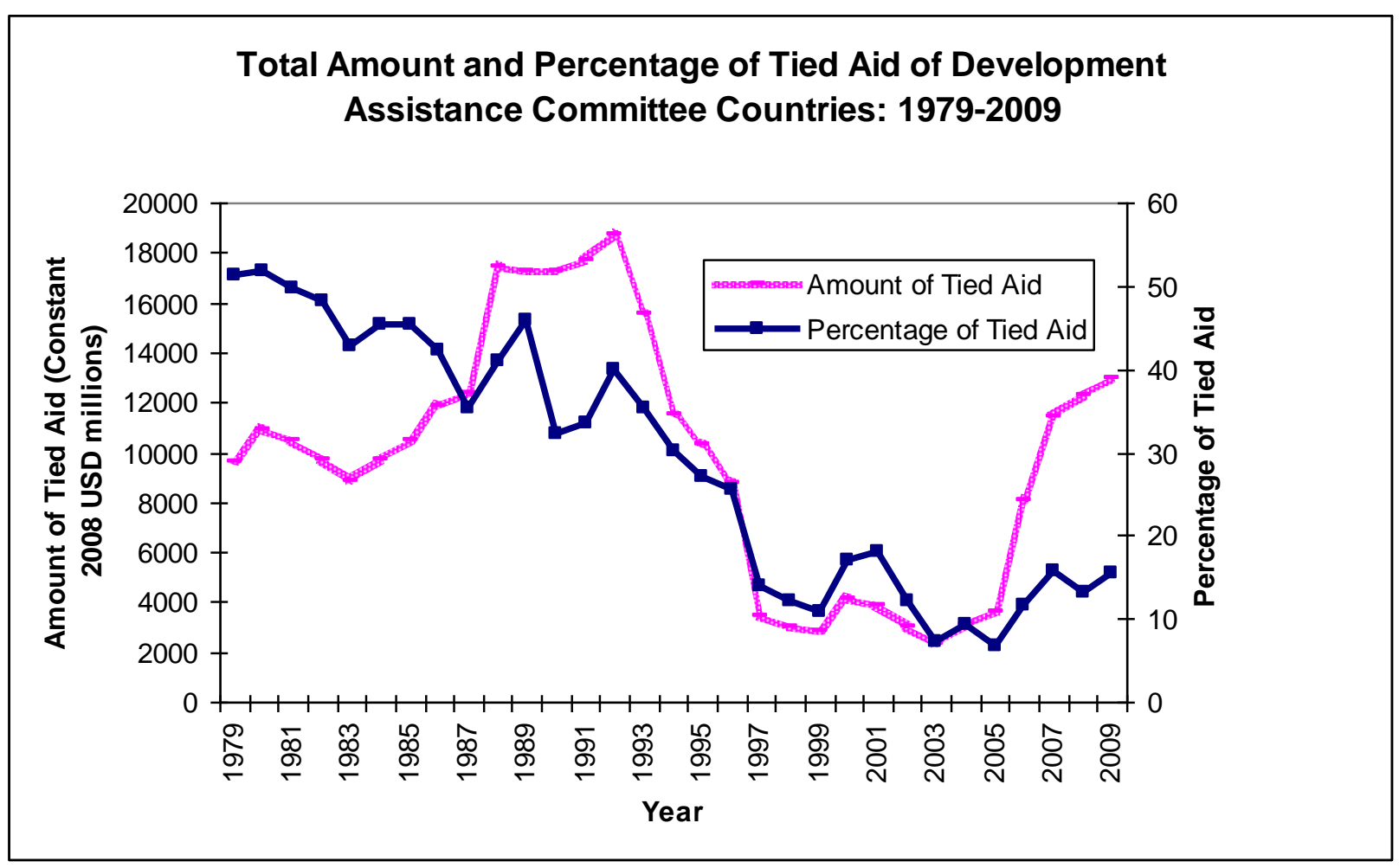

While determinants of bilateral aid allocations (Trumbull and Wall 1994) and the political nature of development assistance are explored in the foreign aid literature, to date no research has explored institutional factors for why real levels of tied aid remain stubbornly above zero despite the push in the development community to untie all ODA. This paper fills the gap in

\footnotetext{
${ }^{4} \mathrm{DAC}$ countries are used in the analysis because the OECD considers them to have major foreign aid programs and they are the primary donors of ODA (since 1960 they have given 74.5 percent of worldwide ODA).

5 The percentage of tied aid has fallen each decade (44.74 percent in the 1980's, 26.02 percent in the 1990's, and 12.59 percent in the 2000's) although it has been relatively flat since 1997 and has generally increased since 2005.
} 
the literature by empirically testing whether institutional factors such as fragmentation of the executive power and the position of government vis-à-vis legislative composition within the governments of donor countries help explain this phenomenon. Aid recipients and aid donors face different and sometimes conflicting incentives when giving and receiving aid; aid recipients have incentives to receive untied aid while aid donors have incentives to give tied aid.

Understanding how institutional factors affect donor countries' aid tying practices improves the understanding of the incentives aid donors face, thus helping the process of aligning aid recipient and aid donor incentives, making foreign aid more beneficial for all parties involved.

Aid tying is a form of protectionism that gives donors the tendency to focus on their own commercial self-advancement instead of the needs of the aid recipient (Quartey 2005). Commercial reasons for tying aid include: stimulating employment, bolstering exports ${ }^{6}$, improving the balance of payments, and strengthening individual sectors in the aid donor country. Political reasons for aid tying include: satisfying strong lobbying groups (Lahiri and Raimondos-Moller 2000) and reforming the internal governing of the aid recipient countries (World Bank 1998, Woods 2000 and Hermes and Lensink 2001). The effectiveness of aid conditionality, of which aid tying is a form, in implementing the aid donor's preferences is debatable (see White and Morrissey 1997, Maxwell and Riddell 1998, Leandro et al. 1999, Wood and Lockwood 1999, and Villanger 2004) ${ }^{7}$ but empirical evidence suggests aid is given irrespective of how well the recipient country is in following the donor's stipulations (Mosley et al. 1995, Collier 1997, and Svensson 2000).

\footnotetext{
${ }^{6}$ However, Tajoli (1999) finds that tied aid does not generate aid flows as aid donor's export shares are not correlated to the degree of aid tying.

${ }^{7}$ Chapter 3 shows that of the 12 DAC countries with a higher average percentage of tied aid than the DAC average, only four (Canada, France, Spain, and the United Kingdom) show a robust positive relationship between voting coincidence in the United Nations General Assembly and foreign aid distribution while Belgium, New Zealand, and the United States show a positive relationship in only certain model specifications.
} 
What is less debatable is how tied aid reduces the opportunity for aid recipient countries to "shop around" for the most suitable goods and services and raises the direct costs to the aid recipient an average of 15 to 30 percent (Jepma 1991). Baffour (2004) finds a significant markup on the prices of tied aid imports compared to the prices of non-aid imports. Aryeetey, Osei, and Quartey (2003) show aid-funded projects to Ghana would have had a greater impact if donor conditionality was not attached since sending expatriates to aid-receiving countries, as a form of tied technical assistance, undermines local institutional capacity. However, Aryeetey (1995) and Sowa and White (1997) argue if tied aid is "well designed and effectively managed," the quality and effectiveness of the aid is not necessarily compromised.

This paper proceeds as follows. Section two presents a literature review of the theoretical framework for empirical analysis. Section three describes the data and introduces the empirical specifications. Section four shows the basic econometric results and provides interpretation. Section five conducts some sensitivity analyses and section six tenders concluding remarks.

\subsection{Literature Review}

While donor intention and its connection to foreign aid flows is fairly represented in the foreign aid literature, an area receiving much less attention is the internal structure of the donor country government and its effect on foreign aid. ${ }^{8}$ Most DAC countries are parliamentary democracies with varying degrees of political power dispersion and size fragmentation in their governing coalition. Different size governing coalitions confront diverse political incentives and may behave accordingly. For example a single party majority government has considerably more

\footnotetext{
${ }^{8}$ Two notable exceptions are Therien (2002) and Fleck and Kilby (2006). Therien (2002) finds development assistance priorities differ depending on the ideology of the political party in power. Fleck and Kilby (2006) show development assistance in the United States under liberal regimes mirrors a humanitarian approach while conservative regimes adopt a more commercial approach.
} 
strength to pursue a wider variety of policies than a minority government which is always in danger of a vote of no confidence and loss of power.

The 'common pool problem' of Weingast et al. (1981) and Shepsle and Weingast (1981) describing the relationship between the number of decision makers and government expenditures illustrates the theoretical intuition of the current study. Individual groups, and indirectly those who represent their interests in formulating public policy, benefit from targeted expenditures while the costs of those expenditures fall on a widespread population. ${ }^{9}$ Whereas the individual groups fully internalize the benefits of the expenditures, they only internalize a fraction of $1 / n$ of the costs. The fraction of the cost internalized falls as the number $n$ of groups and their representatives increases so that the larger number of actors in the process leads to increased expenditures. $^{10}$

While the intuition is straightforward, empirical testing of the hypothesis can follow several interpretations depending on the basic decision making unit chosen. This study follows the basic interpretations of the political competition literature (see below), including the extensions of Perotti and Kontopoulos (1999) and Volkerink and De Haan (2001) who consider the fragmentation of the executive power and the government's position vis-à-vis legislative composition respectively. These variables are described in section three.

\footnotetext{
${ }^{9}$ Examples of tied aid include French technical assistance programs where only French professionals are sent as advisors and US food aid, of which 75 percent must be shipped on US flagged vessels. Even when aid is untied, donor countries take steps to secure aid money is spent at home. For example, in Germany tenders fewer than 200,000 euros are not advertised and those over 200,000 euros are only advertised in German speaking newspapers (Action Aid International 2005).

${ }^{10}$ Since foreign aid contracts are often awarded by donor country aid organizations, business and interest groups have incentive to lobby for these profitable opportunities. Examples include Swedish exporters asking for more private sector involvement in the disbursement of Swedish foreign aid (ActionAid International 2005) and Archer Daniels Midland Corporation, an agribusiness company, lobbing against cuts in US foreign aid (Morgan 1995). Sometimes even policymakers lobby on behalf of companies, such as Alabama Senator Jeff Sessions pressing USAID, the United States development agency, to order condoms from for Alatech Healthcare, an Alabama condom maker.
} 
The political economy literature has two distinct strands in how political competition works. One strand finds political competition increases the public sector's efficiency (Stigler 1972, Wittman 1989, Rogers and Rogers 2000, Padovano and Ricciuti 2009, and Besley et al. 2010). The second strand argues political competition leads to inefficiency in the public sector which causes greater public sector expenditures, deficits, and debts (Roubini and Sachs 1989a and 1989b, De Haan and Sturm 1994, Perotti and Kontopoulos 1999, Volkerink and De Haan 2001, and Huber et al. 2003). This second strand focuses on political competition through the fragmentation of the executive power and the government's position vis-à-vis legislative composition and is most relevant for the current study.

\subsection{Data and Estimation}

\subsubsection{Descriptions of data and variables}

The paper uses a panel of 22 DAC countries from 1979 to 2009. Data is not available for each variable in every year, creating an unbalanced panel and the number of observations in each regression depends on the choice of explanatory variables. A detailed data description and sources for all variables used in the empirical analysis are provided in Appendix 2A. Since some of the political variables are measuring similar relationships, a correlation matrix is provided in Appendix 2B along with the summary statistics in Appendix 2C.

The model used is a variant of the models used in the literature exploring how fragmented political power affects fiscal policy as pioneered by Roubini and Sachs (1989a and 1989b). The basic specification is of the following form:

$$
\text { RTA }_{i, t}=\beta_{0}+\beta_{1} \text { RTA }_{i, t-1}+\beta_{2} \text { Growth }_{i, t}+\beta_{3} \text { Trade }_{i, t}+\beta_{4} \text { POL }_{i, t}+\varepsilon_{t}
$$


where $i$ and $t$ are the country and year indices, respectively. The dependent variable (RTA) represents total bilateral aid commitments tied. ${ }^{11}$ The explanatory variables are: lagged tied bilateral aid $\left(\mathrm{RTA}_{\mathrm{t}-1}\right)$, the annual percentage growth of real GDP (Growth), trade as a percentage of GDP (Trade), various political variables (Pol) defined below, and the error term. ${ }^{12}$

Economic growth and the trade variable measuring international openness are included as measurements capturing the reaction function (behavior) of policymakers. As discussed by Jepma (1991), one of the justifications for tying development assistance is to bolster the economic outcomes of donor countries. Policymakers, especially in difficult economic times, have incentives to pursue policies designed to increase GDP, though it is empirically unclear if tying aid accomplishes such goals. International openness may affect the behaviors of donor countries towards recipient countries. A donor country that is generally more open may encourage less aid tying because it violates their principles of globalization or because increased international competition for development assistance spending will possibly increase their exports. Conversely, a donor country that is generally more closed may encourage aid tying because it protects the interests of the donor country, perhaps protecting a politically powerful interest group within the donor country.

The political variables are broken into two groups. First, the paper examines the impact of fragmentation of the executive power. Then, the position of government vis-à-vis legislative composition is analyzed.

\footnotetext{
${ }^{11}$ Official development assistance is given bilaterally and multilaterally. Since aid is fungible (see Denger and Sen 1991, Pack and Pack 1993, Boone 1996, and McGillivray and Morrissey 2000), multilateral aid is difficult to tie. Since bilateral aid is easier to control from the donor perspective, this paper focuses on bilateral ODA.

${ }^{12}$ Following Perotti and Kontopoulos (1999) and Volkerink and De Haan (2001), additional explanatory variables were tried. These included the inflation and the unemployment rates. These were generally insignificant and their presence did not affect the standard results.
} 
Fragmentation of the executive power is often interpreted in the literature as the number of decision makers. One interpretation of the number of decision makers is the number of spending (cabinet) ministers (NSM), whose constituencies are interest groups and industries who benefit directly from budget expenditures, and who act as individual units with their own influence and demands on the formulation of the overall budget process. Following Volkerink and De Haan (2001), NSM is calculated as the number of full ministers (not counting Ministers of State or Junior Ministers) in government at the end of each year but does not include the ministers of finance/budget or prime ministers because in theory they represent the "average" taxpayer instead of individual groups (Alesina and Perotti 1999). ${ }^{13}$

An alternate interpretation is that the number of decision makers corresponds to the number of political parties represented in the governing coalition since political parties are cohesive units representing the interests of specific groups. Two variables are used. The first is a count of the number of political parties with representation in the governing coalition (NPC). However, since NPC does not consider the size of the various political parties a third variable, the effective number of political parties in the governing coalition (ENPG) as advanced by Volkerink and De Haan (2001) is employed. This variable is defined as:

$$
\mathrm{ENPG}=1 / \sum_{i=1}^{n} p_{\mathrm{i}}^{2}
$$

where $\mathrm{p}_{\mathrm{i}}$ denotes the share of ministers from party $i$ as a proportion of the total number of ministers and $n$ is the number of coalition parties. This is the inverse of the Herfindahl index measuring the amount of competition within the governing coalition.

The position of government vis-à-vis legislative composition can also be measured in different manners. The impact of one coalition partner is stronger if the support of the partner is

\footnotetext{
${ }^{13}$ The author used Woldendorp, Keman, and Budge (1998) as a guide. However since all the political variables can change during the same governing coalition, the author calculated the political variables per year as opposed to per coalition leading to different numbers from Woldendorp, Keman, and Budge.
} 
needed to sustain enough support in parliament for the coalition to stay in power. The opposite also holds true: if the coalition controls substantially more seats in government then is needed for a simple majority, the power of any partner in the coalition is weaker since a coalition with excess partners has the ability to drop a partner and continue to remain in power (Laver and Schofield 1990). The ability to remove a coalition partner and still remain in power also reduces the pressure of satisfying the interest groups represented by each coalition partner which may lead to less special interest spending or protection. However, as the number of coalition partners increases, the power of each interest group represented is weakened and reduces their influence. Therefore, three variables are considered. The first variable is the excess number of seats (ES) held by the governing coalition. ${ }^{14}$ The variable is defined as:

$$
\mathrm{ES}=(\# \text { of seats above simple majority }) /(\text { simple majority })
$$

The second variable is the number of political parties with representation in government (NPP). Like NPC, NPP does not consider the size of the various parties in the governing coalition so the effective number of parties in the legislative branch (ENPP) is used. The variable is defined as:

$$
\mathrm{ENPP}=1 / \sum_{i=1}^{n} p_{\mathrm{i}}^{2}
$$

where $\mathrm{p}_{\mathrm{i}}$ denotes the share of ministers from party $i$ as a proportion of the total number of ministers and $n$ is the number of parties holding representation in the legislative branch. Like ENPG, this variable is the inverse of the Herfindahl index measuring the amount of competition with the legislative branch of government.

\subsubsection{Methodology}

The data is estimated with fixed country and time effects (not shown for reasons of space) as specified by the Hausman test to partial out common shocks that may not be adequately

\footnotetext{
${ }^{14} \mathrm{ES}$ is not collected for the United States because the bicameral system makes it difficult to determine the excess number of seats if the two legislative chambers are controlled by two different parties.
} 
captured by the control variables. In some specifications, a lagged dependent variable is used to model the dynamics of the model since fixed effects' models only estimate short-run effects because they are based on the time series component of the data. However, using the standard Least Squares Dummy Variable (LSDV) with a lagged dependent variable generates biased estimates of order $\mathrm{O}(1 / \mathrm{T})$ as $N \rightarrow \infty$ if the number of time periods $T$ is kept fixed since $\mathrm{y}_{\mathrm{it}-1}$ will still be correlated with the error term $u_{i t}$ (Nickell 1981). The question is whether this dynamic bias presents estimation problems and what size $T$ is needed before the dynamic bias can be ignored.

In large $T$ panels a shock to the country's fixed effect, which is captured in the error term, declines with time and becomes insignificant while the correlation of the lagged dependent variable with the error term becomes insignificant making dynamic bias less of a problem (Roodman 2006). Roodman advises that estimation techniques designed for dynamic panel bias should only be used for small $T$ and large $N$ panels since a more straightforward LSDV estimator works better because the number of instruments needed for dynamic bias correction explodes with $T$ and if $N$ is relatively small the cluster-robust standard errors and the Arellano-Bond autocorrelation test may be unreliable. Attanasio, Picci, and Scorcu (2000) and Baltagi, Griffin, and Xiong (2000) argue with a large enough $T$ the bias created by using LSDV is more than offset by its greater precision and efficiency gains of pooling the data when compared to other estimation techniques. Judson and Owen (1999) conclude a panel with $T \geq 30$ should use LSDV because it performs just as well or better than the viable estimation alternatives and the small bias would still result in an estimate with the correct sign. Since this paper has $T=31$, this paper chooses to use LSDV estimation because the small bias that comes with an OLS estimator of a dynamic model is preferred to the loss of precision of other estimating techniques and the small 
bias that may be present will not be large enough to change the signs of the coefficients. The estimation also uses standard errors adjusting for heteroskedasticity of an unknown order and within cluster autocorrelation to reduce idiosyncratic disturbances across countries through time.

\subsection{Results for the basic model}

Following previous literature where the effects of fragmentation of the executive power and the government's position vis-à-vis legislative composition are estimated separately, this paper proceeds in the same manner. ${ }^{15}$ The first model analyzes fragmentation of the executive power (Table 2.1). Columns 1 and 2 include NPC but not the interaction terms. ${ }^{16}$ NSM and NPC are statistically significant at the 1 and 10 percent level respectively when LRTA is not included. When LRTA is included, NSM and NPC are statistically significant at the 10 and 5 percent level respectively. One additional spending minister increases tied bilateral aid between $\$ 44.30$ million (when LRTA is included) and $\$ 133.53$ million (when LRTA is not included), a 4.7 to 14.25 percent increase from the mean value of tied bilateral aid. An additional political party in the governing coalition increases tied bilateral aid between $\$ 42.48$ million (when LRTA is included) and \$159.16 million (when LRTA is not included), a 4.5 to 16.9 percent increase.

Columns 3 and 4 contain ENPG but not the interaction terms. NSM is statistically significant at the 1 percent level when LRTA is not included and at the 10 percent level when LRTA is included. One additional spending minister increases tied bilateral aid between $\$ 46.30$ million (when LRTA is included) and \$139.29 million (when LRTA is not included), a 4.9 to 14.8 percent increase. ENPG is not statistically significant.

\footnotetext{
${ }^{15}$ Please see Appendix 2D for the results of the standard model when all political variables are included in the same regression.

${ }^{16}$ Perotti and Kontopoulos (1999) argue governments with different political or institutional characteristics react differently to changes in economic variables. Therefore the political variables are interacted with economic growth.
} 
Table 2.1: The impact of size fragmentation on tied aid (Full Sample)

\begin{tabular}{|c|c|c|c|c|c|c|c|c|}
\hline Variable & 1 & 2 & 3 & 4 & 5 & 6 & 7 & 8 \\
\hline $\begin{array}{c}\text { Total Bilateral Aid Commitments } \\
\text { Tied (t-1) }\end{array}$ & & $\begin{array}{c}0.74 \\
(0.09)^{* * *}\end{array}$ & & $\begin{array}{c}0.75 \\
(0.09)^{* * *}\end{array}$ & & $\begin{array}{c}0.74 \\
(0.09)^{* * * *}\end{array}$ & & $\begin{array}{c}0.75 \\
(0.10)^{* * * *}\end{array}$ \\
\hline No. of Spending Ministers & $\begin{array}{c}133.53 \\
(48.14)^{* * *}\end{array}$ & $\begin{array}{l}44.30 \\
(21.99)^{*}\end{array}$ & $\begin{array}{c}139.29 \\
(50.22)^{* * *}\end{array}$ & $\begin{array}{c}46.30 \\
(23.85)^{*}\end{array}$ & $\begin{array}{c}120.49 \\
(51.36) * *\end{array}$ & $\begin{array}{c}36.04 \\
(22.39)\end{array}$ & $\begin{array}{c}125.90 \\
(52.75) * *\end{array}$ & $\begin{array}{c}38.79 \\
(23.82)\end{array}$ \\
\hline $\begin{array}{l}\text { No. of Political Parties in Gov. } \\
\text { Coalition }\end{array}$ & $\begin{array}{c}159.16 \\
(80.97)^{*}\end{array}$ & $\begin{array}{c}42.28 \\
(20.50)^{* *}\end{array}$ & & & $\begin{array}{l}145.46 \\
(92.30)\end{array}$ & $\begin{array}{c}34.06 \\
(27.01)\end{array}$ & & \\
\hline $\begin{array}{l}\text { Effective No. of Political Parties } \\
\text { in Gov. Coalition }\end{array}$ & & & $\begin{array}{c}115.26 \\
(132.75)\end{array}$ & $\begin{array}{c}-5.14 \\
(33.72)\end{array}$ & & & $\begin{array}{c}85.41 \\
(143.45)\end{array}$ & $\begin{array}{c}-4.66 \\
(46.78)\end{array}$ \\
\hline Growth & $\begin{array}{c}17.6 \\
(36.09)\end{array}$ & $\begin{array}{c}33.66 \\
(13.94)^{* *}\end{array}$ & $\begin{array}{c}13.19 \\
(36.41)\end{array}$ & $\begin{array}{c}32.54 \\
(13.43)^{* *}\end{array}$ & $\begin{array}{l}-75.96 \\
(59.00)\end{array}$ & $\begin{array}{l}-27.08 \\
(28.34)\end{array}$ & $\begin{array}{c}-96.93 \\
(45.40)^{* *}\end{array}$ & $\begin{array}{l}-11.99 \\
(33.03)\end{array}$ \\
\hline Trade & $\begin{array}{c}10.12 \\
(10.08)\end{array}$ & $\begin{array}{l}-0.09 \\
(3.64)\end{array}$ & $\begin{array}{c}9.56 \\
(10.93)\end{array}$ & $\begin{array}{l}-0.47 \\
(3.87)\end{array}$ & $\begin{array}{c}10.34 \\
(10.09)\end{array}$ & $\begin{array}{l}-0.16 \\
(3.67)\end{array}$ & $\begin{array}{c}9.86 \\
(10.88)\end{array}$ & $\begin{array}{l}-0.63 \\
(3.84)\end{array}$ \\
\hline $\begin{array}{l}\text { No. of Spending Ministers } \mathrm{x} \\
\text { Growth }\end{array}$ & & & & & $\begin{array}{c}4.71 \\
(1.90)^{* *}\end{array}$ & $\begin{array}{c}3.11 \\
(1.15)^{* * * *}\end{array}$ & $\begin{array}{c}4.92 \\
(1.85)^{* *}\end{array}$ & $\begin{array}{c}2.63 \\
(1.21)^{* *}\end{array}$ \\
\hline $\begin{array}{l}\text { No. of Political Parties in Gov. } \\
\text { Coalition x Growth }\end{array}$ & & & & & $\begin{array}{c}7.38 \\
(10.92)\end{array}$ & $\begin{array}{c}4.48 \\
(5.33)\end{array}$ & & \\
\hline $\begin{array}{l}\text { Effective No. of Political Parties } \\
\text { in Gov. Coalition x Growth }\end{array}$ & & & & & & & $\begin{array}{c}16.49 \\
(17.17)\end{array}$ & $\begin{array}{c}1.41 \\
(8.32)\end{array}$ \\
\hline Constant & $\begin{array}{l}-1340.6 \\
(860.53) \\
\end{array}$ & $\begin{array}{c}-473.27 \\
(254.60)^{*}\end{array}$ & $\begin{array}{l}-1247.01 \\
(906.80) \\
\end{array}$ & $\begin{array}{l}-374.65 \\
(299.09)\end{array}$ & $\begin{array}{r}-1097.39 \\
(911.47) \\
\end{array}$ & $\begin{array}{l}-316.35 \\
(240.92)\end{array}$ & $\begin{array}{l}-989.15 \\
(927.50) \\
\end{array}$ & $\begin{array}{l}-243.06 \\
(279.82)\end{array}$ \\
\hline Number of countries & 22 & 22 & 22 & 22 & 22 & 22 & 22 & 22 \\
\hline Number of observations & 532 & 481 & 532 & 481 & 532 & 481 & 532 & 481 \\
\hline R-squared (within) & 0.35 & 0.73 & 0.34 & 0.73 & 0.36 & 0.74 & 0.34 & 0.73 \\
\hline
\end{tabular}

Standard errors in parentheses: $* * *=1 \%, * *=5 \%, *=10 \%$ significance level.

How should the signs of these coefficients be interpreted? Since a spending minister acts as an individual unit bringing their own demands or indirectly the demands of their own constituency (i.e. the Secretary of Agriculture representing agricultural interests) to the overall spending demands of the executive branch, a positive coefficient provides evidence that as the number of constituencies increases the more aid is tied to secure political support. Having a cohesive cabinet may be important in showing political strength to outsiders, providing incentives for the decision makers to find ways to keep support and increasing tied aid may be one way. The positive coefficient of NPC provides evidence a government with more 
constituencies ties more bilateral aid than a government with less constituency pressure as the government seeks to protect its political power. For some governing coalitions, a loss of a coalition partner means the difference for being in and out of power.

Columns 5-8 include the interaction terms with columns 5 and 6 including NSM and NPC while columns 7 and 8 include NSM and ENPG. ${ }^{17}$ When NSM and NPC are considered, NSM is statistically significant at the 5 percent level when LRTA is not included and at the 10 percent level when LRTA is included. NPC is statistically significant at the 10 percent level under both specifications. One additional spending minister increases tied bilateral aid between \$43.70 million (when LRTA is included) and \$132.12 million (when LRTA is not included), a 4.7 to 14.1 percent increase. An additional political party in the governing coalition increases tied bilateral aid between $\$ 45.13$ million (when LRTA is included) and $\$ 163.66$ million (when LRTA is not included), a 4.8 to 17.47 percent increase.

When NSM and ENPG are considered, NSM is statistically significant at the 1 percent level when LRTA is not included and at the 10 percent level when LRTA is included. One additional spending minister increases tied bilateral aid between $\$ 45.28$ million (when LRTA is included) and \$138.04 (when LRTA is not included), a 4.8 to 14.4 percent increase. Again ENPG is not statistically significant at conventional levels.

The second model analyzes the impact of the government's position vis-à-vis legislative composition on tied aid (Table 2.2).

\footnotetext{
${ }^{17}$ Interpreting the partial effect of a variable when it is included in an interaction term must be done with extreme care as the partial effect of a variable may be statistically significant even if the variable alone and the variable with the interaction term is statistically insignificant. Following Wooldridge (2006), this paper evaluates the political variables at the mean value of Growth, a more relevant value of Growth than zero.
} 
Table 2.2: The impact of the government's position vis-à-vis legislative composition on tied aid (Full Sample)

\begin{tabular}{|c|c|c|c|c|c|c|c|c|}
\hline Variable & 1 & 2 & 3 & 4 & 5 & 6 & 7 & 8 \\
\hline $\begin{array}{l}\text { Total Bilateral Aid Commitments } \\
\text { Tied (t-1) }\end{array}$ & & $\begin{array}{l}0.85 \\
(0.04)^{* * * *}\end{array}$ & & $\begin{array}{c}0.85 \\
(0.03)^{* * *}\end{array}$ & & $\begin{array}{c}0.85 \\
(0.04)^{* * *}\end{array}$ & & $\begin{array}{c}0.85 \\
(0.03) * * *\end{array}$ \\
\hline $\begin{array}{l}\text { Excess No. of Seats held by Gov. } \\
\text { Coalition }\end{array}$ & $\begin{array}{c}-7.66 \\
(4.49)^{*}\end{array}$ & $\begin{array}{c}-2.77 \\
(1.49)^{*}\end{array}$ & $\begin{array}{l}-3.88 \\
(3.04)\end{array}$ & $\begin{array}{c}-2.59 \\
(1.43)^{*}\end{array}$ & $\begin{array}{l}-6.55 \\
(4.01)\end{array}$ & $\begin{array}{l}-1.93 \\
(1.29)\end{array}$ & $\begin{array}{l}-2.51 \\
(3.10)\end{array}$ & $\begin{array}{l}-1.97 \\
(1.32)\end{array}$ \\
\hline $\begin{array}{l}\text { No. of Political Parties with } \\
\text { Representation in Gov. }\end{array}$ & $\begin{array}{l}-85.02 \\
(98.31)\end{array}$ & $\begin{array}{c}-5.29 \\
(11.49)\end{array}$ & & & $\begin{array}{c}-85.47 \\
(108.60)\end{array}$ & $\begin{array}{c}-8.80 \\
(13.89)\end{array}$ & & \\
\hline $\begin{array}{l}\text { Effective No. of Political Parties with } \\
\text { Representation in Gov. }\end{array}$ & & & $\begin{array}{c}318.32 \\
(136.10)^{* *}\end{array}$ & $\begin{array}{c}12.67 \\
(32.91)\end{array}$ & & & $\begin{array}{c}314.28 \\
(131.64)^{* *}\end{array}$ & $\begin{array}{c}17.24 \\
(35.13)\end{array}$ \\
\hline Growth & $\begin{array}{c}49.17 \\
(46.61)\end{array}$ & $\begin{array}{c}34.32 \\
(12.76)^{* *}\end{array}$ & $\begin{array}{c}35.54 \\
(48.21)\end{array}$ & $\begin{array}{c}12.42 \\
(2.72)^{* * *}\end{array}$ & $\begin{array}{c}51.02 \\
(81.61)\end{array}$ & $\begin{array}{c}23.07 \\
(24.85)\end{array}$ & $\begin{array}{c}31.40 \\
(59.80)\end{array}$ & $\begin{array}{c}45.68 \\
(16.35)^{* * * *}\end{array}$ \\
\hline Trade & $\begin{array}{c}7.75 \\
(10.04)\end{array}$ & $\begin{array}{c}1.33 \\
(2.45)\end{array}$ & $\begin{array}{c}9.25 \\
(10.76)\end{array}$ & $\begin{array}{c}1.44 \\
(2.35)\end{array}$ & $\begin{array}{c}7.82 \\
(10.14)\end{array}$ & $\begin{array}{c}1.34 \\
(2.44)\end{array}$ & $\begin{array}{c}9.37 \\
(10.87)\end{array}$ & $\begin{array}{c}1.42 \\
(2.38)\end{array}$ \\
\hline $\begin{array}{l}\text { Excess No. of Seats held by Gov. } \\
\text { Coalition x Growth }\end{array}$ & & & & & $\begin{array}{l}-45.74 \\
(67.67)\end{array}$ & $\begin{array}{l}-35.50 \\
(26.45)\end{array}$ & $\begin{array}{l}-56.98 \\
(64.65)\end{array}$ & $\begin{array}{l}-26.37 \\
(24.21)\end{array}$ \\
\hline $\begin{array}{l}\text { No. of Political Parties with } \\
\text { Representation in Gov. x Growth }\end{array}$ & & & & & $\begin{array}{c}0.34 \\
(7.38)\end{array}$ & $\begin{array}{c}2.02 \\
(3.40)\end{array}$ & & \\
\hline $\begin{array}{l}\text { Effective No. of Political Parties with } \\
\text { Representation in Gov. x Growth }\end{array}$ & & & & & & & $\begin{array}{c}2.65 \\
(8.90)\end{array}$ & $\begin{array}{l}-2.54 \\
(4.10)\end{array}$ \\
\hline Constant & $\begin{array}{l}1733.84 \\
(816.68) \\
\end{array}$ & $\begin{array}{c}182.81 \\
(363.08) \\
\end{array}$ & $\begin{array}{l}-145.72 \\
(876.84) \\
\end{array}$ & $\begin{array}{c}25.43 \\
(252.06) \\
\end{array}$ & $\begin{array}{c}1732.81 \\
(852.35)^{*}\end{array}$ & $\begin{array}{c}203.77 \\
(377.85) \\
\end{array}$ & $\begin{array}{l}-137.24 \\
(874.23) \\
\end{array}$ & $\begin{array}{c}67.60 \\
(379.90) \\
\end{array}$ \\
\hline Number of countries & 21 & 21 & 21 & 21 & 21 & 21 & 21 & 21 \\
\hline Number of observations & 511 & 463 & 511 & 463 & 511 & 463 & 511 & 463 \\
\hline R-squared (within) & 0.34 & 0.85 & 0.35 & 0.85 & 0.34 & 0.85 & 0.36 & 0.85 \\
\hline
\end{tabular}

Standard errors in parentheses: $* * *=1 \%, * *=5 \%, *=10 \%$ significance level.

Columns 1 and 2 include NPP but not the interaction terms. ES is statistically significant at the 10 percent level only when LRTA is included. An increase in the proportion of excess seats above the simple majority decreases tied bilateral aid between $\$ 2.77$ million (when LRTA is included) and \$7.66 million (when LRTA is not included), a 0.29 to 0.8 percent decrease. The negative coefficient of ES suggests that as the excess number of seats above the majority increases, a governing coalition can afford to "lose" some votes and still maintain its political power, reducing the incentive to "buy" votes through actions like aid tying. 
Columns 3 and 4 consider ENPP but not the interaction terms. ES is statistically significant at the 10 percent level only when LRTA is included while ENPP is statistically significant at the 5 percent level only when LRTA is not included. The magnitude of the coefficient for ES is similar to above as an increase in the proportion of excess seats above the majority decrease tied bilateral aid by $\$ 2.59$ million, a 0.27 percent decrease. An increase in the effective number of political parties in parliament increases tied bilateral aid by $\$ 318.32$ million, a 34 percent increase. The positive coefficient of ENPP provides evidence that as the number of meaningful political parties with representation in parliament increases, the governing coalition has the incentive to placate at least some of its political rivals' demands.

Columns 5-8 contain the interaction terms with columns 5 and 6 including ES and NPP while columns 7 and 8 include ES and ENPP. When ES and NPP are considered, ES is statistically significant at the 10 percent level with and without LRTA. The magnitudes are again similar to above as an increase in the proportion of excess seats above the majority decrease tied bilateral aid between $\$ 2.80$ million (when LRTA is included) and 7.68 million (when LRTA is not included), a 0.29 to 0.8 percent decrease. NPP is not statistically significant.

When ES and ENPP are considered, ES is statistically significant at the 10 percent level only when LRTA is included while ENPP is statistically significant at the 5 percent level only when LRTA is not included. An increase in the proportion of excess seats above the majority decreases tied bilateral aid by $\$ 2.62$ million, a 0.27 percent decrease. An increase in the effective number of political parties in parliament increases tied bilateral aid by $\$ 320.81$ million, a 34 percent increase. 


\subsection{Sensitivity Analyses}

This section contains various sensitivity tests. Following Perotti and Kontopoulos (1999) and Volkerink and De Haan (2001) who found the effect of political fragmentation on fiscal policy outcomes differs across time periods, this paper divides the sample set into two time periods, 1979-1996 and 1997-2009, to determine if the effects of political fragmentation on tied aid also changes across time. ${ }^{18}$ The ending of the Cold War may have been the biggest foreign policy change since WWII (Boschini and Olofsgard 2001) so this time split is chosen to allow for the new norms and structures of foreign aid in the post Cold War era to be firmly established. Meernik et al. (1998) and Boschini and Olofsgard (2001) note that while the ending of the Cold War substantially decreased the aggregate supply of development aid, the evolution of foreign policy goals of the new order was not completed immediately after the Cold War ended but instead evolved over a period of a few years during the mid 1990's. This phenomenon is seen in Figure 2.2, which shows aid during the Cold War peaked in 1991 (the unofficial end of the Cold War) and fell 18.7 percent by 1997. From 1997 to 2009, aid rose by 82 percent. The data indicate the year 1997 is the turning point where the unwinding of the Cold War foreign aid mentality was replaced with the new norms and structures of foreign aid in the post-Cold War era.

\footnotetext{
${ }^{18}$ The paper also splits the sample into a Cold War era (1979-1991) and a post Cold War era (1992-2009) and these results are available upon request.
} 


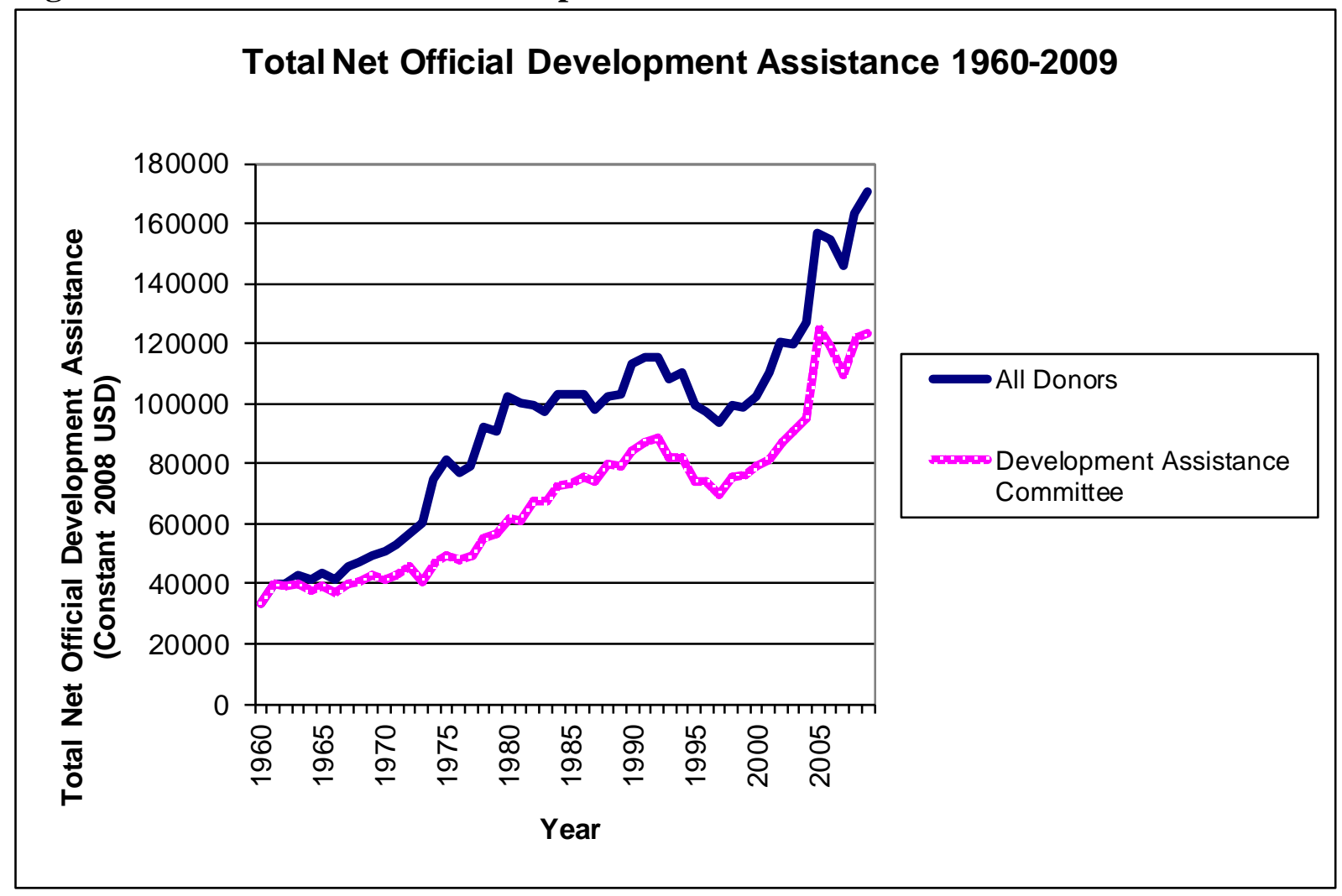

For each model, the lagged dependent variable is not included for two reasons. First, including the lagged dependent variable reduces the already small sample size. Second, and most importantly, when using appropriate estimation technique to correct for dynamic bias, the Sargan test rejects the validity of the instruments so the results cannot be trusted. It should also be noted that the absence of the lagged dependent variable lowers the overall fit of the model for each time period, especially 1997-2009, just like when it was absent in the full sample.

The first time period analyzed is the 1979-1996 period. In each of the models for both time periods columns 1 and 2 do not include the interaction term while columns 3 and 4 do. The first model analyzes fragmentation of the executive power (Table 2.3). When the interaction term is not included, only NSM is statistically significant at the 5 percent level. One additional spending minister increases tied aid between $\$ 103.88$ and $\$ 106.26$ million, a 7.07 to 7.23 percent 
increase. When the interaction term is included, only NSM is again statistically significant at the 5 percent level. One additional spending minister increases tied aid between $\$ 98.72$ and $\$ 101.32$ million, a 6.72 to 6.89 percent increase.

Table 2.3: The impact of size fragmentation on tied aid (1979-1996)

\begin{tabular}{|c|c|c|c|c|}
\hline Variable & 1 & 2 & 3 & 4 \\
\hline No. of Spending Ministers & $\begin{array}{c}103.88 \\
(50.14)^{* *}\end{array}$ & $\begin{array}{c}106.26 \\
(50.79) * *\end{array}$ & $\begin{array}{c}77.37 \\
(45.93)\end{array}$ & $\begin{array}{c}81.02 \\
(46.11)^{*}\end{array}$ \\
\hline $\begin{array}{l}\text { No. of Political Parties in Gov. } \\
\text { Coalition }\end{array}$ & $\begin{array}{l}-26.85 \\
(65.19)\end{array}$ & & $\begin{array}{l}-76.99 \\
(97.39)\end{array}$ & \\
\hline $\begin{array}{l}\text { Effective No. of Political Parties in } \\
\text { Gov. Coalition }\end{array}$ & & $\begin{array}{l}-90.19 \\
(60.20)\end{array}$ & & $\begin{array}{l}-152.3 \\
(90.89)\end{array}$ \\
\hline Growth & $\begin{array}{c}12.65 \\
(34.29)\end{array}$ & $\begin{array}{l}13.24 \\
(33.77)\end{array}$ & $\begin{array}{c}-179.52 \\
(63.03)^{* * *}\end{array}$ & $\begin{array}{c}-176.05 \\
(69.30)^{* * *}\end{array}$ \\
\hline Trade & $\begin{array}{l}-6.29 \\
(16.53)\end{array}$ & $\begin{array}{l}-5.79 \\
(16.67)\end{array}$ & $\begin{array}{c}-7.62 \\
(16.99)\end{array}$ & $\begin{array}{c}-7.79 \\
(17.27)\end{array}$ \\
\hline No. of Spending Ministers x Growth & & & $\begin{array}{c}8.40 \\
(3.53)^{* *}\end{array}$ & $\begin{array}{c}7.99 \\
(3.83)^{* *}\end{array}$ \\
\hline $\begin{array}{l}\text { No. of Political Parties in Gov. } \\
\text { Coalition x Growth }\end{array}$ & & & $\begin{array}{c}24.96 \\
(17.07)\end{array}$ & \\
\hline $\begin{array}{l}\text { Effective No. of Political Parties in } \\
\text { Gov. Coalition x Growth }\end{array}$ & & & & $\begin{array}{c}32.58 \\
(23.79)\end{array}$ \\
\hline Constant & $\begin{array}{c}-375.67 \\
(1203.98) \\
\end{array}$ & $\begin{array}{c}-334.85 \\
(1192.66)\end{array}$ & $\begin{array}{c}268.43 \\
(1122.61) \\
\end{array}$ & $\begin{array}{c}329.59 \\
(1083.41) \\
\end{array}$ \\
\hline Number of countries & 21 & 21 & 21 & 21 \\
\hline Number of observations & 288 & 288 & 288 & 288 \\
\hline R-squared (within) & 0.20 & 0.20 & 0.21 & 0.21 \\
\hline
\end{tabular}

Standard errors in parentheses: $* * *=1 \%, * *=5 \%, *=10 \%$ significance level.

The second model analyzes the impact of the government's position vis-à-vis legislative composition on tied aid (Table 2.4). When the interaction term is not included, NPP and ENPP are statistically significant at the 10 percent level. An additional party in parliament increases tied aid by $\$ 106.39$ million, a 7.24 percent increase while an increase in the effective number of political parties in parliament increases tied aid by $\$ 227.84$ million, a 15.51 percent increase. 
When the interaction term is included, NPP and ENPP are again statistically significant at the 10 percent level. An additional party in parliament increases tied aid by $\$ 103.96$ million, a 7.08 percent increase while an increase in the effective number of political parties in parliament increases tied aid by $\$ 236.58$ million, a 16.10 percent increase.

Table 2.4: The impact of the government's position vis-à-vis legislative composition on tied aid (1979-1996)

\begin{tabular}{|c|c|c|c|c|}
\hline Variable & 1 & 2 & 3 & 4 \\
\hline $\begin{array}{c}\text { Excess No. of Seats held by Gov. } \\
\text { Coalition }\end{array}$ & $\begin{array}{l}-5.94 \\
(4.97)\end{array}$ & $\begin{array}{l}-4.73 \\
(5.29)\end{array}$ & $\begin{array}{l}-5.87 \\
(5.18)\end{array}$ & $\begin{array}{l}-4.11 \\
(5.67)\end{array}$ \\
\hline $\begin{array}{l}\text { No. of Political Parties with } \\
\text { Representation in Gov. }\end{array}$ & $\begin{array}{c}106.39 \\
(52.85)^{*}\end{array}$ & & $\begin{array}{c}122.92 \\
(61.73)^{*}\end{array}$ & \\
\hline $\begin{array}{l}\text { Effective No. of Political Parties with } \\
\text { Representation in Gov. }\end{array}$ & & $\begin{array}{c}227.84 \\
(119.84)^{*}\end{array}$ & & $\begin{array}{c}205.22 \\
(107.78)^{*}\end{array}$ \\
\hline Growth & $\begin{array}{c}42.41 \\
(39.20)\end{array}$ & $\begin{array}{l}43.97 \\
(41.32)\end{array}$ & $\begin{array}{c}96.79 \\
(53.51)^{*}\end{array}$ & $\begin{array}{c}2.69 \\
(72.79)\end{array}$ \\
\hline Trade & $\begin{array}{l}-11.92 \\
(17.74)\end{array}$ & $\begin{array}{c}-9.93 \\
(17.33)\end{array}$ & $\begin{array}{l}-11.95 \\
(17.85)\end{array}$ & $\begin{array}{c}-9.57 \\
(17.33)\end{array}$ \\
\hline $\begin{array}{l}\text { Excess No. of Seats held by Gov. } \\
\text { Coalition x Growth }\end{array}$ & & & $\begin{array}{l}-0.04 \\
(0.73)\end{array}$ & $\begin{array}{l}-28.61 \\
(82.83)\end{array}$ \\
\hline $\begin{array}{c}\text { No. of Political Parties with } \\
\text { Representation in Gov. x Growth }\end{array}$ & & & $\begin{array}{l}-7.46 \\
(5.77)\end{array}$ & \\
\hline $\begin{array}{c}\text { Effective No. of Political Parties with } \\
\text { Representation in Gov. x Growth }\end{array}$ & & & & $\begin{array}{c}12.34 \\
(16.94)\end{array}$ \\
\hline Constant & $\begin{array}{c}541.19 \\
(1503.84) \\
\end{array}$ & $\begin{array}{c}336.32 \\
(1193.41) \\
\end{array}$ & $\begin{array}{c}424.99 \\
(1580.89) \\
\end{array}$ & $\begin{array}{c}411.93 \\
(1192.82) \\
\end{array}$ \\
\hline Number of countries & 20 & 20 & 20 & 20 \\
\hline Number of observations & 271 & 271 & 271 & 271 \\
\hline R-squared (within) & 0.24 & 0.23 & 0.24 & 0.23 \\
\hline
\end{tabular}

Standard errors in parentheses: $* * *=1 \%, * *=5 \%, *=10 \%$ significance level.

The second time period analyzed is the 1997-2009 period. The first model analyzes fragmentation of the executive power (Table 2.5). Like the 1979-1996 time period, only NSM is statistically significant (both when the interaction term is included and when it is not), though at 
the 10 percent level instead of the 5 percent level. When the interaction term is not included, one additional spending minister increases tied aid between $\$ 26.63$ and $\$ 26.93$ million, an 8.49 to 8.59 percent increase. When the interaction term is included, one additional spending minister increases tied aid between $\$ 25.07$ and $\$ 25.13$ million, a 7.99 to 8.01 percent increase.

Table 2.5: The impact of size fragmentation on tied aid (1997-2009)

\begin{tabular}{|c|c|c|c|c|}
\hline Variable & 1 & 2 & 3 & 4 \\
\hline No. of Spending Ministers & $\begin{array}{c}26.63 \\
(14.66)^{*}\end{array}$ & $\begin{array}{l}26.93 \\
(14.89)^{*}\end{array}$ & $\begin{array}{c}13.45 \\
(11.28)\end{array}$ & $\begin{array}{c}13.81 \\
(11.66)\end{array}$ \\
\hline $\begin{array}{l}\text { No. of Political Parties in Gov. } \\
\text { Coalition }\end{array}$ & $\begin{array}{l}-10.89 \\
(15.22)\end{array}$ & & $\begin{array}{l}-25.78 \\
(24.53)\end{array}$ & \\
\hline $\begin{array}{c}\text { Effective No. of Political Parties in } \\
\text { Gov. Coalition }\end{array}$ & & $\begin{array}{c}-3.80 \\
(29.05)\end{array}$ & & $\begin{array}{l}-17.99 \\
(40.09)\end{array}$ \\
\hline Growth & $\begin{array}{c}6.12 \\
(9.82)\end{array}$ & $\begin{array}{c}7.09 \\
(10.33)\end{array}$ & $\begin{array}{l}-87.39 \\
(51.52)\end{array}$ & $\begin{array}{l}-79.92 \\
(50.39)\end{array}$ \\
\hline Trade & $\begin{array}{l}-0.91 \\
(3.10)\end{array}$ & $\begin{array}{l}-0.98 \\
(3.19)\end{array}$ & $\begin{array}{l}-1.21 \\
(2.80)\end{array}$ & $\begin{array}{l}-1.38 \\
(2.99)\end{array}$ \\
\hline No. of Spending Ministers x Growth & & & $\begin{array}{c}4.94 \\
(2.61)^{*}\end{array}$ & $\begin{array}{c}4.76 \\
(2.57)^{*}\end{array}$ \\
\hline $\begin{array}{l}\text { No. of Political Parties in Gov. } \\
\text { Coalition x Growth }\end{array}$ & & & $\begin{array}{c}5.28 \\
(7.14)\end{array}$ & \\
\hline $\begin{array}{c}\text { Effective No. of Political Parties in } \\
\text { Gov. Coalition x Growth }\end{array}$ & & & & $\begin{array}{c}6.144 \\
(10.32)\end{array}$ \\
\hline Constant & $\begin{array}{r}92.68 \\
(454.14) \\
\end{array}$ & $\begin{array}{r}78.58 \\
(449.20) \\
\end{array}$ & $\begin{array}{r}355.54 \\
(354.13) \\
\end{array}$ & $\begin{array}{r}352.52 \\
(359.05) \\
\end{array}$ \\
\hline Number of countries & 22 & 22 & 22 & 22 \\
\hline Number of observations & 244 & 244 & 244 & 244 \\
\hline R-squared (within) & 0.07 & 0.07 & 0.09 & 0.09 \\
\hline
\end{tabular}

Standard errors in parentheses: $* * *=1 \%, * *=5 \%, *=10 \%$ significance level.

The second model analyzes the impact of the government's position vis-à-vis legislative composition on tied aid (Table 2.6). When the interaction term is not included, only NPP is statistically significant and only at the 10 percent level. One additional political party in parliament increases tied aid by $\$ 21.25$ million, a 6.78 percent increase. When the interaction 
term is included, NPP is statistically significant at the 10 percent level. One additional political party in parliament increases tied aid by $\$ 19.99$ million, a 6.37 percent increase.

Table 2.6: The impact of the government's position vis-à-vis legislative composition on tied aid (1997-2009)

\begin{tabular}{|c|c|c|c|c|}
\hline Variable & 1 & 2 & 3 & 4 \\
\hline $\begin{array}{l}\text { Excess No. of Seats held by Gov. } \\
\text { Coalition }\end{array}$ & $\begin{array}{l}-0.99 \\
(1.19)\end{array}$ & $\begin{array}{l}-7.69 \\
(1.10)\end{array}$ & $\begin{array}{l}-2.02 \\
(1.55)\end{array}$ & $\begin{array}{l}-0.81 \\
(1.35)\end{array}$ \\
\hline $\begin{array}{l}\text { No. of Political Parties with } \\
\text { Representation in Gov. }\end{array}$ & $\begin{array}{c}21.25 \\
(12.02)^{*}\end{array}$ & & $\begin{array}{c}40.5 \\
(14.53)^{* * *}\end{array}$ & \\
\hline $\begin{array}{c}\text { Effective No. of Political Parties with } \\
\text { Representation in Gov. }\end{array}$ & & $\begin{array}{l}11.57 \\
(34.06)\end{array}$ & & $\begin{array}{c}19.19 \\
(37.49)\end{array}$ \\
\hline Growth & $\begin{array}{c}1.75 \\
(8.37)\end{array}$ & $\begin{array}{l}0.28 \\
(7.43)\end{array}$ & $\begin{array}{c}64.04 \\
(28.01)^{* *}\end{array}$ & $\begin{array}{c}19.68 \\
(17.69)\end{array}$ \\
\hline Trade & $\begin{array}{l}-0.55 \\
(3.39)\end{array}$ & $\begin{array}{l}-0.73 \\
(3.59)\end{array}$ & $\begin{array}{l}-0.71 \\
(3.01)\end{array}$ & $\begin{array}{l}-0.96 \\
(3.47)\end{array}$ \\
\hline $\begin{array}{l}\text { Excess No. of Seats held by Gov. } \\
\text { Coalition x Growth }\end{array}$ & & & $\begin{array}{c}0.38 \\
(0.27)\end{array}$ & $\begin{array}{c}-0.68 \\
(20.65)\end{array}$ \\
\hline $\begin{array}{c}\text { No. of Political Parties with } \\
\text { Representation in Gov. x Growth }\end{array}$ & & & $\begin{array}{c}-8.67 \\
(4.02)^{* *}\end{array}$ & \\
\hline $\begin{array}{c}\text { Effective No. of Political Parties with } \\
\text { Representation in Gov. x Growth }\end{array}$ & & & & $\begin{array}{l}-5.09 \\
(4.89)\end{array}$ \\
\hline Constant & $\begin{array}{c}90.08 \\
(311.51)\end{array}$ & $\begin{array}{c}222.24 \\
(303.01)\end{array}$ & $\begin{array}{c}-76.08 \\
(310.25)\end{array}$ & $\begin{array}{c}209.06 \\
(314.95)\end{array}$ \\
\hline Number of countries & 21 & 21 & 21 & 21 \\
\hline Number of observations & 240 & 240 & 240 & 240 \\
\hline R-squared (within) & 0.10 & 0.04 & 0.11 & 0.05 \\
\hline
\end{tabular}

Standard errors in parentheses: $* * *=1 \%, * *=5 \%, *=10 \%$ significance level.

The sensitivity of the full time period results for the sample of countries is also tested.

The models were re-estimated 22 times, excluding one country every time. Some of the results, particularly those of ES, are sensitive for the inclusion of specific countries. When NPC and NPP are included in the specification, NPC is insignificant when France is dropped and ES is insignificant when Austria, France, or Japan is dropped whereas the results for NSM and NPP 
are unchanged. When ENPG and ENPP are incorporated, NSM and ENPP are insignificant when Italy is dropped and ES is insignificant when France, Germany, Italy, Japan, New Zealand, or Norway is dropped whereas the results of ENPG are unchanged.

Finally, the annual data is converted into six 5 year averaged observations per country (1979 is dropped) to analyze long term trends in changes to tied bilateral aid. Five year averages are used because averaging over the full sample "could result in a loss of temporal information, where the results would be driven solely by cross-country variations" (Grier 1997). The results confirm the basic results and show when NSM and NPC are included, NSM and NPC have positive coefficients and are significant at the 1 and 5 percent level respectively. When NSM and ENPG are included, NSM has a positive coefficient and is significant at the 1 percent level. When ES and NPP are included, ES has a negative coefficient and is statistically significant at the 10 percent level. When ES and ENPP are included, ENPP has a positive coefficient and is significant at the 10 percent level.

\subsection{Conclusion}

This paper extends the foreign aid literature by adopting elements from research of fiscal policy outcomes to explore institutional factors within donor countries for why real levels of tied aid remain above zero despite the focus of the development community to untie aid. The institutional factors considered are the fragmentation of the executive power, measured by the number of spending ministers and the simple and effective number of political parties with representation in government, and the position of government vis-à-vis legislative composition, measured by the excess number of seats held by the governing coalition and the simple and effective number of political parties with representation in government. 
The results indicate, as far as the fragmentation of the executive power is concerned, the impact of the number of spending ministers is stronger and more robust than the simple and effective number of political parties in the governing coalition. The simple number of political parties in the governing coalition is statistically significant in the full sample when all countries were considered, when the model was re-estimated excluding one country every time, and in the long term but is sensitive to different individual time periods considered. As for the position of government vis-à-vis legislative composition, the percentage of excess seats in parliament is significant in the full sample but is somewhat sensitive to the inclusion of countries in the sample. The number of political parties with representation in government is significant but sensitive to different time periods while there is some evidence that the effective number of political parties with representation in government is significant in the long term but is sensitive to different individual time periods considered.

The results provide some evidence that as the number of decision makers within the government coalition increases, the more aid is tied. This result is particularly strong for the number of spending ministers. There is also some evidence that a more comfortable margin in terms of government strength allows the ruling coalition to tie less aid. It seems that reducing tied aid, when compared to political security, is often of second order importance to governing coalitions. Therefore if aid tying is to be eliminated, aid distribution should be removed from the political process as much as is realistically possible. Perhaps the political reform aid reformers should pursue is limiting the number of spending ministers since, as noted by Perotti and Kontopoulos (1999), the number of spending ministers is usually not fixed in the constitution so it is more easily reduced than changing electoral laws (such as reducing the degree of proportionality in order to increase the political strength of governments), which "are frequently 
deep-rooted in the culture of a nation, and in any case it takes a long and politically dangerous constitutional reform to amend them."

Another policy that may be helpful is to set clear and public benchmarks that must be met for aid to be tied rather than leaving it solely to the political process. While this may be a second best policy compared to eliminating tied aid, such benchmarks would place the burden of proof to tie aid on companies/interest groups to justify the practice in public rather than just through private lobbying. Such a process could increase accountability and decrease inefficiencies in the aid process. By making aid distribution less politicized, the incentives for aid donors to satisfy their constituents first decreases and the possibility of aid being disbursed in a more effective manner for the aid recipient increases. 


\section{Chapter 3}

\section{Exerting Political Influence: Does Foreign Aid of Development Assistance Committee Countries Influence Voting Coincidence?}

\subsection{Introduction}

Promoting economic growth and social development within the aid recipient country, such as achieving the Millennium Development Goals (MDGs), are often the stated goals of foreign aid donors (Theile et al. 2007) ${ }^{19}$ even though donor intention plays a large role in the distribution of foreign aid (Maizel and Nissanke 1984, White and Morrissey 1997, and Alesina and Dollar 2000). Donor intention has included distributing aid to further foreign policy objectives (Zimmerman 1993 and Ruttan 1996) such as fighting communism during the Cold War (Schraeder et al. 1998), helping transition economies adopt market ideals after the Cold War (Boschini and Olofsgard 2001), and fighting terrorism since the September $11^{\text {th }}$ attacks (Harrigan et al. 2006). Though perhaps not a publicly stated goal, donor intention has also included “directing" the political relationship between donor and aid recipient countries (Rai 1980).

How effective is foreign aid in "directing" the political relationship between donor and recipient? This paper addresses the question by specifically analyzing whether foreign aid recipients vote more frequently in accordance with aid donors in United Nations (UN) General Assembly roll call votes after having received foreign aid. This paper differs from previous research in two primary ways. First, this paper considers the influence of each of the 22 members of the Development Assistance Committee $(\mathrm{DAC})^{20}$ in “directing” aid recipient voting, instead of just the United States where most of the earlier research focused. Second, the paper considers the post Cold War era only since the nature of foreign aid has changed with the defeat of

\footnotetext{
${ }^{19}$ For a recent example see U.S. President Barack Obama's speech given at the UN Millennium Development Goals Summit on September 22, 2010 (http://www.usaid.gov/press/speeches/2010/sp100922.html).

${ }^{20}$ The Commission of the European Communities is not a single country with voting powers in the UN and South Korea was not a member of the DAC until January 1, 2010 so they are excluded.
} 
communism (Schraeder et al. 1998) and has shifted more towards eliminating world poverty and achieving the MDGs (Moyo 2009), suggesting that aid donors may be focusing more of their aid for humanitarian rather than political purposes.

All DAC countries are used in the analysis for two reasons. First, examples are abundant that bilateral donors pursue their self-interest in aid allocation (McGillivray 2003). According to the official development agency of the United States, USAID, the U.S. gives foreign assistance to "further America's foreign policy interest in expanding democracy and free markets.",21 Australia's official development agency, AusAid, admits in their mission statement they grant aid "in line with Australia's national interest" ${ }^{\text {22 }}$ while Portugal wants "to support the diffusion and use of the Portuguese language." ${ }^{, 23,24}$ Foreign aid is used by France to promote French culture and by Japan to further its economic interests (Schraeder et al. 1998).

DAC countries are also used because they are the primary donors of Official Development Assistance (ODA), are one of the major international forums responsible for achieving the MDGs, and each DAC country is considered to have a major foreign aid program by the Organization for Economic Cooperation and Development (OECD). ${ }^{25}$ From 1991 to 2008, the ODA gross disbursements of DAC countries was over $\$ 1.8$ trillion (constant 2008 USD) or 73.7 percent of total ODA gross disbursements. In comparison, non-DAC countries and multilateral aid agencies contributed only 2.5 and 23.5 percent of total ODA gross disbursements respectively (Figure 3.1).

\footnotetext{
${ }^{21}$ http://www.usaid.gov/about_usaid/

22 http://www.ausaid.gov.au/

${ }^{23}$ http://www.ipan.mne.gov.pt/

${ }^{24}$ Countries with altruistic sounding mission statement may be playing a signaling game whereas countries who admit the importance of their national interest just may be more honest. It is also difficult to ascertain a meaning in vague mission statements. For example, Canada's aid agency's mission is “to manage Canada's support and resources effectively and accountably to achieve meaningful, sustainable results, and engage in policy development in Canada and internationally, enabling Canada's effort to realize its development objectives" (italics added).

${ }^{25}$ The other members of the OECD that are not part of the DAC do not have major foreign aid programs.
} 
Figure 3.1: Proportion of Total Official Development Assistance by Organization 19912008

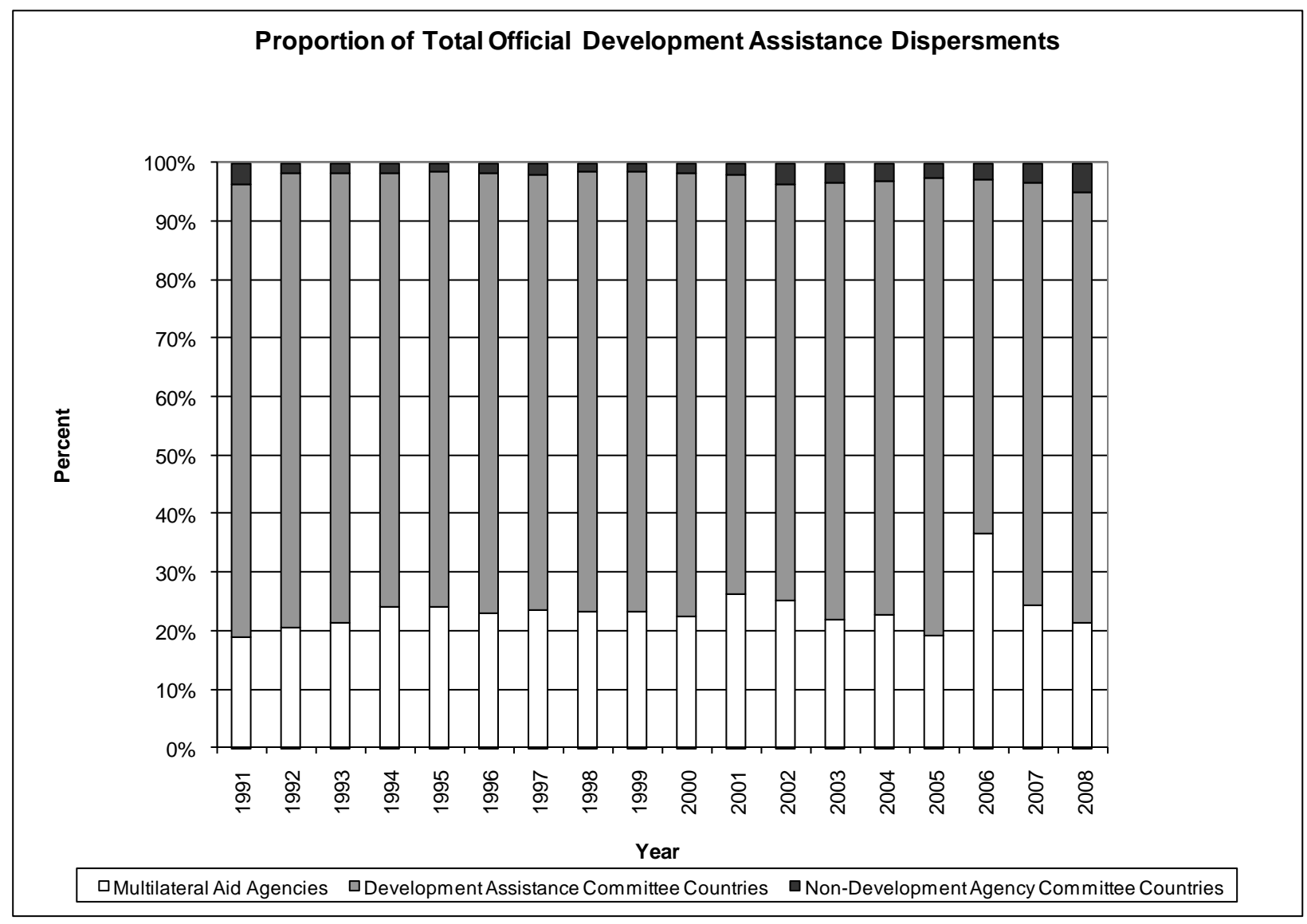

In only one year between the years 1991-2008 was the percentage of total bilateral ODA given by DAC countries lower than 71 percent (60.6 percent in 2006). Figure 3.2 shows total ODA given by each DAC country between 1991 and 2008. Since 1991, 15 of the 22 DAC countries used have contributed at least one percent of total bilateral ODA, five countries have given at least five percent of total ODA given, and two countries (Japan and the United States) have given at least ten percent of total ODA (Figure 3.3). 
Figure 3.2: Total Bilateral Official Development Assistance by Development Assistance Committee Countries 1991-2008

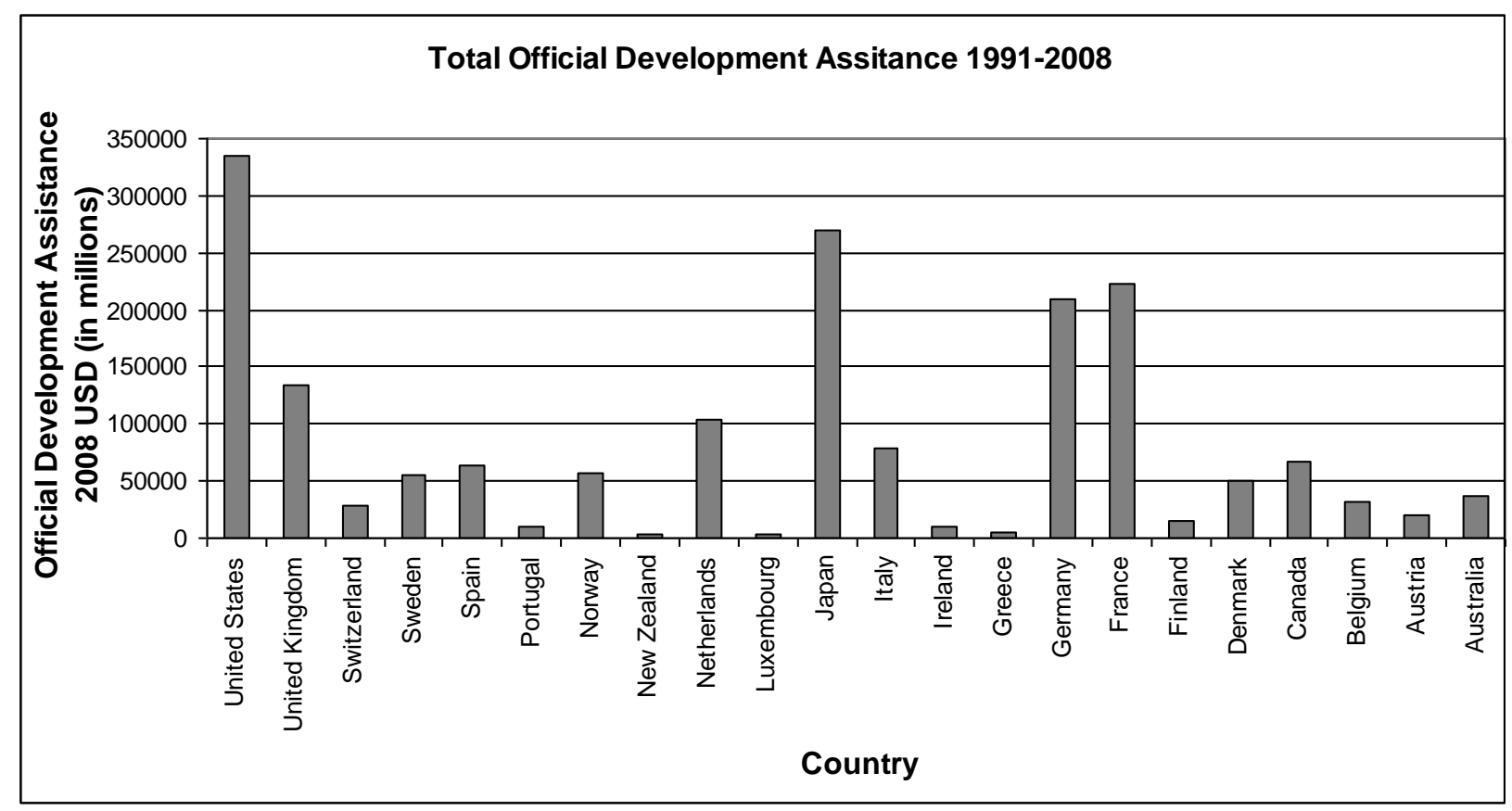

The sheer volume of aid given by individual DAC countries becomes even more striking when compared to the total ODA given by multilateral aid (MLA) organizations like the UN or World Bank (which totaled about $\$ 590$ billion constant 2008 USD between 1991 and 2008). Fourteen countries have given at least as much as five percent of the ODA given by all MLAs while nine countries have given at least ten percent. The United States has given approximately \$335.52 billion, or 57 percent of the total given by MLA’s between 1991-2008.

The paper proceeds as follows. Section two presents a literature review of how foreign aid influences political support. Section three describes the data and introduces the empirical specifications. Section four provides the basic econometric results and provides interpretation. Section five conducts different sensitivity analyses and section six offers concluding remarks. 
Figure 3.3: Proportion of Official Development Assistance Given by the Top 10 Development Assistance Committee Countries 1991-2008

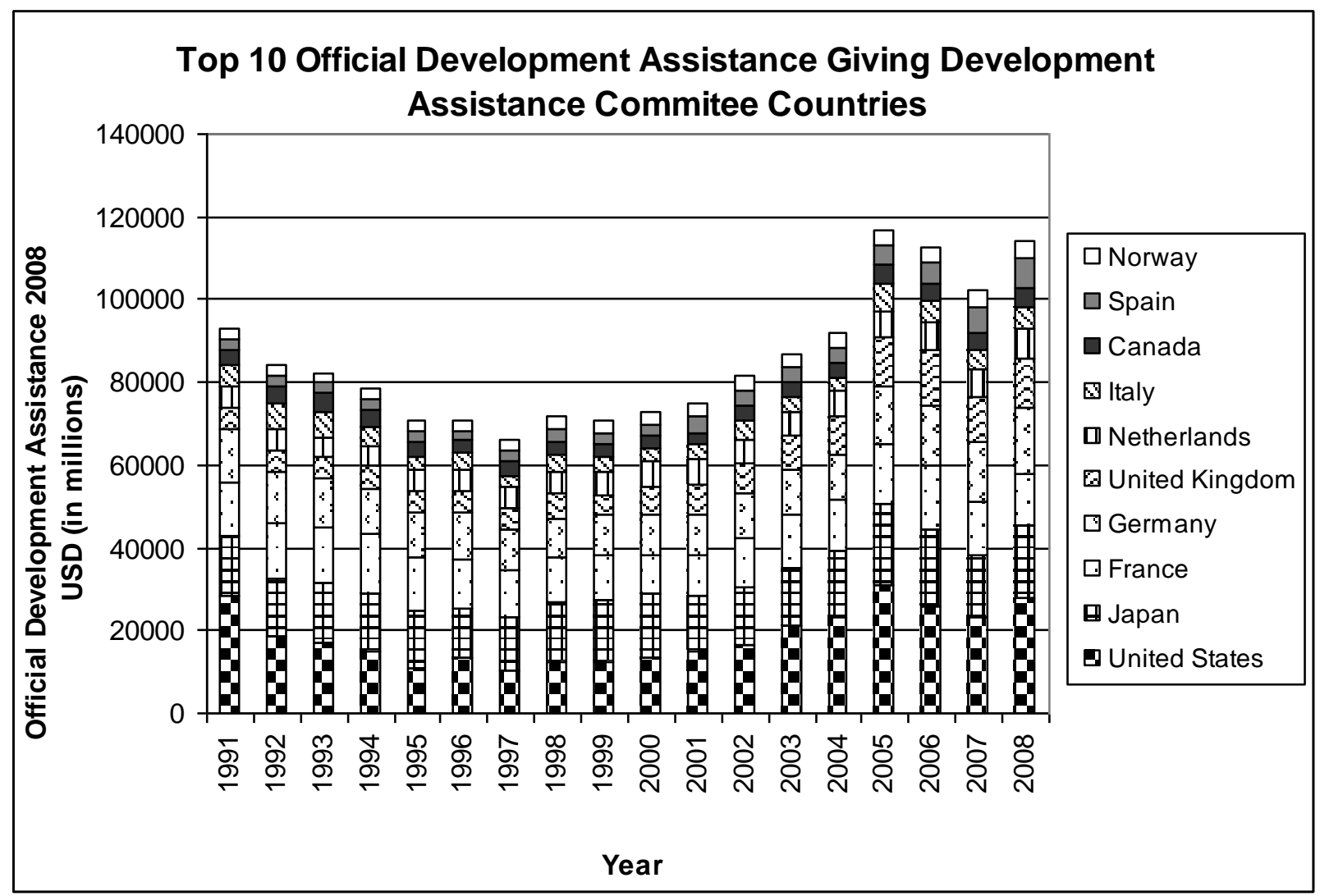

\subsection{Literature Review}

The political nature of foreign aid has long been recognized. ${ }^{26}$ Donor domestic policies (Leogrande and Brenner 1993, Therien and Noel 2000, Fleck and Kilby 2001, and Otter 2003), donor political orientation (Therien 2002 and Fleck and Kilby 2006a), donor political fragmentation (see Chapter 2), and inducing voting support of recipient countries for donor purposes shape foreign aid allocations. Research in donor solicitation of political support through the use of foreign aid has focused on international organizations like the International Monetary Fund (IMF) and World Bank, the UN Security Council, and the UN General Assembly. Oatley and Yackee (2004) and Barro and Lee (2005) find American policymakers influence IMF loan

\footnotetext{
${ }^{26}$ Early recognition of political influence in foreign aid includes Morgenthau (1962) and O’Leary (1967).
} 
practices as the IMF loans more money to governments closely aligned to the United States. Kuziemko and Werker (2006) examine the UN Security Council and find that just for their council membership nonpermanent members receive an average of $\$ 16$ million of additional funding from the United States (the largest financial supporter of the UN) ${ }^{27}$ and $\$ 1$ million of additional funding from the UN on typical years and $\$ 45$ million of additional funding from the U.S. and $\$ 8$ million from the UN during years when the Security council is placed in the spotlight. This additional funding is assumed to be targeted at influencing actual voting behavior. Dreher and Sturm (2006) find that while overall bilateral aid by G7 donors (a direct attempt to influence voting) does not influence UN voting behavior, countries receiving financial support from the IMF and World Bank (an indirect way to influence voting) do vote more frequently with G7 countries in the UN.

The most frequently researched area concerning foreign aid and political support is within the UN General Assembly. Three reasons may explain this research clustering. First, all roll call votes are recorded for each session so voting data is readily available. Second, since the $\mathrm{UN}$ is an important place to court world opinion, close records of voting behavior is kept by G7 countries. For example, the US State Department has kept records of the voting coincidence rates of member countries for "important" votes since 1983. Lastly, the UN is an important player in international affairs. This line of research is summarized by Dreher and Sturm (2006). They find the empirical evidence is inconclusive and mixed. Kato (1969), Kegley and Hook (1991), Sexton and Decker (1992), and Morey and Lai (2006) find aid is not an effective instrument in influencing voting behavior. However, Bernstein and Alpert (1971), Rai (1972 and 1980),

\footnotetext{
${ }^{27}$ As of fiscal year 2009, the U.S. contributes 22 percent of the UN's regular budget and over 27 percent of the UN peacekeeping budget (source: U.S. Secretary of State, "Congressional Budget Justification Volume 1: Department of State Operations Fiscal Year 2011,” pg. 544, 665, at http://www.state.gov/documents/organization/136355.pdf)
} 
Wittkopf (1973), Lundborg (1998), Wang (1999), and Dreher et al. (2008) find foreign aid increases voting coincidence between the donor and recipient countries.

In each of these studies except for Wittkopf (1973) who focuses on the 16 members of the DAC in 1973 and the Soviet Bloc, Lundborg (1998) who analyzes the US and Soviet Union, and Dreher et al. (2008) who investigate the G7 countries, the aid donor considered is the United States. In scope this paper follows most closely to Wittkopf (1973) and Lundborg (1998) in that while it follows Dreher et al. (2008) more closely in its model.

\subsection{Data and Estimation}

\subsubsection{Descriptions of data and variables}

The paper employs pooled time-series cross-section data sets of DAC countries and 155 aid recipient countries (the exact number of aid recipient countries used in each regression depends on the aid donor considered as well as the model specification) from 1991 to 2008. Data is not available for each variable in every year, creating an unbalanced panel and the number of observations in each regression depends on the choice of explanatory variables. A detailed data description, sources, and summary statistics for all variables are provided in Appendices 3A and $3 \mathrm{~B}$ respectively. ${ }^{28}$

The model estimated is a variant of the models used in the literature though it follows most closely to the models used in Wang (1999), Dreher and Sturm (2006), and Dreher et al. (2008). The basic specification is of the following form:

$$
\mathrm{VC}_{\mathrm{i}, \mathrm{t}}=\beta_{0}+\beta_{1} \text { LevelODA }_{\mathrm{i}, \mathrm{t}-1}+\beta_{2} \text { Democracy }_{\mathrm{i}, \mathrm{t}-1}+\beta_{3} \text { National Capability }_{\mathrm{i}, \mathrm{t}-1}+\dot{\varepsilon}
$$

where $i$ and $t$ are the country and year indices, respectively. When the difference GMM estimator of Arellano and Bond (1991) is used, a lagged value of the dependent variable is also included.

\footnotetext{
${ }^{28}$ Specifically, 22 data sets are used, one for each DAC country.
} 
The dependent variable (VC) is a measure of voting coincidence in the UN General Assembly, which is measured differently throughout the literature for two reasons. The first is whether abstentions and absences should be discarded or included. Kegley and Hook (1991) discard abstentions and absences to align their definition of voting coincidence with the US State Department. Following Zimmerman (1993), Palmer et al. (2002), and Hawes (2004) who argue abstentions and absences are important, Barro and Lee (2005) and Dreher et al. (2008) calculate voting coincidence as votes where the donor and recipient country have active agreement in policy positions because donor countries may "bribe recipient governments not only to comply, but also to avoid non-compliance" ${ }^{29}$ (Dreher et al. 2008). Taking the middle ground, Thacker (1999) scales votes in agreement with the donor country as 1 , votes in disagreement as 0 , and treats abstentions or absences as "neutral" by coding them as 0.5 . Wang (1999) considers all votes and then only important votes as a robustness check in his analysis.

The second issue is whether all roll call votes or only certain votes should be counted. Not all issues carry the same significance and not all voting participants have the same attitude regarding the importance of individual votes. Therefore it may be appropriate to consider a subset of roll call votes that are deemed important, such as the US State Department's list. However as noted by Wittkopf (1973), Kegley and McGowan (1981), and Dreher et al. (2008), determining what votes are "important" is subjective and the least subjective measure is to include all votes. This is especially true because of the near impossibility of classifying what votes are similarly important for all 22 of the DAC countries considered. Therefore this study follows Wittkopf (1973), Barro and Lee (2005) and Dreher et al. (2008) and measures voting

\footnotetext{
${ }^{29}$ By not discarding abstentions and absences (active agreement), the denominator for voting coincidence is larger. For example, consider a scenario with 15 total votes and two countries. When abstentions and absences are included, if country A votes identically with country B five times, opposite five times, has three abstentions and two absences the voting coincidence is 33 percent (5/15). When abstentions and absences are not included, the voting coincidence is 50 percent $(5 / 10)$.
} 
coincidence by considering all roll call votes in the UN General Assembly, including near unanimous and unanimous votes. ${ }^{30}$ Voting coincidences are based on voting records from the United Nations Bibliographic Information System (UNBISNET), which records all resolutions along with each member's status and voting actions. Voting actions are recorded as 'Yes', 'No', 'Abstentions', and 'Non-Voting'. Voting coincidence is calculated as the ratio of the total number of times two countries' votes match to the number of resolutions with a roll call vote in the same year.

The key independent variable is the annual amount of a DAC country's bilateral ODA as a proportion of the total bilateral ODA received by the recipient country. This variable assesses the extent to which an aid recipient relies on an individual donor for development assistance (Wang 1999). ${ }^{31}$ Aid disbursements rather than commitments are used because not all commitments are honored by aid donors and are usually disbursed over a period of years (Asiedu and Nandwa 2007) whereas disbursements represents an actual transfer of financial resources rather than promises so it is more likely to affect aid recipient behavior (Dreher et al. 2008).Using disbursements also removes the problem of failed aid promises, such as economically advanced countries giving 0.7 percent of their national income in ODA and the elimination of tied aid. Giving 0.7 percent of national income was first adopted by UN resolution in October of 1970 with the intent of meeting the goal by 1975, but as of 2009 only five countries (Denmark, Luxembourg, the Netherlands, Norway, and Sweden) have achieved this mark while only Belgium, Finland, France, Ireland, Spain, and the United Kingdom pledge to

\footnotetext{
${ }^{30}$ It can be argued that unanimous and near unanimous votes should be excluded because such votes are more likely to be ceremonial rather than in areas where policy disagreement arises. However such exclusions are still purely subjective and sometimes even near unanimous votes have significant meaning for the countries in the extreme minority. For example, an analysis of votes concerning Israel highlights the close relationship between Israel and the United States and it is not unusual for the two countries to be alone or near alone voting together. In the time period 1991-2009, Israel has the highest voting coincidence with the United States averaging 70.5 percent.

${ }^{31}$ ODA is measured by the OECD as grants + loans - repayment of loans. Net disbursements will be negative for years where repayments on loans made by the recipient country exceed ODA disbursements to that country.
} 
meet this goal by 2015 in order to comply with the MDGs. ${ }^{32}$ The promise of eliminating tied aid is also slow as 15 percent of ODA is still tied and only Ireland and the United Kingdom have eliminated this practice even though the aid community has called for the end of the practice over the years (1969 Pearson Committee and the 2005 Paris Declaration on Aid Effectiveness) because it increases the direct costs of aid to the recipient by an average of 15 to 30 percent (Jepma 1991).

A measurement of democracy from Cheibub, Gandhi, and Vreeland (2010) is included because democratic countries tend to vote together (Thacker 1999 and Voeten 2000) and UN voting blocks are relatively stable (Holcombe and Sobel 1996). While many studies use other measures of democracy such as the democracy index provided by Freedom House (Barro and Lee 2005 and Dreher and Sturm 2008) ${ }^{33}$, Gastil's annual measurement of political rights and civil freedoms (Wang 1999), or the Polity IV measure, these measurements are insufficient and should not be used in linear regressions since using indices as a linear regressor requires the measure to be scaled in cardinally constant increments. However these indicator variables are ordinal in nature so cardinal inferences are unclear. The dichotomous variable used in this study does not suffer from this flaw and is therefore a superior measure of democracy when compared to other democracy indices (Cheibub, Gandhi, and Vreeland 2010).

The last variable in the basic model is a measurement of national capability. It is a measure of "hard" power, or power obtained through economic or military power used to influence the behavior of other political powers as opposed to "soft" power which is power produced through persuasion (diplomacy), history, or culture. Wang (1999) argues stronger countries are more independent and show foreign policy defiance possibly resulting in a lower

\footnotetext{
32 The recent global recession may hurt progress towards this goal as the amount of aid dropped from 2008 to 2009 for Austria, Germany, Greece, Ireland, Italy, the Netherlands, Portugal, and Spain.

${ }^{33}$ The Freedom House measure was tested and did not significantly change the results.
} 
voting coincidence. Dreher and Sturm (2006) show national capability is robustly associated with UN voting behavior while Dreher et al. (2008) find greater national capability significantly reduces voting coincidence with the United States but does not have a significant impact on voting coincidence with other G7 countries.

\subsubsection{Methodology}

Fixed country and time effects are included in all regressions (not shown for reasons of space) as specified by the Hausman test to partial out common shocks that may not be adequately captured by the other exogenous variables. ${ }^{34}$ Since the aid measures may be endogenous because aid could adjust to voting patterns (i.e. rewarding aid recipients for "good behavior") and the possibility that voting coincidence and aid are jointly influenced by common determinants (Dreher et al. 2008), different estimation techniques are used.

Regressions are first estimated using Ordinary Least Squares (OLS) for Denmark, the Netherlands, Norway, and Sweden (the Nordic countries) and Two-Stage Least Squares (2SLS) for the non-Nordic countries. The OLS estimates for the non-Nordic countries should not suffer from bias because their aid is not affected by the UN voting behavior of aid recipients (Stokke 1989, Alesina and Dollar 2000, and Gates and Hoeffler 2004). Following Kilby (2006) and Dreher et al. (2008), the 2SLS estimation uses "good donor" instruments for the aid variables of the non-Nordic countries as suggested by Fleck and Kilby (2006a and 2006b). The instruments used are the ODA variables of Denmark, the Netherlands, Norway, and Sweden because their aid should be correlated with the aid patterns of the other DAC countries since major donors focus on the same set of 'aid darlings' (Theile et al. 2007).

\footnotetext{
${ }^{34}$ As noted by Roodman (2006), individual dummies for each year is necessary in GMM estimation as the estimator assumes no correlation across individuals in the idiosyncratic disturbances.
} 
The difference GMM estimator of Arellano and Bond (1991), another method of correcting for possible endogeneity, is employed to check the robustness of the 2SLS results. The GMM results are based on the one-step estimator implemented by Roodman (2006) and use the lagged levels of the regressors as instruments for the first-differenced regressors. The standard errors are robust to heteroskedasticity and arbitrary patterns of autocorrelation within countries. The Hansen $\mathrm{J}$ test is used to determine the validity of the instruments used and the ArellanoBond test of second-order autocorrelation (which detects autocorrelation in levels), which must be absent in order for the estimator to be consistent, is also used. ${ }^{35}$ In this specification, a lagged dependent variable is included to model the dynamics of the model because fixed effects models only estimate short-run effects since it is based on the time series component of the data.

\subsection{Results for the basic model}

Table 3.1 reports the results when estimated with OLS (for the Nordic countries) and 2SLS (for the non-Nordic countries). For the OLS results, only Norway does not show a statistically significant relationship between aid and voting coincidence. A ten percent increase in the share of aid increases voting coincidence by 0.247 percent for Denmark, 0.017 percent for the Netherlands, and 0.087 percent for Sweden. While the literature is in agreement that the Nordic countries do not use their foreign aid for selfish political motivations, the positive coefficients are expected according to the general hypothesis that aid and voting coincidence are positively associated.

\footnotetext{
${ }^{35}$ The null hypothesis of the Arellano-Bond test of second-order autocorrelation is the absence of autocorrelation and is applied to the differenced residuals. A higher p-value is preferred.
} 
For the 2SLS results, the instruments appear valid since the Hansen $\mathrm{J}$ statistic does not reject the overidentifying restrictions at conventional levels of significance. ${ }^{36}$ The results show a ten percent increase in the share of foreign aid increases voting coincidence by 0.051 percent for France, 0.126 percent for Germany, 0.076 percent for the United Kingdom, 0.091 percent for Canada, 0.021 percent for Spain, 0.89 percent for Belgium, and 1.389 percent for New Zealand. Japan has a negative coefficient on aid (-0.022) though this negative result is economically insignificant and may have little meaning because Japan focuses its foreign aid to further its economic rather than political interests (Schraeder et al. 1998). Therefore a measure of voting coincidence in the UN General Assembly may not be an appropriate measure of foreign aid influence for countries interested in influencing factors other than political interests. ${ }^{37}$ However, it should also be noted the empirical results for Japan also match the negative correlation between average ODA given each year and average voting coincidence from 1991-2008 (see Figure 3.4). For either specification, national capability and democracy are not statistically significant

Table 3.2 reports the difference GMM estimates. Unlike Dreher et al. (2008) who use two lags of the dependent variable because the Sargan test rejects the instruments in some cases when only one lag is used, this study includes only one lag because the Hansen $\mathrm{J}$ test does not reject the instruments in almost all cases when only one lag is used. The inclusion of a second lag does not change the basic findings and these results are available upon request. The number of instruments is also included in Table 3.2 and the following tables. For each country except for

\footnotetext{
${ }^{36}$ These results are in-line with Dreher et al. (2008) who finds the instruments are valid using the Sargan test. The null hypothesis of the Hansen $\mathbf{J}$ test and the Sargan test is the same: the instruments as a group are exogenous thus a higher p-value is preferred.

${ }^{37}$ Dreher et al. (2008) find program aid for Japan, comprising 20.8 percent of Japanese total aid, does have a negative effect on voting coincidence. However, they caution the robustness of this finding because the Sargan test rejects the validity of the instruments used in the estimation.
} 
Portugal, the number of instruments used is less than the number of groups (countries), satisfying a standard rule of thumb regarding instrument proliferation. The danger of instrument proliferation is that it will overparameterize the endogenous variables which will fail to expunge their endogenent component and bias coefficient estimates (Roodman 2006).

The results show a positive relationship of voting coincidence and foreign aid share for Canada, France, Spain, and the United Kingdom, with similar magnitudes to the 2SLS results. ${ }^{38}$ The insignificance of the variable of interest for the Nordic countries may suggest their aid is not used for political and that the OLS results may suffer from omitted variable bias because of the exclusion of the lagged voting coincidences. Japan again shows a statistically significant negative relationship giving additional credence for Japan using foreign aid for reasons other than political influence. Italy and Finland also show negative relationships between voting coincidence and foreign aid share. ${ }^{39}$ Italy's negative result follows the same sign as project aid did in the Dreher et al. (2008) study though the same caution of possible invalid instruments should be noted (see footnote 37 ).

Finland's results may be explained by its aid behavior. It is the only Nordic country to not successfully give 0.7 percent of its national income to foreign aid and the most likely of the Nordic countries to focus its aid to recipients in its geographical region (Gates and Hoeffler 2004) so perhaps geographical considerations are more important than political considerations.

\footnotetext{
${ }^{38}$ It may be inappropriate to interpret these results as saying donor countries are purposely using aid to change voting patterns of recipient countries instead of saying that aid is influencing voting patterns even if it is not the donor's intention. An ad hoc way of testing whether it was the donor's intention to "buy" votes with aid is to estimate the basic specification and keep the fitted values, which can be interpreted as the level of support a country expected and wanted given its donation. These fitted values are then subtracted from the actual observations of voting coincidence to create a new variable. This new variable is then regressed against the LevelODA $\mathrm{i}_{\mathrm{i}, t+1}$ and an intercept. If aid donors are successful in purposively "buying" votes, the null hypothesis suggests the sign of the coefficient of the explanatory variable should be positive and statistically significant. When estimated for all 22 countries, the coefficient of the explanatory variable was not found to be statistically significant in any case.

${ }^{39}$ Like Japan the negative relationship between voting coincidence and foreign aid is seen in the raw data graphs when average ODA is plotted with average voting coincidence over the time period analyzed (see Figure 4).
} 
Again the measurement of national capability is statistically insignificant though the measurement of democracy is statistically significant and positive for Switzerland and Austria. The magnitudes are large as aid recipient countries that are democracies increase their voting coincidence with Switzerland and Austria by 5.03 and 11.29 percent respectively.

The results lead to a secondary question as to why the empirical results for countries differ. While a full consideration is outside the scope of this paper, a few observations are proffered. Sometimes the mission statement of a country's development agency is vague and it is difficult to ascertain anything beyond a general goal. A good example is the emission statement of France's development agency which states their purpose is to "finance development." Countries pursue multiple objectives when granting aid (Isenman and Ehrenpreis 2003) so influencing voting coincidence may not be of first-order significance. Examples include Japan, who uses aid to further economic rather than political interests (Schraeder et al. 1998), and Finland (see above). Just like it is unreasonable to assume each country has the same political goals with their voting behavior in the UN, it would be unreasonable to assume each country has the same or even similar objectives with their aid programs, even if the rhetoric converges to a few main themes such as poverty reduction.

The results could also be interpreted as a lower bound of political influence because of the similar voting coincidence rates among DAC countries (see Table 3.9) and the possibility of free riding. The average voting coincidence among DAC countries over the whole time period is significantly higher than the average voting coincidence rates for DAC versus non-DAC countries (see Appendix 3B). This is true even for the United States, the outlier among DAC countries in its voting patterns, as its voting coincidence rates with DAC countries is still significantly higher than its voting coincidence with non-DAC countries. The high voting 
coincidence among DAC countries provides an incentive for countries to achieve their political goals by free riding off countries that share their same political goals but also give foreign aid. The free riding country could therefore further its own political agenda without sharing the cost of the distribution of aid. Such behavior would indicate that foreign aid acts like a public good and may be underprovided since once one country deploys aid other countries can enjoy the benefits of that aid's distribution and do so at a lower cost to themselves.

In addition to using the raw data in considering voting coincidences among DAC countries, factor analysis was employed to analyze the relationships between the voting patterns of the DAC countries. ${ }^{40,41}$ If the voting patterns of the DAC countries are similar, the argument that countries can free ride off the aid of another country becomes stronger. The factor analysis condensed all the similarities in the voting patterns for all the DAC countries and identified two significant factors to help explain the voting groups within the DAC. ${ }^{42}$ Factor one explained 81.1 percent of the total variation in voting patterns among all the DAC countries with the entire DAC countries loaded positively on factor one. On average all the DAC countries, except for the United States, had a 91.2 percent correlation with factor one (the US has a 42.9 percent correlation with factor one). An interpretation of this result is that all $22 \mathrm{DAC}$ countries, even the United States despite its relatively low voting coincidence with the rest of the DAC countries,

\footnotetext{
${ }^{40}$ Various rules of thumb have been proposed regarding the ratio of observations to variables. These rules of thumb typically range between 5 to 10 observations per variable. In this analysis, there were 1284 observations (votes) and 22 variables (countries).

${ }^{41}$ Factor analysis depends on an ordinal scale of value for the data being analyzed and does not accept missing values. Therefore, two changes were made to the voting data. The first was how the votes were scaled. 'Yes' votes were given a value of 1 , 'No' votes were given a value of -1 , and 'Abstentions' and 'Non-Voting' were given values of 0 (see Rummel 1970). The second change regarded Switzerland. Switzerland did not join the UN until 2002 but because the missing data points need to be assigned a value (i.e. the votes that were cast before Switzerland joined the UN need to be classified), all the roll call votes prior to 2002 for Switzerland were assigned the neutral value of 0 . Given Switzerland's historic stance of neutrality on world issues, this assumption seems justified.

${ }^{42}$ Factor analysis produces the same number of factors as variables ( 22 in this case). However, only the first two factors were kept because their eigenvalues were greater than one, a standard cutoff point in factor analysis called the Kaiser criterion (Kaiser 1960).
} 
vote together on most UN roll call votes (giving credence to the hypothesis that democracies and countries with relatively similar wealth levels vote together).

The second factor explained 4.7 percent of the total variance (the factors are completely unrelated from one another in factor analysis) in DAC countries and this factor set the United States apart from the other DAC countries because the voting behavior of the United States accounted for a large proportion of the variance within this second factor (i.e. the United States was the only DAC country that was highly correlated with this second factor). The United States had a correlation of 78.5 percent with factor two, meaning that it was highly loaded with factor two while the average correlation for the other 21 DAC countries was -2.4 percent, showing that none of the other countries were loaded highly with factor two (Australia, Canada, France, and the United Kingdom were positively correlated with factor two but not strongly correlated). Factor two describes the votes where the United States voted contrary to the other DAC countries and the correlations provide evidence the US is the only DAC country that on a semiconsistent basis votes differently from the DAC voting bloc. The United States votes most differently from the other DAC countries in issues involving Israel. When Israel is included in the factor analysis, the correlation between the United States and factor two (this provides further evidence that factor two describes the votes where Israel and the United States are in conflict with the other DAC countries) increases to 80.4 percent and Israel's correlation with factor two is 79.5 percent. It appears from the results of the factor analysis that if free riding is a significant problem and the regression results represent a lower bound of political influence, countries are unlikely to be free riding off the United States aid and are more likely to be free riding off of the 
aid of other countries. An effort to identify whether free riding exists in foreign aid may be an attractive avenue of future research. ${ }^{43}$

\footnotetext{
${ }^{43}$ In a related area of research, Mascarenhas and Sandler (2006) find evidence that donors view the contributions of other countries as complementary to their own contributions but uncover no evidence of cooperative behavior among countries.
} 
Table 3.1: Bilateral ODA and UN Voting for ODA Giving Countries (OLS and 2SLS)

\begin{tabular}{|c|c|c|c|c|c|c|c|c|c|c|c|}
\hline Variable & United States & Japan & France & Germany & United Kingdom & Netherlands & Italy & Canada & Spain & Norway & Sweden \\
\hline \multirow[t]{2}{*}{ Level ODA $(t-1)$} & 0.0001 & -0.0022 & 0.0051 & 0.0126 & 0.0076 & 0.0017 & -0.0849 & 0.0091 & 0.0021 & 0.0134 & 0.0087 \\
\hline & $(0.0001)$ & $(0.0004) * * *$ & $(0.0009)^{* * *}$ & $(0.0077)^{*}$ & $(0.0013)^{* * *}$ & $(0.0003) * * *$ & $(0.0533)$ & $(0.0019)^{* * *}$ & $(0.0003)^{* * *}$ & $(0.0259)$ & $(0.0038) * * *$ \\
\hline \multirow[t]{2}{*}{ Democracy $(t-1)$} & 0.0178 & 0.7829 & 0.5726 & 0.3068 & 0.7283 & 0.7305 & -0.8064 & 0.0976 & 0.4996 & -0.2176 & 0.461 \\
\hline & $(0.7900)$ & $(1.9228)$ & $(1.5324)$ & $(1.7836)$ & $(1.6132)$ & $(1.6035)$ & $(1.7434)$ & $(1.8263)$ & $(1.9581)$ & $(1.9885)$ & $(2.1123)$ \\
\hline \multirow[t]{2}{*}{ National Capabilities $(t-1)$} & 1.4515 & 0.3592 & -0.1703 & 0.0266 & 0.1351 & 33.7229 & 0.0659 & 0.0928 & -0.0876 & -14.2821 & -12.1623 \\
\hline & $(1.0310)$ & $(0.2455)$ & $(0.2094)$ & $(0.2527)$ & $(0.2226)$ & $(26.5790)$ & $(0.2483)$ & $(0.2503)$ & $(0.2549)$ & $(33.2281)$ & $(31.4841)$ \\
\hline R-squared (within) & 0.63 & 0.15 & 0.13 & 0.18 & 0.27 & 0.14 & 0.22 & 0.13 & 0.09 & 0.13 & 0.10 \\
\hline Number of countries & 102 & 101 & 102 & 102 & 101 & 145 & 100 & 102 & 95 & 139 & 136 \\
\hline Number of observations & 1206 & 1239 & 1254 & 1256 & 1224 & 1992 & 1161 & 1248 & 1051 & 1774 & 1776 \\
\hline Hansen J stat. (p-value) & 0.50 & 0.45 & 0.50 & 0.97 & 0.94 & & 0.38 & 0.99 & 0.40 & & \\
\hline Method & 2SLS & 2SLS & 2SLS & 2SLS & 2SLS & OLS & 2SLS & 2SLS & 2SLS & OLS & OLS \\
\hline
\end{tabular}

Robust standard errors are in parentheses. $* * *=1 \%, * *=5 \%, *=10 \%$ significance level.

\begin{tabular}{|c|c|c|c|c|c|c|c|c|c|c|c|}
\hline Variable & Denmark & Australia & Belgium & Switzerland & Austria & Finland & Portugal & Ireland & Greece & Luxembourg & New Zealand \\
\hline Level ODA $(t-1)$ & $\begin{array}{c}0.0247 \\
(0.0052)^{* * *}\end{array}$ & $\begin{array}{l}0.0424 \\
(0.7741)\end{array}$ & $\begin{array}{c}0.0890 \\
(0.0216) * * *\end{array}$ & $\begin{array}{l}-0.0056 \\
(0.8557)\end{array}$ & $\begin{array}{c}0.0241 \\
(0.1644)\end{array}$ & $\begin{array}{l}-1.5065 \\
(1.2636)\end{array}$ & $\begin{array}{l}-0.9263 \\
(1.8635)\end{array}$ & $\begin{array}{l}-1.9144 \\
(4.2058)\end{array}$ & $\begin{array}{c}0.0337 \\
(5.7893)\end{array}$ & $\begin{array}{l}-2.6871 \\
(3.0428)\end{array}$ & $\begin{array}{c}1.3894 \\
(0.2238)^{* * *}\end{array}$ \\
\hline Democracy $(t-1)$ & $\begin{array}{c}0.5438 \\
(1.9048)\end{array}$ & $\begin{array}{c}0.1175 \\
(1.8788)\end{array}$ & $\begin{array}{l}-0.1829 \\
(1.8565)\end{array}$ & $\begin{array}{r}2.1702 \\
(3.4449)\end{array}$ & $\begin{array}{l}-1.7613 \\
(3.5030)\end{array}$ & $\begin{array}{c}2.3419 \\
(1.6378)\end{array}$ & $\begin{array}{l}-0.0163 \\
(5.0694)\end{array}$ & $\begin{array}{c}1.8459 \\
(2.0091)\end{array}$ & $\begin{array}{c}0.2943 \\
(1.6692)\end{array}$ & $\begin{array}{l}-0.8804 \\
(1.671)\end{array}$ & $\begin{array}{c}1.6839 \\
(1.5937)\end{array}$ \\
\hline National Capabilities $(t-1)$ & $\begin{array}{c}22.0323 \\
(25.7772)\end{array}$ & $\begin{array}{l}-0.1837 \\
(0.2930)\end{array}$ & $\begin{array}{c}0.2799 \\
(0.2244)\end{array}$ & $\begin{array}{l}-0.3684 \\
(0.5303)\end{array}$ & $\begin{array}{l}-0.0979 \\
(0.2175)\end{array}$ & $\begin{array}{c}0.0628 \\
(0.2528)\end{array}$ & $\begin{array}{c}0.2239 \\
(0.5088)\end{array}$ & $\begin{array}{l}-0.0875 \\
(0.6797)\end{array}$ & $\begin{array}{c}0.3109 \\
(0.7238)\end{array}$ & $\begin{array}{c}0.0095 \\
(0.5799)\end{array}$ & $\begin{array}{l}-0.3124 \\
(0.3344)\end{array}$ \\
\hline R-squared (within) & 0.10 & 0.40 & 0.14 & 0.14 & 0.11 & 0.17 & 0.07 & 0.14 & 0.10 & 0.08 & 0.16 \\
\hline Number of countries & 121 & 80 & 100 & 91 & 123 & 96 & 61 & 92 & 76 & 88 & 75 \\
\hline Number of observations & 1429 & 796 & 1153 & 532 & 822 & 1101 & 356 & 1008 & 505 & 867 & 815 \\
\hline Hansen J stat. (p-value) & & 0.16 & 0.44 & 0.15 & 0.18 & 0.19 & 0.37 & 0.24 & 0.24 & 0.42 & 0.64 \\
\hline Method & OLS & 2SLS & 2SLS & 2SLS & 2SLS & 2SLS & 2SLS & 2SLS & 2SLS & 2SLS & 2SLS \\
\hline
\end{tabular}

Robust standard errors are in parentheses. $* * *=1 \%, * *=5 \%, *=10 \%$ significance level. 


\section{Figure 3.4: Official Development Assistance and Voting Coincidence for Select Countries 1991-2008}
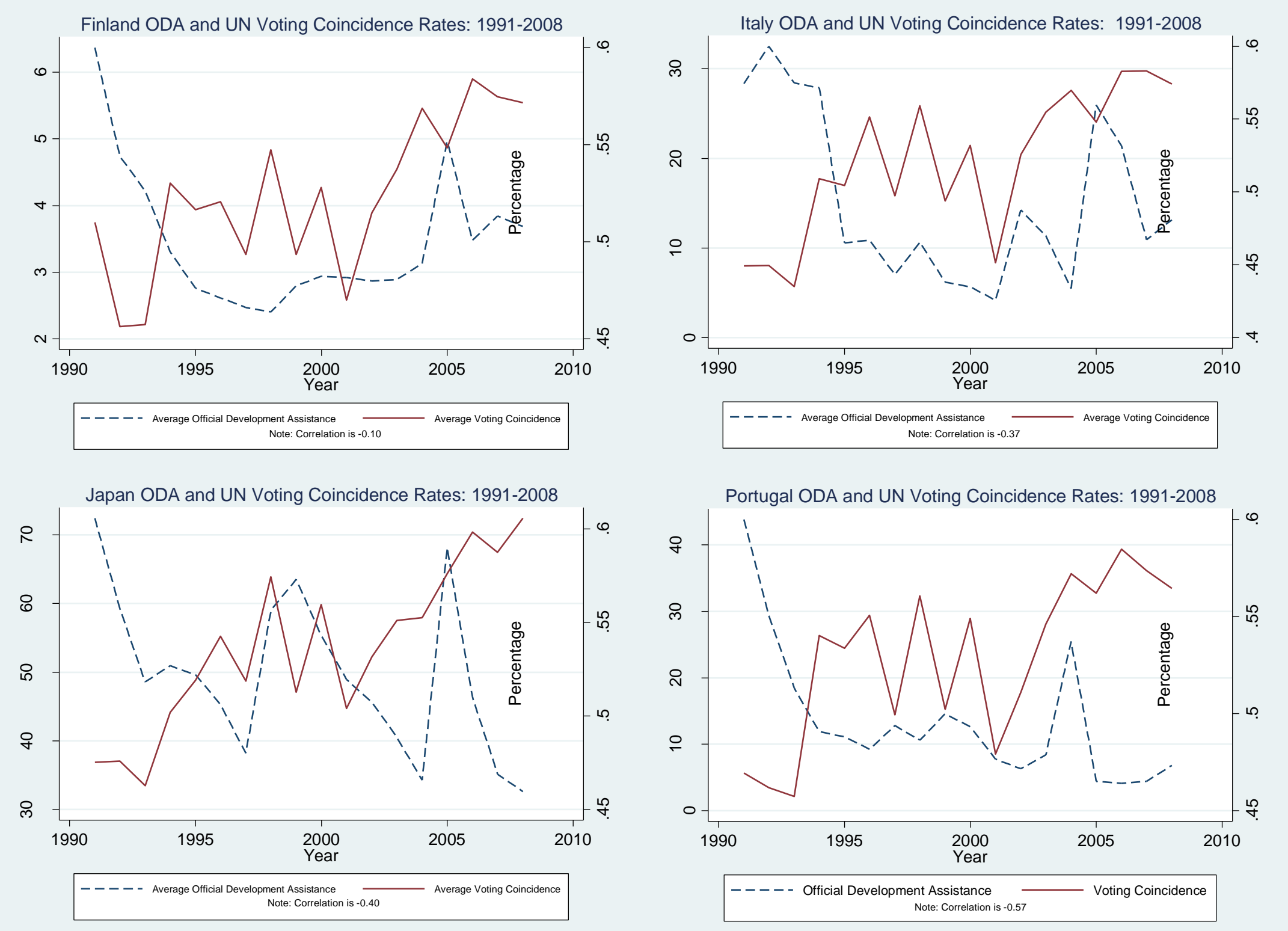
Table 3.2: Bilateral Aid and UN Voting for ODA Giving Countries (GMM)

\begin{tabular}{|c|c|c|c|c|c|c|c|c|c|c|c|}
\hline Variable & United States & Japan & France & Germany & United Kingdom & Netherlands & Italy & Canada & Spain & Norway & Sweden \\
\hline \multirow[t]{2}{*}{ Voting coincidence $(t-1)$} & 0.1522 & 0.0871 & 0.1527 & 0.1846 & 0.1437 & 0.2187 & 0.2660 & 0.2091 & 0.1451 & 0.2117 & 0.1946 \\
\hline & $(0.1291)$ & $(0.1081)$ & $(0.1074)$ & $(0.1119)^{*}$ & $(0.1107)$ & $(0.0737)^{* * *}$ & $(0.1116)^{* *}$ & $(0.1052)^{* *}$ & $(0.1057)$ & $(0.0885)^{* *}$ & $(0.0909)^{* *}$ \\
\hline \multirow[t]{2}{*}{ Level ODA $(t-1)$} & 0.0001 & -0.0011 & 0.0024 & 0.0006 & 0.0037 & 0.0411 & -0.0930 & 0.0069 & 0.0017 & -1.6652 & 0.2574 \\
\hline & $(0.0001)$ & $(0.0004)^{* * *}$ & $(0.0008)^{* * *}$ & $(0.0146)$ & $(0.0014)^{* * *}$ & $(0.0529)$ & $(0.0343) * * *$ & $(0.0021)^{* * *}$ & $(0.0005)^{* * *}$ & (1.1997) & $(0.4434)$ \\
\hline \multirow[t]{2}{*}{ Democracy $(t-1)$} & 1.2969 & 0.5989 & 1.2876 & 1.8322 & 1.9309 & 3.5134 & 1.9254 & 0.0231 & 1.5409 & 2.4761 & 3.9890 \\
\hline & (1.0102) & (2.2146) & $(2.0791)$ & $(2.2840)$ & (2.2344) & $(2.5630)$ & $(2.6632)$ & $(0.0218)$ & (2.4864) & $(2.8484)$ & $(2.9096)$ \\
\hline \multirow[t]{2}{*}{ National Capabilities $(t-1)$} & 0.7211 & 0.5244 & 0.0462 & 0.5734 & -0.1297 & -0.2511 & -0.2314 & 0.8712 & -0.8183 & 1.1745 & -0.6298 \\
\hline & $(0.8888)$ & (1.1886) & (1.1357) & (1.0335) & $(0.9686)$ & (1.3068) & $(0.9401)$ & (1.1477) & $(0.7679)$ & $(2.2626$ & $(1.3881)$ \\
\hline Number of countries & 98 & 97 & 98 & 98 & 97 & 139 & 97 & 98 & 92 & 125 & 124 \\
\hline Number of observations & 1010 & 1041 & 1057 & 1061 & 1025 & 1790 & 944 & 1054 & 855 & 1580 & 1580 \\
\hline Arellano-Bond test ( $\mathrm{p}$-value) & 0.11 & 0.38 & 0.57 & 0.23 & 0.54 & 0.17 & 0.41 & 0.29 & 0.48 & 0.22 & 0.14 \\
\hline Number of instruments & 53 & 53 & 53 & 53 & 53 & 34 & 53 & 53 & 53 & 34 & 34 \\
\hline Hansen J stat. (p-value) & 0.29 & 0.56 & 0.14 & 0.11 & 0.14 & 0.02 & 0.12 & 0.13 & 0.26 & 0.10 & 0.03 \\
\hline
\end{tabular}

Robust standard errors in parentheses. $* * *=1 \%, * *=5 \%, *=10 \%$ significance level.

\begin{tabular}{|c|c|c|c|c|c|c|c|c|c|c|c|}
\hline Variable & Denmark & Australia & Belgium & Switzerland & Austria & Finland & Portugal & Ireland & Greece & Luxembourg & New Zealand \\
\hline Voting coincidence $(t-1)$ & $\begin{array}{c}0.2956 \\
(0.0868)^{* * *}\end{array}$ & $\begin{array}{c}0.1137 \\
(0.1196)\end{array}$ & $\begin{array}{c}0.0915 \\
(0.1101)\end{array}$ & $\begin{array}{c}0.1265 \\
(0.1302)\end{array}$ & $\begin{array}{l}-0.0771 \\
(0.1507)\end{array}$ & $\begin{array}{c}0.2273 \\
(0.1222)^{*}\end{array}$ & $\begin{array}{c}0.1543 \\
(0.1397)\end{array}$ & $\begin{array}{c}0.1579 \\
(0.1249)\end{array}$ & $\begin{array}{c}0.0804 \\
(0.0707)\end{array}$ & $\begin{array}{c}0.1457 \\
(0.0867)^{*}\end{array}$ & $\begin{array}{c}0.0615 \\
(0.1169)\end{array}$ \\
\hline Level ODA $(t-1)$ & $\begin{array}{c}0.4241 \\
(0.6543)\end{array}$ & $\begin{array}{l}-0.0330 \\
(2.7518)\end{array}$ & $\begin{array}{c}0.0326 \\
(0.0232)\end{array}$ & $\begin{array}{c}0.0535 \\
(0.7240)\end{array}$ & $\begin{array}{l}-0.0826 \\
(0.2239)\end{array}$ & $\begin{array}{c}-2.7679 \\
(0.8163) * * *\end{array}$ & $\begin{array}{l}-0.7211 \\
(0.4966)\end{array}$ & $\begin{array}{l}-1.6281 \\
(1.7734)\end{array}$ & $\begin{array}{l}-0.2867 \\
(0.3400)\end{array}$ & $\begin{array}{l}-0.9907 \\
(0.9020)\end{array}$ & $\begin{array}{l}-0.9639 \\
(3.3671)\end{array}$ \\
\hline Democracy $(t-1)$ & $\begin{array}{c}2.7669 \\
(2.7804)\end{array}$ & $\begin{array}{c}-1.1876 \\
2.7518\end{array}$ & $\begin{array}{l}-0.5124 \\
(3.5414)\end{array}$ & $\begin{array}{c}5.0319 \\
(2.3755)^{* *}\end{array}$ & $\begin{array}{c}11.2934 \\
(4.4379)^{* * *}\end{array}$ & $\begin{array}{c}0.7342 \\
(3.0578)\end{array}$ & $\begin{array}{c}0.6909 \\
(3.1986)\end{array}$ & $\begin{array}{c}0.9546 \\
(2.6288)\end{array}$ & $\begin{array}{c}0.7053 \\
(1.9611)\end{array}$ & $\begin{array}{c}3.3701 \\
(3.4052)\end{array}$ & $\begin{array}{c}2.2978 \\
(3.6003)\end{array}$ \\
\hline National Capabilities $(t-1)$ & $\begin{array}{l}-0.5805 \\
(1.1134)\end{array}$ & $\begin{array}{c}2.4593 \\
(2.4323)\end{array}$ & $\begin{array}{c}0.6459 \\
(1.2381)\end{array}$ & $\begin{array}{c}0.0101 \\
(0.8163)\end{array}$ & $\begin{array}{l}-0.1510 \\
(0.2147)\end{array}$ & $\begin{array}{c}0.1781 \\
(1.2978)\end{array}$ & $\begin{array}{c}1.1981 \\
(3.2817\end{array}$ & $\begin{array}{c}0.3443 \\
(1.0216)\end{array}$ & $\begin{array}{l}-1.2606 \\
(1.5186)\end{array}$ & $\begin{array}{c}0.9460 \\
(1.5167)\end{array}$ & $\begin{array}{l}-0.4846 \\
(1.2981)\end{array}$ \\
\hline Number of countries & 113 & 68 & 96 & 83 & 107 & 89 & 51 & 88 & 65 & 85 & 69 \\
\hline Number of observations & 1233 & 629 & 945 & 348 & 338 & 913 & 219 & 832 & 366 & 655 & 665 \\
\hline Arellano-Bond test (p-value) & 0.06 & 0.65 & 0.64 & 0.65 & 0.24 & 0.716 & 0.69 & 0.01 & 0.28 & 0.36 & 0.91 \\
\hline Number of instruments & 34 & 53 & 53 & 21 & 53 & 53 & 53 & 53 & 38 & 53 & 53 \\
\hline Hansen J stat. (p-value) & 0.12 & 0.47 & 0.15 & 0.52 & 0.527 & 0.26 & 0.86 & 0.07 & 0.17 & 0.28 & 0.16 \\
\hline
\end{tabular}

Robust standard errors in parentheses. $* * *=1 \%, * *=5 \%, *=10 \%$ significance level. 


\subsection{Sensitivity Analyses}

This section contains various sensitivity tests. Tables 3.3 through 3.8 test the robustness of the results of the GMM estimation to the inclusion of additional variables suggested in the literature as possible determinants of voting coincidence. These include measures of economic power (GDP per capita, real GDP growth), dependence on foreign support (external debt), "hard" power (the percentage of the labor force who are armed service personnel), and international trade patterns (imports and exports). ${ }^{44}$

Measures of economic power are and "hard" power are included because economically stronger countries may show more foreign policy defiance (Wang 1999), which may result in lower voting coincidence, or may result in higher voting coincidence because countries with similar wealth levels may be converging towards similar preferences. Politically and economically stronger countries with easy access to capital may be less likely to accept bribes and may be less likely to vote with the DAC countries compared to countries who are more constrained in their access to private capital and may need to rely more on public support such as foreign aid (Dreher and Sturm 2006 and Dreher et al. 2008). However, dependence may be higher in times of political instability or crises, making it more difficult to access private capital because less economically secure countries may need assistance from economically stronger countries (Dreher and Sturm 2006). Thus while measures of economic power and dependence on foreign support may be important, their impact on voting patterns is a priori ambiguous.

International trade patterns may also be important to voting coincidence since trade is a potential measure of foreign influence (Stone 2004) and creates interdependence among

\footnotetext{
${ }^{44}$ Measures of distance and colonial relationships may also influence voting coincidence. However, for the sample period analyzed, there is no within-subject variation, though fixed effects methods in non-experimental research controls for all stable characteristics of the countries.
} 
countries which may create similar preferences among trading partners and greater cooperation (Oneal and Russett 1999). This increased dependency may increase a country's responsiveness to external pressure which may lead to voting compliance with the trading partner, particularly if the trading partner is large (Keohane 1967), or if the increased trade dependence also increases recipient fears of losing access to markets of the donor. However, strong economic ties with developed countries may create feelings of exploitation and could give rise to voting against these countries (Kim and Russett 1996). Again, while trade is important, its impact on voting patterns is thus a priori ambiguous.

Table 3.3 includes GDP per capita as a measure of economic wealth. The basic results hold as a ten percent increase in the share of foreign aid increases voting coincidence by 0.021 percent for France, 0.031 percent for the United Kingdom, 0.058 percent for Canada, 0.015 percent for Spain, all similar magnitudes without the inclusion of GDP per capita. Japan, Italy, and Finland each maintain their negative coefficients and magnitudes and the variable of interest for the Nordic countries is again statistically insignificant. For the first time the measure of national capability is statistically significant and has the correct sign, though only at the 10 percent level and only for Spain. The measurement for democracy is again positive, statistically significant, and around the same magnitudes for Switzerland and Austria.

Table 3.4 includes real GDP growth as a measure of economic strength and independence. Once again the basic results for the foreign aid variable hold. France, the United Kingdom, Canada, and Spain have positive coefficients, Japan, Italy, and Finland stubbornly hold to their negative coefficients (the instruments for Italy are valid at the 5 percent level but not the 10 percent level), and the Nordic countries have insignificant coefficients. National 
capability is again statistically insignificant while the measurement for democracy is positive, statistically significant, and around the same magnitudes as earlier for Switzerland and Austria.

Table 3.5 contains external debt as a measure of dependence on foreign power and is more important statistically and in magnitude than the other economic power variables. ${ }^{45}$ The coefficient on external debt is statistically significant and positive for 10 of the 22 countries, giving support to the hypothesis a country with a larger debt load may have a greater reliance on foreign aid and would therefore be expected to increase voting coincidence with the donor country. The coefficient on democracy is again positive and statistically significant for Switzerland and Austria. The basic results for the foreign aid variable are similar to earlier specifications. Portugal's results are suspect because the number of instruments is greater than the number of groups (as evidenced by extremely high Hansen J statistic), though this matches the raw data (Figure 3.4).

Table 3.6 uses a secondary measure of "hard" power since national capability is consistently statistically insignificant. Therefore, the percentage of the labor force who are armed service personnel (AFPTL) is included as a measurement of hard power. Like the argument for national capability, the more formidable a country's military is the more likely it can be politically independent. The coefficient is the expected negative sign but only statistically significant for Austria and Greece. A one percent increase in AFPTL decreases voting coincidence by 1.97 and 1.15 percent respectively. The measurement for democracy is only statistically significant for Switzerland while the coefficients for foreign aid again are analogous with previous specifications.

\footnotetext{
${ }^{45}$ The analysis was also estimated with external debt and GDP per capita included in the same regression. The basic results did not change so they were excluded for reasons of space though are available per request.
} 
International trade patterns may also be a possible determinant of voting coincidence. Table 3.7 includes imports and Table 3.8 includes exports. While the export measure is statistically significant in seven of the DAC countries, the imports measure is statistically significant in only two countries and the coefficients for foreign aid are similar with previous specifications. 
Table 3.3: Bilateral Aid and UN Voting for ODA Giving Countries Including GDP Per Capita (GMM)

\begin{tabular}{|c|c|c|c|c|c|c|c|c|c|c|c|}
\hline Variable & United States & Japan & France & Germany & United Kingdom & Netherlands & Italy & Canada & Spain & Norway & Sweden \\
\hline Voting coincidence $(t-1)$ & $\begin{array}{c}0.1137 \\
(0.1299)\end{array}$ & $\begin{array}{c}0.0701 \\
(0.1089)\end{array}$ & $\begin{array}{c}0.1145 \\
(0.1062)\end{array}$ & $\begin{array}{c}0.1382 \\
(0.1119)\end{array}$ & $\begin{array}{c}0.1111 \\
(0.1088)\end{array}$ & $\begin{array}{c}0.2081 \\
(0.0729)^{* * *}\end{array}$ & $\begin{array}{c}0.2157 \\
(0.1111)^{* *}\end{array}$ & $\begin{array}{c}0.1736 \\
(0.1061)^{*}\end{array}$ & $\begin{array}{c}0.1475 \\
(0.1115)\end{array}$ & $\begin{array}{c}0.1891 \\
(0.0917)^{* *}\end{array}$ & $\begin{array}{c}01592 \\
(0.0928)^{*}\end{array}$ \\
\hline Level ODA $(t-1)$ & $\begin{array}{c}0.0001 \\
(0.0001)\end{array}$ & $\begin{array}{c}-0.0009 \\
(0.0005)^{* *}\end{array}$ & $\begin{array}{c}0.0021 \\
(0.0009)^{* * *}\end{array}$ & $\begin{array}{l}-0.0016 \\
(0.0157)\end{array}$ & $\begin{array}{c}0.0031 \\
(0.0015)^{* *}\end{array}$ & $\begin{array}{c}0.0420 \\
(0.0517)\end{array}$ & $\begin{array}{c}-0.0937 \\
(0.0380)^{* *}\end{array}$ & $\begin{array}{c}0.0058 \\
(0.0022)^{* * *}\end{array}$ & $\begin{array}{c}0.0015 \\
(0.0005)^{* * *}\end{array}$ & $\begin{array}{l}-0.7016 \\
(1.0401)\end{array}$ & $\begin{array}{c}01748 \\
(0.3226)\end{array}$ \\
\hline Democracy $(t-1)$ & $\begin{array}{c}1.3072 \\
(1.0041)\end{array}$ & $\begin{array}{c}0.5139 \\
(2.2019)\end{array}$ & $\begin{array}{c}1.2005 \\
(2.0075)\end{array}$ & $\begin{array}{c}1.6262 \\
(2.1852)\end{array}$ & $\begin{array}{c}1.9634 \\
(2.1864)\end{array}$ & $\begin{array}{c}3.3467 \\
(2.5394)\end{array}$ & $\begin{array}{c}1.6909 \\
(2.5266)\end{array}$ & $\begin{array}{c}2.0519 \\
(2.0993)\end{array}$ & $\begin{array}{c}1.5837 \\
(2.5134)\end{array}$ & $\begin{array}{c}2.8616 \\
(2.7367)\end{array}$ & $\begin{array}{c}3.8062 \\
(2.8286)\end{array}$ \\
\hline National Capabilities $(t-1)$ & $\begin{array}{c}1.1066 \\
(1.1073)\end{array}$ & $\begin{array}{l}-0.3084 \\
0.8644)\end{array}$ & $\begin{array}{l}-0.6934 \\
(0.7913)\end{array}$ & $\begin{array}{l}-0.2617 \\
(0.9145)\end{array}$ & $\begin{array}{l}-0.7301 \\
(0.8047)\end{array}$ & $\begin{array}{l}-0.4009 \\
(1.0436)\end{array}$ & $\begin{array}{l}-1.0491 \\
(0.8925)\end{array}$ & $\begin{array}{c}0.1136 \\
(0.8298)\end{array}$ & $\begin{array}{c}-1.3602 \\
(0.7472)^{*}\end{array}$ & $\begin{array}{c}0.2623 \\
(1.4088)\end{array}$ & $\begin{array}{l}-0.7326 \\
(1.0179)\end{array}$ \\
\hline $\operatorname{GDPC}(t-1)$ & $\begin{array}{l}-0.0001 \\
(0.0010)\end{array}$ & $\begin{array}{c}0.0040 \\
(0.0025)\end{array}$ & $\begin{array}{c}0.0027 \\
(0.0019)\end{array}$ & $\begin{array}{c}0.0023 \\
(0.0025)\end{array}$ & $\begin{array}{c}0.0033 \\
(0.0025)\end{array}$ & $\begin{array}{l}-0.0007 \\
(0.0018)\end{array}$ & $\begin{array}{c}0.0039 \\
(0.0028)\end{array}$ & $\begin{array}{c}0.0029 \\
(0.0020)\end{array}$ & $\begin{array}{c}0.0033 \\
(0.0025)\end{array}$ & $\begin{array}{c}0.0001 \\
(0.0055)\end{array}$ & $\begin{array}{l}-0.0011 \\
(0.0031)\end{array}$ \\
\hline Number of countries & 96 & 93 & 93 & 93 & 93 & 131 & 92 & 93 & 88 & 119 & 116 \\
\hline Number of observations & 966 & 1005 & 1006 & 1010 & 976 & 1690 & 901 & 1003 & 837 & 1488 & 1483 \\
\hline Arellano-Bond test ( $\mathrm{p}$-value) & 0.16 & 0.46 & 0.83 & 0.39 & 0.77 & 0.15 & 0.55 & 0.34 & 0.51 & 0.20 & 0.30 \\
\hline Number of instruments & 54 & 54 & 54 & 54 & 54 & 35 & 54 & 54 & 54 & 35 & 35 \\
\hline Hansen J stat. (p-value) & 0.32 & 0.57 & 0.13 & 0.19 & 0.12 & 0.01 & 0.04 & 0.13 & 0.36 & 0.03 & 0.08 \\
\hline
\end{tabular}

Robust standard errors in parentheses. $* * *=1 \%, * *=5 \%, *=10 \%$ significance level.

\begin{tabular}{|c|c|c|c|c|c|c|c|c|c|c|c|}
\hline Variable & Denmark & Australia & Belgium & Switzerland & Austria & Finland & Portugal & Ireland & Greece & Luxembourg & New Zealand \\
\hline Voting coincidence $(t-1)$ & $\begin{array}{c}0.2508 \\
(0.0882) * * *\end{array}$ & $\begin{array}{c}0.0687 \\
(0.1126)\end{array}$ & $\begin{array}{c}0.0729 \\
(0.1063)\end{array}$ & $\begin{array}{c}0.1646 \\
(0.1444)\end{array}$ & $\begin{array}{l}-0.0999 \\
(0.1459)\end{array}$ & $\begin{array}{c}0.1652 \\
(0.1224)\end{array}$ & $\begin{array}{c}0.1587 \\
(0.1259)\end{array}$ & $\begin{array}{c}0.0901 \\
(0.1317)\end{array}$ & $\begin{array}{c}0.0949 \\
(0.0674)\end{array}$ & $\begin{array}{c}0.1547 \\
(0.0881)^{*}\end{array}$ & $\begin{array}{c}0.0164 \\
(0.1301)\end{array}$ \\
\hline Level ODA $(t-1)$ & $\begin{array}{c}0.2707 \\
(0.5335)\end{array}$ & $\begin{array}{l}-0.0612 \\
(0.0988)\end{array}$ & $\begin{array}{c}0.0258 \\
(0.0265)\end{array}$ & $\begin{array}{c}0.3948 \\
(0.9006)\end{array}$ & $\begin{array}{l}-0.0584 \\
(0.2197)\end{array}$ & $\begin{array}{c}-2.2697 \\
(1.0101)^{* *}\end{array}$ & $\begin{array}{l}-0.7446 \\
(0.4757)\end{array}$ & $\begin{array}{l}-1.7699 \\
(1.8301)\end{array}$ & $\begin{array}{l}-0.1704 \\
(0.2998)\end{array}$ & $\begin{array}{l}-0.8338 \\
(0.7635)\end{array}$ & $\begin{array}{c}2.0843 \\
(2.9717)\end{array}$ \\
\hline Democracy $(t-1)$ & $\begin{array}{c}2.6348 \\
(2.6548)\end{array}$ & $\begin{array}{l}-0.9583 \\
(2.6631)\end{array}$ & $\begin{array}{l}-0.5834 \\
(3.5051)\end{array}$ & $\begin{array}{c}5.4206 \\
(2.5567)^{* *}\end{array}$ & $\begin{array}{c}10.797 \\
(4.4116)^{* *}\end{array}$ & $\begin{array}{l}0.9213 \\
2.9344\end{array}$ & $\begin{array}{c}0.9987 \\
(3.1736)\end{array}$ & $\begin{array}{c}1.1637 \\
(2.4809)\end{array}$ & $\begin{array}{c}0.9208 \\
(1.9823)\end{array}$ & $\begin{array}{c}3.4637 \\
(3.3889)\end{array}$ & $\begin{array}{c}2.7120 \\
(3.4698)\end{array}$ \\
\hline National Capabilities $(t-1)$ & $\begin{array}{l}-0.6729 \\
(0.8638)\end{array}$ & $\begin{array}{c}1.8749 \\
(2.0534)\end{array}$ & $\begin{array}{c}0.1384 \\
(1.1818)\end{array}$ & $\begin{array}{c}0.0789 \\
(0.9843)\end{array}$ & $\begin{array}{l}-0.0459 \\
(0.2609)\end{array}$ & $\begin{array}{l}-0.8048 \\
(0.8818)\end{array}$ & $\begin{array}{l}-0.9810 \\
(3.0897)\end{array}$ & $\begin{array}{l}-0.0016 \\
(1.0583)\end{array}$ & $\begin{array}{l}-2.4703 \\
(1.8401)\end{array}$ & $\begin{array}{c}0.4442 \\
(1.0704)\end{array}$ & $\begin{array}{l}-1.4392 \\
(0.9246)\end{array}$ \\
\hline $\operatorname{GDPC}(t-1)$ & $\begin{array}{l}-0.0000 \\
(0.0032)\end{array}$ & $\begin{array}{c}0.0007 \\
(0.0036)\end{array}$ & $\begin{array}{c}0.0036 \\
(0.0024)\end{array}$ & $\begin{array}{c}0.0025 \\
(0.0040)\end{array}$ & $\begin{array}{l}-0.0034 \\
(0.0031)\end{array}$ & $\begin{array}{c}0.0034 \\
(0.0026)\end{array}$ & $\begin{array}{c}0.0145 \\
(0.0075)^{*}\end{array}$ & $\begin{array}{c}0.0007 \\
(0.0046)\end{array}$ & $\begin{array}{c}0.0111 \\
(0.0062) *\end{array}$ & $\begin{array}{l}-0.0029 \\
(0.0034)\end{array}$ & $\begin{array}{c}0.0052 \\
(0.0024)\end{array}$ \\
\hline Number of countries & 108 & 64 & 92 & 78 & 102 & 84 & 48 & 84 & 61 & 80 & 65 \\
\hline Number of observations & 1178 & 586 & 917 & 325 & 320 & 864 & 207 & 788 & 347 & 617 & 626 \\
\hline Arellano-Bond test (p-value) & 0.06 & 0.56 & 0.60 & 0.62 & 0.29 & 0.84 & 0.58 & 0.03 & 0.49 & 0.23 & 0.99 \\
\hline Number of instruments & 35 & 54 & 54 & 22 & 54 & 54 & 48 & 54 & 39 & 54 & 54 \\
\hline Hansen J stat. (p-value) & 0.24 & 0.40 & 0.16 & 0.56 & 0.37 & 0.21 & 0.93 & 0.14 & 0.07 & 0.45 & 0.12 \\
\hline
\end{tabular}


Table 3.4: Bilateral Aid and UN Voting for ODA Giving Countries Including GDP Growth (GMM)

\begin{tabular}{|c|c|c|c|c|c|c|c|c|c|c|c|}
\hline Variable & United States & Japan & France & Germany & United Kingdom & m Netherlands & Italy & Canada & Spain & Norway & Sweden \\
\hline Voting coincidence $(t-1)$ & $\begin{array}{c}0.1173 \\
(0.1293)\end{array}$ & $\begin{array}{c}0.0667 \\
(0.1099)\end{array}$ & $\begin{array}{c}0.1125 \\
(0.1075)\end{array}$ & $\begin{array}{c}0.1396 \\
(0.1131)\end{array}$ & $\begin{array}{c}0.1032 \\
(0.1111)\end{array}$ & $\begin{array}{c}0.2141 \\
(00743) * * *\end{array}$ & $\begin{array}{c}0.2151 \\
(0.1137)^{*}\end{array}$ & $\begin{array}{c}0.1709 \\
(0.1059)\end{array}$ & $\begin{array}{c}0.1440 \\
(0.1114)\end{array}$ & $\begin{array}{c}0.1833 \\
(0.0864)^{* *}\end{array}$ & $\begin{array}{c}0.1604 \\
(0.0925)^{*}\end{array}$ \\
\hline Level ODA $(t-1)$ & $\begin{array}{c}0.0001 \\
(0.0001)\end{array}$ & $\begin{array}{c}-0.0012 \\
(0.0005)^{* * *}\end{array}$ & $\begin{array}{c}0.0025 \\
(0.0008) * * *\end{array}$ & $\begin{array}{l}-0.0003 \\
(0.0159)\end{array}$ & $\begin{array}{c}0.0038 \\
(0.0015)^{* * *}\end{array}$ & $\begin{array}{c}0.0424 \\
(0.0519)\end{array}$ & $\begin{array}{c}-0.0949 \\
(0.0357)^{* * *}\end{array}$ & $\begin{array}{c}0.0069 \\
(0.0021)^{* * *}\end{array}$ & $\begin{array}{c}0.0018 \\
(0.0005)^{* * *}\end{array}$ & $\begin{array}{l}-0.6809 \\
(1.1065)\end{array}$ & $\begin{array}{c}0.1623 \\
(0.3189)\end{array}$ \\
\hline Democracy $(t-1)$ & $\begin{array}{l}1.3044 \\
(0.9902\end{array}$ & $\begin{array}{c}0.6421 \\
(2.1886)\end{array}$ & $\begin{array}{c}1.3246 \\
(1.9518)\end{array}$ & $\begin{array}{c}1.8004 \\
(2.1096)\end{array}$ & $\begin{array}{c}2.0212 \\
(2.1135)\end{array}$ & $\begin{array}{c}3.5788 \\
(2.4863)\end{array}$ & $\begin{array}{c}1.8144 \\
(2.4725)\end{array}$ & $\begin{array}{c}2.1788 \\
(2.0350)\end{array}$ & $\begin{array}{c}1.7111 \\
(2.4603)\end{array}$ & $\begin{array}{c}3.0294 \\
(2.6712)\end{array}$ & $\begin{array}{c}4.0215 \\
(2.7664)\end{array}$ \\
\hline National Capabilities $(t-1)$ & $\begin{array}{c}0.7372 \\
(0.9149)\end{array}$ & $\begin{array}{c}0.0889 \\
(0.9412)\end{array}$ & $\begin{array}{l}-0.4548 \\
(0.7909)\end{array}$ & $\begin{array}{l}0.04978 \\
(0.8998)\end{array}$ & $\begin{array}{l}-0.4058 \\
(0.7914)\end{array}$ & $\begin{array}{l}-0.6127 \\
(1.0138)\end{array}$ & $\begin{array}{l}-0.4875 \\
(0.7868)\end{array}$ & $\begin{array}{c}0.4464 \\
(0.8402)\end{array}$ & $\begin{array}{l}-0.7817 \\
(0.8051)\end{array}$ & $\begin{array}{c}0.1462 \\
(1.5984)\end{array}$ & $\begin{array}{l}-1.0692 \\
(1.1345)\end{array}$ \\
\hline GDP Growth $(t-1)$ & $\begin{array}{l}-0.0386 \\
(0.0292)\end{array}$ & $\begin{array}{l}-0.0491 \\
(0.0833)\end{array}$ & $\begin{array}{l}-0.0804 \\
(0.0535)\end{array}$ & $\begin{array}{l}-0.1124 \\
(0.0727)\end{array}$ & $\begin{array}{l}-0.0658 \\
(0.0581)\end{array}$ & $\begin{array}{l}-0.1301 \\
(0.0795)\end{array}$ & $\begin{array}{l}-0.1063 \\
(0.0912)\end{array}$ & $\begin{array}{l}-0.0832 \\
(0.0671)\end{array}$ & $\begin{array}{l}-0.0913 \\
(0.0851)\end{array}$ & $\begin{array}{l}-0.1316 \\
(0.0985)\end{array}$ & $\begin{array}{l}-0.1725 \\
(0.0756)\end{array}$ \\
\hline Number of countries & 95 & 96 & 96 & 96 & 96 & 134 & 95 & 96 & 90 & 123 & 120 \\
\hline Number of observations & 978 & 1021 & 1022 & 1026 & 992 & 1713 & 912 & 1019 & 845 & 1516 & 1511 \\
\hline Arellano-Bond test ( $\mathrm{p}$-value) & 0.20 & 0.60 & 0.98 & 0.55 & 0.98 & 0.19 & 0.74 & 0.52 & 0.60 & 0.05 & 0.40 \\
\hline Number of instuments & 54 & 54 & 54 & 54 & 54 & 35 & 54 & 54 & 54 & 35 & 35 \\
\hline Hansen J stat. (p-value) & 0.42 & 0.57 & 0.11 & 0.16 & 0.16 & 0.01 & 0.06 & 0.18 & 0.26 & 0.05 & 0.06 \\
\hline $\begin{array}{l}\text { andard erro } \\
\text { Variable }\end{array}$ & Denmark & $\begin{array}{c}*=1 \%, * \\
\text { Australia }\end{array}$ & $=5 \%, *=$ & Switzerland & $\begin{array}{l}\text { nce level. } \\
\text { Austria }\end{array}$ & Finland & Portugal & reland & Greece & uxembourg & New Zealand \\
\hline Voting coincidence $(t-1)$ & $\begin{array}{c}0.2609 \\
(0.0868)^{* * *}\end{array}$ & $\begin{array}{c}0.0882 \\
(0.1130)\end{array}$ & $\begin{array}{c}0.0675 \\
(0.1086)\end{array}$ & $\begin{array}{c}0.1461 \\
(0.1661)\end{array}$ & $\begin{array}{l}-0.0554 \\
(0.1725)\end{array}$ & $\begin{array}{c}0.1664 \\
(0.1258)\end{array}$ & $\begin{array}{l}0.1502 \\
(0.1354)\end{array}$ & $\begin{array}{l}0.0947 \\
0.1311)\end{array}$ & $\begin{array}{c}0.0624 \\
(0.0662)\end{array}$ & $\begin{array}{c}0.2001 \\
(0.0994)^{* *}\end{array}$ & $\begin{array}{c}0.0084 \\
(0.1290)\end{array}$ \\
\hline Level ODA $(t-1)$ & $\begin{array}{c}0.4460 \\
(0.6566)\end{array}$ & $\begin{array}{l}-0.0705 \\
(0.0923)\end{array}$ & $\begin{array}{c}0.0335 \\
(0.0264)\end{array}$ & $\begin{array}{c}0.3152 \\
(0.7281)\end{array}$ & $\begin{array}{l}-0.0479 \\
(0.2065)\end{array}$ & $\begin{array}{c}-2.3101 \\
0.9840)^{* *}\end{array}$ & $\begin{array}{l}-0.7459 \\
(0.5109)\end{array}$ & $\begin{array}{l}1.9289 \\
1.6865)\end{array}$ & $\begin{array}{l}-0.2195 \\
(0.3209)\end{array}$ & $\begin{array}{l}-0.9821 \\
(0.7831)\end{array}$ & $\begin{array}{c}1.7258 \\
(3.0917)\end{array}$ \\
\hline Democracy $(t-1)$ & $\begin{array}{c}2.7510 \\
(2.6695)\end{array}$ & $\begin{array}{l}-0.9716 \\
(2.5850)\end{array}$ & $\begin{array}{l}-0.5455 \\
(3.5039)\end{array}$ & $\begin{array}{c}5.5184 \\
(2.5179)^{* *}\end{array}$ & $\begin{array}{c}10.8386 \\
(4.3368)^{* * *}\end{array}$ & $\begin{array}{c}0.9432 \\
(2.8679)\end{array}$ & $\begin{array}{c}0.3436 \\
(3.2956)\end{array}$ & $\begin{array}{l}1.3253 \\
2.3814)\end{array}$ & $\begin{array}{c}0.8615 \\
(1.9442)\end{array}$ & $\begin{array}{c}3.8979 \\
(2.2461)\end{array}$ & $\begin{array}{c}2.6348 \\
(3.5058)\end{array}$ \\
\hline National Capabilities $(t-1)$ & $\begin{array}{l}-0.8702 \\
(1.0397)\end{array}$ & $\begin{array}{c}1.7838 \\
(1.9137)\end{array}$ & $\begin{array}{c}0.7366 \\
(1.2781)\end{array}$ & $\begin{array}{c}0.0327 \\
(0.8003)\end{array}$ & $\begin{array}{l}-0.0580 \\
(0.2829)\end{array}$ & $\begin{array}{l}-0.6000 \\
(0.8522)\end{array}$ & $\begin{array}{c}1.0325 \\
(3.2607)\end{array}$ & $\begin{array}{l}0.0837 \\
0.8438)\end{array}$ & $\begin{array}{l}-1.3814 \\
(1.7738)\end{array}$ & $\begin{array}{c}-0.1692 \\
(0.90419)\end{array}$ & $\begin{array}{l}-0.9129 \\
(0.8768)\end{array}$ \\
\hline GDP Growth $(t-1)$ & $\begin{array}{l}-0.0630 \\
(0.0927)\end{array}$ & $\begin{array}{l}-0.1019 \\
(0.0952)\end{array}$ & $\begin{array}{l}-0.0388 \\
(0.0657)\end{array}$ & $\begin{array}{l}-0.0255 \\
(0.1876)\end{array}$ & $\begin{array}{c}0.3138 \\
(0.0950)^{* * *}\end{array}$ & $\begin{array}{l}-0.0894 \\
(0.0791)\end{array}$ & $\begin{array}{c}0.1439 \\
(0.1322)\end{array}$ & $\begin{array}{l}-0.1306 \\
0.0848)\end{array}$ & $\begin{array}{l}-0.0359 \\
(0.1696)\end{array}$ & $\begin{array}{l}-0.1692 \\
(0.9042)\end{array}$ & $\begin{array}{c}0.0048 \\
(0.1284)\end{array}$ \\
\hline Number of countries & 111 & 66 & 94 & 80 & 104 & 87 & 49 & 86 & 63 & 93 & 67 \\
\hline Number of observations & 1193 & 601 & 924 & 336 & 322 & 878 & 214 & 800 & 355 & 627 & 641 \\
\hline Arellano-Bond test (p-value) & 0.09 & 0.53 & 0.47 & 0.62 & 0.26 & 0.79 & 0.66 & 0.03 & 0.14 & 0.44 & 0.86 \\
\hline Number of instruments & 35 & 54 & 54 & 22 & 54 & 54 & 54 & 54 & 39 & 54 & 54 \\
\hline Hansen J stat. (p-value) & 0.25 & 0.46 & 0.20 & 0.60 & 0.49 & 0.21 & 0.87 & 0.17 & 0.19 & 0.82 & 0.15 \\
\hline
\end{tabular}


Table 3.5: Bilateral Aid and UN Voting for ODA Giving Countries Including External Debt (GMM)

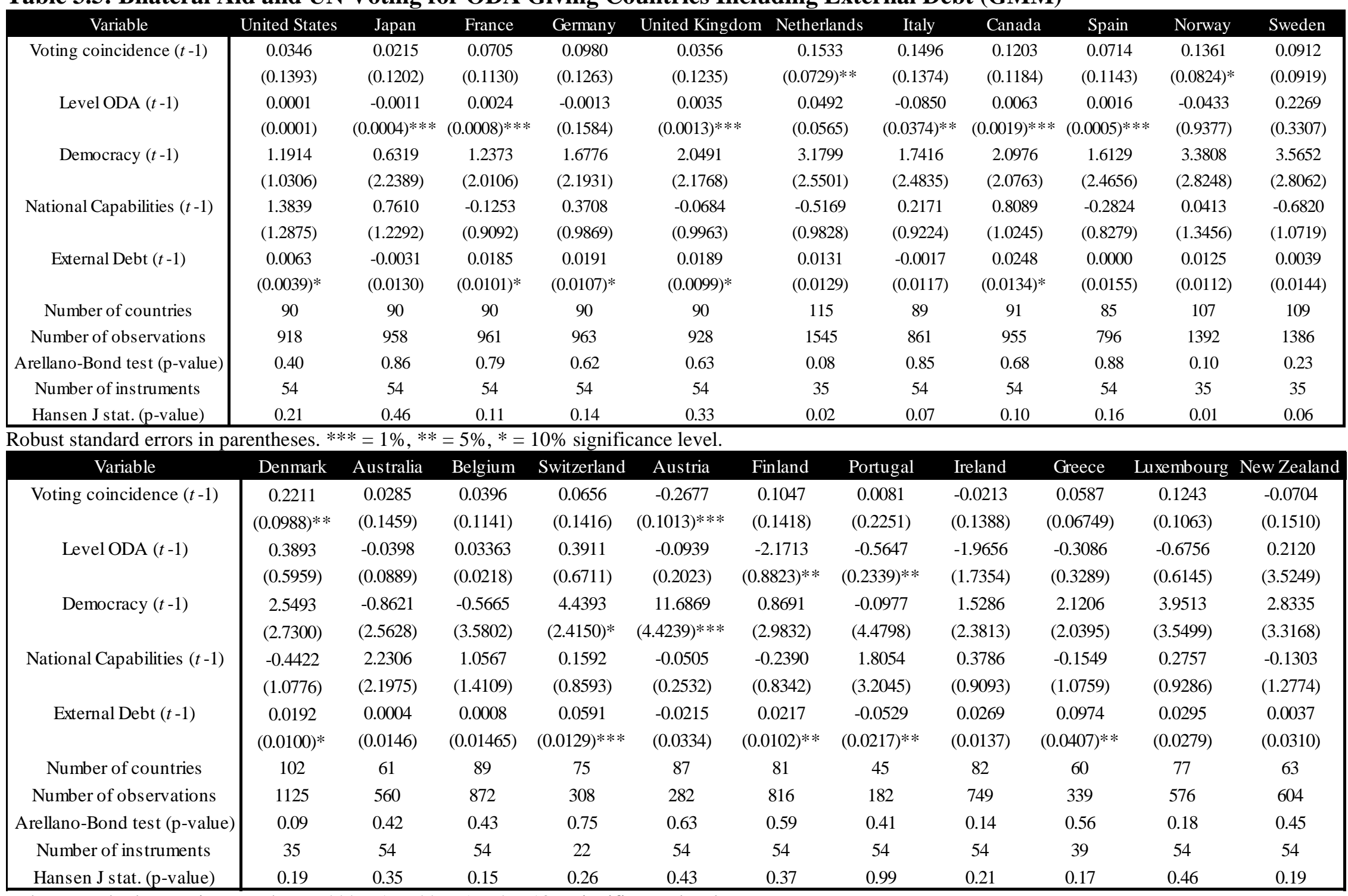

Robust standard errors in parentheses. $* * *=1 \%, * *=5 \%, *=10 \%$ significance level. 
Table 3.6: Bilateral Aid and UN Voting for ODA Giving Countries Including AFPTL (GMM)

\begin{tabular}{|c|c|c|c|c|c|c|c|c|c|c|c|}
\hline Variable & United States & Japan & France & Germany & United Kingdom & Netherlands & Italy & Canada & Spain & Norway & Sweden \\
\hline \multirow[t]{2}{*}{ Voting coincidence $(t-1)$} & 0.1583 & 0.1044 & 0.1406 & 0.1769 & 0.1425 & 0.2415 & 0.2379 & 0.2059 & 0.1363 & 0.2393 & 0.1953 \\
\hline & $(0.1327)$ & $(0.1079)$ & $(0.1067)$ & $(0.1114)$ & $(0.1122)$ & $(0.0776)^{* * *}$ & $(0.1146)^{*}$ & $(0.1067)^{*}$ & $(0.1110)$ & $(0.0895)^{* * *}$ & $(0.0933)^{* *}$ \\
\hline \multirow[t]{2}{*}{ Level ODA $(t-1)$} & 0.0001 & -0.0011 & 0.0025 & 0.0013 & 0.0037 & 0.0297 & -0.0884 & 0.0068 & 0.0017 & -1.6968 & 0.1191 \\
\hline & $(0.0001)$ & $(0.0004)^{* * *}$ & $(0.0008)^{* * *}$ & $(0.0147)$ & $(0.0014)^{* * *}$ & $(0.0389)$ & $(0.0398)^{* *}$ & $(0.0021)^{* * *}$ & $(0.0005) * * *$ & $(1.3442)$ & $(0.3209)$ \\
\hline \multirow[t]{2}{*}{ Democracy $(t-1)$} & 1.2436 & 0.5868 & 1.3040 & 1.7496 & 2.0516 & 3.5658 & 1.8696 & 2.3033 & 1.5496 & 2.5779 & 4.1171 \\
\hline & $(1.0141)$ & $(2.3286)$ & (2.1307) & (2.3619) & (2.2344) & (2.6676) & (2.5837) & (2.2505) & (2.4928) & $(2.9782)$ & (2.9689) \\
\hline \multirow[t]{2}{*}{$\operatorname{AFPTL}(t-1)$} & 0.0208 & -0.0033 & -0.1455 & 0.0242 & -0.1108 & -0.3520 & -0.1789 & 0.1205 & -0.2211 & -0.0521 & -05103 \\
\hline & $(0.1008)$ & $(0.2981)$ & $(0.2191)$ & $(0.2594)$ & $(0.2151)$ & $(0.6692)$ & $(0.2477)$ & $(0.2756)$ & $(0.2287)$ & $(0.4490)$ & $(0.6085)$ \\
\hline Number of countries & 96 & 97 & 98 & 98 & 97 & 134 & 96 & 98 & 91 & 122 & 120 \\
\hline Number of observations & 992 & 994 & 1004 & 1006 & 977 & 1685 & 900 & 999 & 818 & 1476 & 1492 \\
\hline Arellano-Bond test (p-value) & 0.11 & 0.37 & 0.78 & 0.36 & 0.61 & 0.17 & 0.48 & 0.38 & 0.48 & 0.23 & 0.12 \\
\hline Number of instruments & 53 & 53 & 53 & 53 & 53 & 34 & 53 & 53 & 53 & 34 & 34 \\
\hline Hansen J stat. (p-value) & 0.23 & 0.32 & 0.30 & 0.18 & 0.13 & 0.01 & 0.24 & 0.22 & 0.15 & 0.26 & 0.04 \\
\hline
\end{tabular}

Robust standard errors in parentheses. $* * *=1 \%, * *=5 \%, *=10 \%$ significance level.

\begin{tabular}{|c|c|c|c|c|c|c|c|c|c|c|c|}
\hline Variable & Denmark & Australia & Belgium & Switzerland & Austria & Finland & Portugal & Ireland & Greece & Luxembourg & New Zealand \\
\hline \multirow[t]{2}{*}{ Voting coincidence $(t-1)$} & 0.2977 & 0.1270 & 0.1037 & 0.1309 & 0.0032 & 0.1958 & 0.1611 & 0.1147 & 0.0528 & 0.1237 & 0.0629 \\
\hline & $(0.0869) * * *$ & $(0.1299)$ & $(0.1127)$ & $(0.1546)$ & $(0.1510)$ & $(0.1195)^{*}$ & $(0.1272)$ & $(0.1232)$ & $(0.0664)$ & $(0.0804)$ & $(0.1201)$ \\
\hline \multirow[t]{2}{*}{ Level ODA $(t-1)$} & 0.3750 & -0.08603 & 0.0348 & 0.3958 & 0.0392 & -2.4398 & -0.4856 & -1.8205 & -0.2655 & -0.8763 & -0.1679 \\
\hline & $(0.6289)$ & $(0.0719)$ & $(0.0231)$ & $(0.7563)$ & $(0.1874)$ & $(0.9259)^{* * *}$ & $(0.2516)^{*}$ & $(1.7251)$ & $(0.3033)$ & $(0.7925)$ & (3.6756) \\
\hline \multirow[t]{2}{*}{ Democracy $(t-1)$} & 2.7985 & -1.8135 & -0.5053 & 5.1854 & 6.2454 & 0.8725 & 0.4722 & 0.8592 & 0.8921 & 3.3649 & 2.1501 \\
\hline & (2.9044) & (2.9809) & $(3.5538)$ & $(2.9467)^{*}$ & (4.7787) & (2.9949) & (3.2748) & $(2.5389)$ & (1.9453) & (3.3449) & (3.8679) \\
\hline \multirow[t]{2}{*}{$\operatorname{AFPTL}(t-1)$} & 0.1661 & -0.0225 & -0.0919 & 0.0001 & -1.9663 & -0.0536 & -2.1374 & -0.1518 & -1.1500 & -0.2029 & -0.5096 \\
\hline & $(0.3016)$ & $(0.2490)$ & $(0.2314)$ & $(0.2799)$ & $(0.8611)^{* *}$ & $(0.2607)$ & $(1.7412)$ & $(0.2955)$ & $(0.6929)^{*}$ & $(0.3372)$ & $(0.4062)$ \\
\hline Number of countries & 113 & 66 & 96 & 80 & 105 & 89 & 48 & 87 & 64 & 84 & 68 \\
\hline Number of observations & 1158 & 590 & 907 & 310 & 373 & 870 & 205 & 790 & 336 & 617 & 630 \\
\hline Arellano-Bond test ( $\mathrm{p}$-value) & 0.12 & 0.58 & 0.74 & 0.34 & 0.16 & 0.84 & 0.83 & 0.02 & 0.37 & 0.28 & 0.99 \\
\hline Number of instruments & 34 & 53 & 53 & 21 & 53 & 53 & 53 & 53 & 38 & 53 & 53 \\
\hline Hansen J stat. (p-value) & 0.19 & 0.29 & 0.21 & 0.53 & 0.42 & 0.09 & 0.94 & 0.11 & 0.17 & 0.42 & 0.20 \\
\hline
\end{tabular}

Robust standard errors in parentheses. $* * *=1 \%, * *=5 \%, *=10 \%$ significance level. 
Table 3.7: Bilateral Aid and UN Voting for ODA Giving Countries Including Imports (GMM)

\begin{tabular}{|c|c|c|c|c|c|c|c|c|c|c|c|}
\hline Variable & United States & Japan & France & Germany & United Kingdom & Netherlands & Italy & Canada & Spain & Norway & Sweden \\
\hline Voting coincidence $(t-1)$ & $\begin{array}{c}0.0507 \\
(0.1425)\end{array}$ & $\begin{array}{l}-0.0052 \\
(0.1135)\end{array}$ & $\begin{array}{c}0.0593 \\
(0.1114)\end{array}$ & $\begin{array}{c}0.0642 \\
(0.1160)\end{array}$ & $\begin{array}{c}0.0391 \\
(0.1144)\end{array}$ & $\begin{array}{c}0.1859 \\
(0.0797)^{* *}\end{array}$ & $\begin{array}{c}0.1507 \\
(0.1236)\end{array}$ & $\begin{array}{c}0.0727 \\
(0.1059)\end{array}$ & $\begin{array}{c}0.1005 \\
(0.1193)\end{array}$ & $\begin{array}{c}0.1412 \\
(0.0968)\end{array}$ & $\begin{array}{c}0.1237 \\
(0.1029)\end{array}$ \\
\hline Level ODA $(t-1)$ & $\begin{array}{c}0.0001 \\
(0.0001)\end{array}$ & $\begin{array}{c}-0.0010 \\
(0.0005)^{* *}\end{array}$ & $\begin{array}{c}0.0026 \\
(0.0007)^{* * *}\end{array}$ & $\begin{array}{l}-0.0016 \\
(0.0159)\end{array}$ & $\begin{array}{c}0.0031 \\
(0.0016)^{* *}\end{array}$ & $\begin{array}{c}0.0014 \\
(0.0021)\end{array}$ & $\begin{array}{c}-0.0836 \\
(0.0337)^{* * *}\end{array}$ & $\begin{array}{c}0.0065 \\
(0.0021)^{* * *}\end{array}$ & $\begin{array}{c}0.0017 \\
(0.0005)^{* * *}\end{array}$ & $\begin{array}{l}-0.2393 \\
(0.1678)\end{array}$ & $\begin{array}{c}0.0148 \\
(0.0121)\end{array}$ \\
\hline Democracy $(t-1)$ & $\begin{array}{c}1.5166 \\
(1.0301)\end{array}$ & $\begin{array}{c}0.4832 \\
(2.2848)\end{array}$ & $\begin{array}{c}1.1752 \\
(2.0449)\end{array}$ & $\begin{array}{c}1.5869 \\
(2.1817)\end{array}$ & $\begin{array}{c}2.3527 \\
(2.2339)\end{array}$ & $\begin{array}{c}3.7753 \\
(2.5756)\end{array}$ & $\begin{array}{c}1.9007 \\
(2.5419)\end{array}$ & $\begin{array}{c}1.8686 \\
(2.0903)\end{array}$ & $\begin{array}{c}1.4849 \\
(2.5273)\end{array}$ & $\begin{array}{c}3.5471 \\
(2.7396)\end{array}$ & $\begin{array}{c}4.1075 \\
(2.8183)\end{array}$ \\
\hline National Capabilities $(t-1)$ & $\begin{array}{c}1.5046 \\
(1.2915)\end{array}$ & $\begin{array}{l}-0.1035 \\
(0.9481)\end{array}$ & $\begin{array}{l}-0.3911 \\
(0.8096)\end{array}$ & $\begin{array}{l}-0.1266 \\
(1.1201)\end{array}$ & $\begin{array}{l}-0.4589 \\
(0.7452)\end{array}$ & $\begin{array}{l}-0.5718 \\
(0.9944)\end{array}$ & $\begin{array}{l}-0.4689 \\
(0.8193)\end{array}$ & $\begin{array}{c}0.5239 \\
(0.8693)\end{array}$ & $\begin{array}{l}-1.0318 \\
(0.8873)\end{array}$ & $\begin{array}{c}0.2816 \\
(1.1883)\end{array}$ & $\begin{array}{l}-0.6951 \\
(1.0488)\end{array}$ \\
\hline Imports $(t-1)$ & $\begin{array}{l}-0.0002 \\
(0.0001)\end{array}$ & $\begin{array}{l}-0.0003 \\
(0.0002)\end{array}$ & $\begin{array}{c}0.0002 \\
(0.0009)\end{array}$ & $\begin{array}{l}-0.0001 \\
(0.0004)\end{array}$ & $\begin{array}{l}-0.0007 \\
(0.0005)\end{array}$ & $\begin{array}{c}0.0002 \\
(0.0004)\end{array}$ & $\begin{array}{c}0.0011 \\
(0.0009)\end{array}$ & $\begin{array}{l}-0.0022 \\
(0.0020)\end{array}$ & $\begin{array}{l}-0.0018 \\
(0.0018)\end{array}$ & $\begin{array}{l}-0.0061 \\
(0.0034)\end{array}$ & $\begin{array}{l}-0.0000 \\
(0.0024)\end{array}$ \\
\hline Number of countries & 78 & 78 & 78 & 78 & 78 & 112 & 77 & 78 & 73 & 101 & 98 \\
\hline Number of observations & 806 & 839 & 847 & 844 & 811 & 1400 & 751 & 828 & 707 & 1245 & 1220 \\
\hline Arellano-Bond test ( $\mathrm{p}$-value) & 0.17 & 0.75 & 0.99 & 0.65 & 0.89 & 0.12 & 0.84 & 0.61 & 0.63 & 0.03 & 0.18 \\
\hline Number of instruments & 54 & 54 & 54 & 54 & 54 & 50 & 54 & 54 & 54 & 50 & 50 \\
\hline Hansen J stat. (p-value) & 0.43 & 0.69 & 0.28 & 0.38 & 0.25 & 0.13 & 0.31 & 0.15 & 0.30 & 0.28 & 0.16 \\
\hline
\end{tabular}

Robust standard errors in parentheses. $* * *=1 \%, * *=5 \%, *=10 \%$ significance level.

\begin{tabular}{|c|c|c|c|c|c|c|c|c|c|c|c|}
\hline Variable & Denmark & Australia & Belgium & Switzerland & Austria & Finland & Portugal & Ireland & Greece & Luxembourg & New Zealand \\
\hline Voting coincidence $(t-1)$ & $\begin{array}{c}0.2015 \\
(0.0909)^{* *}\end{array}$ & $\begin{array}{c}0.0715 \\
(0.1208)\end{array}$ & $\begin{array}{c}0.0964 \\
(0.1469)\end{array}$ & $\begin{array}{c}0.1225 \\
(0.1761)\end{array}$ & $\begin{array}{l}-0.1091 \\
(0.1416)\end{array}$ & $\begin{array}{c}0.0784 \\
(0.1213)\end{array}$ & $\begin{array}{c}0.1779 \\
(0.1569)\end{array}$ & $\begin{array}{l}-0.0749 \\
(0.1213)\end{array}$ & $\begin{array}{c}0.0783 \\
(0.0847)\end{array}$ & $\begin{array}{c}0.1110 \\
(0.1025)\end{array}$ & $\begin{array}{l}-0.0013 \\
(0.1350)\end{array}$ \\
\hline Level ODA $(t-1)$ & $\begin{array}{l}-0.1036 \\
(0.0945)\end{array}$ & $\begin{array}{l}-0.0786 \\
(0.0724)\end{array}$ & $\begin{array}{l}-0.1578 \\
(0.2327)\end{array}$ & $\begin{array}{c}0.1429 \\
(1.6622)\end{array}$ & $\begin{array}{l}-0.1235 \\
(0.2209)\end{array}$ & $\begin{array}{c}-2.4645 \\
(0.7010)^{* * * *}\end{array}$ & $\begin{array}{c}-0.5833 \\
(0.2419)^{* *}\end{array}$ & $\begin{array}{c}-2.6753 \\
(0.9108)^{* * *}\end{array}$ & $\begin{array}{l}-0.1065 \\
(0.2464)\end{array}$ & $\begin{array}{l}-0.2341 \\
(1.7912)\end{array}$ & $\begin{array}{c}0.8533 \\
(2.6932)\end{array}$ \\
\hline Democracy $(t-1)$ & $\begin{array}{c}2.8989 \\
(2.6266)\end{array}$ & $\begin{array}{l}-2.0019 \\
(2.9029)\end{array}$ & $\begin{array}{l}-2.1322 \\
(4.2636)\end{array}$ & $\begin{array}{c}4.3672 \\
(2.6959)\end{array}$ & $\begin{array}{c}11.7087 \\
(4.5504)^{* * *}\end{array}$ & $\begin{array}{c}1.0790 \\
(3.0885)\end{array}$ & $\begin{array}{l}-0.6479 \\
(5.3539)\end{array}$ & $\begin{array}{c}1.9319 \\
(2.2685)\end{array}$ & $\begin{array}{c}0.4295 \\
(2.1758)\end{array}$ & $\begin{array}{c}14.3302 \\
(5.1336) * * *\end{array}$ & $\begin{array}{c}2.9715 \\
(3.7067)\end{array}$ \\
\hline National Capabilities $(t-1)$ & $\begin{array}{c}0.4832 \\
(1.1407 /\end{array}$ & $\begin{array}{c}1.9219 \\
(2.1950)\end{array}$ & $\begin{array}{l}-0.0167 \\
(1.2651)\end{array}$ & $\begin{array}{l}-0.4585 \\
(1.1672)\end{array}$ & $\begin{array}{l}-0.0763 \\
(0.2721)\end{array}$ & $\begin{array}{l}-0.1157 \\
(0.8178)\end{array}$ & $\begin{array}{c}1.6804 \\
(4.0940)\end{array}$ & $\begin{array}{l}-0.0709 \\
(0.9067)\end{array}$ & $\begin{array}{l}-2.9824 \\
(3.1889)\end{array}$ & $\begin{array}{l}-0.1169 \\
(1.1537)\end{array}$ & $\begin{array}{l}-0.7611 \\
(0.9374)\end{array}$ \\
\hline Imports $(t-1)$ & $\begin{array}{l}-0.0039 \\
(1.1408)\end{array}$ & $\begin{array}{c}1.6361 \\
(1.0215)\end{array}$ & $\begin{array}{c}-0.0304 \\
(0.08540)\end{array}$ & $\begin{array}{c}0.0033 \\
(0.0492)\end{array}$ & $\begin{array}{l}-7.3872 \\
(8.5381)\end{array}$ & $\begin{array}{c}-0.2899 \\
(0.0869)^{* * * *}\end{array}$ & $\begin{array}{c}0.0062 \\
(0.0375)\end{array}$ & $\begin{array}{c}-0.4459 \\
(0.1029) * * *\end{array}$ & $\begin{array}{l}-0.7339 \\
(0.8928)\end{array}$ & $\begin{array}{l}-0.0144 \\
(0.0124)\end{array}$ & $\begin{array}{c}-9.9162 \\
8.5511\end{array}$ \\
\hline Number of countries & 91 & 57 & 82 & 66 & 97 & 70 & 41 & 72 & 50 & 58 & 58 \\
\hline Number of observations & 1001 & 509 & 565 & 274 & 313 & 723 & 180 & 652 & 285 & 319 & 565 \\
\hline Arellano-Bond test (p-value) & 0.06 & 0.30 & 0.22 & 0.45 & 0.26 & 0.81 & 0.78 & 0.10 & 0.83 & 0.57 & 0.72 \\
\hline Number of instruments & 50 & 54 & 37 & 22 & 54 & 54 & 54 & 54 & 39 & 54 & 54 \\
\hline Hansen J stat. (p-value) & 0.34 & 0.43 & 0.23 & 0.44 & 0.36 & 0.24 & 0.98 & 0.09 & 0.10 & 0.42 & 0.32 \\
\hline
\end{tabular}

Robust standard errors in parentheses. $* * *=1 \%, * *=5 \%, *=10 \%$ significance level. 
Table 3.8: Bilateral Aid and UN Voting for ODA Giving Countries Including Exports (GMM)

\begin{tabular}{|c|c|c|c|c|c|c|c|c|c|c|c|}
\hline Variable & United States & Japan & France & Germany & United Kingdom & Netherlands & Italy & Canada & Spain & Norway & Sweden \\
\hline Voting coincidence $(t-1)$ & $\begin{array}{c}0.0483 \\
(0.1425)\end{array}$ & $\begin{array}{l}-0.0052 \\
(0.1136)\end{array}$ & $\begin{array}{c}0.0591 \\
(0.1114)\end{array}$ & $\begin{array}{c}0.0652 \\
(0.1164)\end{array}$ & $\begin{array}{c}0.0387 \\
(0.1141)\end{array}$ & $\begin{array}{c}0.1855 \\
(0.0789)^{* *}\end{array}$ & $\begin{array}{c}0.1454 \\
(0.1222)\end{array}$ & $\begin{array}{c}0.0738 \\
(0.1112)\end{array}$ & $\begin{array}{c}0.1017 \\
(0.1205)\end{array}$ & $\begin{array}{c}0.1411 \\
(0.0973)\end{array}$ & $\begin{array}{c}0.1231 \\
(01028)\end{array}$ \\
\hline Level ODA $(t-1)$ & $\begin{array}{c}0.0001 \\
(0.0001)\end{array}$ & $\begin{array}{c}-0.0010 \\
(0.0005)^{* *}\end{array}$ & $\begin{array}{c}0.0026 \\
(0.0008)^{* * *}\end{array}$ & $\begin{array}{l}-0.0016 \\
(0.0159)\end{array}$ & $\begin{array}{c}0.0031 \\
(0.0016)^{* *}\end{array}$ & $\begin{array}{c}0.0014 \\
(0.0021)\end{array}$ & $\begin{array}{c}-0.0824 \\
(0.0340)^{* * *}\end{array}$ & $\begin{array}{c}0.0065 \\
(0.0021)^{* * *}\end{array}$ & $\begin{array}{c}0.0017 \\
(0.0005)^{* * *}\end{array}$ & $\begin{array}{l}-0.2383 \\
(0.1675)\end{array}$ & $\begin{array}{c}0.0149 \\
(0.0122)\end{array}$ \\
\hline Democracy $(t-1)$ & $\begin{array}{c}1.4409 \\
(1.0300)\end{array}$ & $\begin{array}{c}0.4779 \\
(2.2873)\end{array}$ & $\begin{array}{c}1.1811 \\
(2.0501)\end{array}$ & $\begin{array}{c}1.5373 \\
(2.1805)\end{array}$ & $\begin{array}{c}2.3677 \\
(2.2344)\end{array}$ & $\begin{array}{l}3.7870 \\
(2.5779)\end{array}$ & $\begin{array}{c}2.1581 \\
(2.5506)\end{array}$ & $\begin{array}{c}1.8386 \\
(2.0852)\end{array}$ & $\begin{array}{c}1.4305 \\
(2.5184)\end{array}$ & $\begin{array}{c}3.5517 \\
(2.7453)\end{array}$ & $\begin{array}{c}4.1456 \\
(2.8268)\end{array}$ \\
\hline National Capabilities $(t-1)$ & $\begin{array}{c}1.4987 \\
(1.2954)\end{array}$ & $\begin{array}{l}-0.1139 \\
(0.9482)\end{array}$ & $\begin{array}{l}-0.3900 \\
(0.8089)\end{array}$ & $\begin{array}{l}-0.1316 \\
(1.1214)\end{array}$ & $\begin{array}{l}-0.4626 \\
(0.7427)\end{array}$ & $\begin{array}{l}-0.5697 \\
(0.9949)\end{array}$ & $\begin{array}{l}-0.4627 \\
(0.8167)\end{array}$ & $\begin{array}{c}0.5446 \\
(0.8778)\end{array}$ & $\begin{array}{l}-1.0348 \\
(0.8881)\end{array}$ & $\begin{array}{c}0.2798 \\
(1.1898)\end{array}$ & $\begin{array}{l}-0.6902 \\
(1.0494)\end{array}$ \\
\hline Exports $(t-1)$ & $\begin{array}{c}-0.0005 \\
(0.0001)^{* * *}\end{array}$ & $\begin{array}{c}-0.0005 \\
(0.0003)^{*}\end{array}$ & $\begin{array}{l}-0.0006 \\
(0.0026)\end{array}$ & $\begin{array}{l}-0.0017 \\
(0.0013)\end{array}$ & $\begin{array}{l}-0.0084 \\
(0.0071)\end{array}$ & $\begin{array}{c}0.0035 \\
(0.0133)\end{array}$ & $\begin{array}{c}0.0048 \\
(0.0042)\end{array}$ & $\begin{array}{l}-0.0090 \\
(0.0073)\end{array}$ & $\begin{array}{l}-0.0025 \\
(0.0059)\end{array}$ & $\begin{array}{l}-0.0019 \\
(0.0203)\end{array}$ & $\begin{array}{c}0.0132 \\
(0.0178)\end{array}$ \\
\hline Number of countries & 78 & 78 & 78 & 78 & 78 & 112 & 77 & 78 & 73 & 101 & 98 \\
\hline Number of observations & 806 & 838 & 847 & 844 & 811 & 1400 & 751 & 826 & 707 & 1244 & 1220 \\
\hline Arellano-Bond test ( $\mathrm{p}$-value) & 0.18 & 0.74 & 0.99 & 0.64 & 0.89 & 0.12 & 0.85 & 0.60 & 0.63 & 0.03 & 0.18 \\
\hline Number of instruments & 54 & 54 & 54 & 54 & 54 & 50 & 54 & 54 & 54 & 50 & 50 \\
\hline Hansen J stat. (p-value) & 0.41 & 0.68 & 0.28 & 0.38 & 0.27 & 0.13 & 0.31 & 0.14 & 0.29 & 0.30 & 0.14 \\
\hline
\end{tabular}

Robust standard errors in parentheses. $* * *=1 \%, * *=5 \%, *=10 \%$ significance level.

\begin{tabular}{|c|c|c|c|c|c|c|c|c|c|c|c|}
\hline Variable & Denmark & Australia & Belgium & Switzerland & Austria & Finland & Portugal & Ireland & Greece & Luxembourg & New Zealand \\
\hline Voting coincidence $(t-1)$ & $\begin{array}{c}0.2024 \\
(0.0909)^{* *}\end{array}$ & $\begin{array}{c}0.0747 \\
(0.1198)\end{array}$ & $\begin{array}{c}0.1046 \\
(0.1485)\end{array}$ & $\begin{array}{c}0.1226 \\
(0.1840)\end{array}$ & $\begin{array}{l}-0.1073 \\
(0.1599)\end{array}$ & $\begin{array}{c}0.0734 \\
(0.1222)\end{array}$ & $\begin{array}{c}0.1511 \\
(0.1478)\end{array}$ & $\begin{array}{l}-0.0272 \\
(0.1406)\end{array}$ & $\begin{array}{c}0.0749 \\
(0.0852)\end{array}$ & $\begin{array}{c}0.1064 \\
(0.1024)\end{array}$ & $\begin{array}{l}-0.0200 \\
(0.1483)\end{array}$ \\
\hline Level ODA $(t-1)$ & $\begin{array}{l}-0.1013 \\
(0.0923)\end{array}$ & $\begin{array}{l}-0.0925 \\
(0.0743)\end{array}$ & $\begin{array}{l}-0.1754 \\
(0.2386)\end{array}$ & $\begin{array}{c}0.1061 \\
(1.5939)\end{array}$ & $\begin{array}{l}-0.1141 \\
(0.2151)\end{array}$ & $\begin{array}{c}-2.5020 \\
(0.6981)^{* * *}\end{array}$ & $\begin{array}{c}-0.5872 \\
(0.2143) * * *\end{array}$ & $\begin{array}{c}-2.3909 \\
(1.2824)^{*}\end{array}$ & $\begin{array}{l}-0.1285 \\
(0.2371)\end{array}$ & $\begin{array}{l}-1.1348 \\
(1.6939)\end{array}$ & $\begin{array}{c}0.6634 \\
(3.4021)\end{array}$ \\
\hline Democracy $(t-1)$ & $\begin{array}{c}2.8779 \\
(2.6257)\end{array}$ & $\begin{array}{l}-1.9757 \\
(2.8955)\end{array}$ & $\begin{array}{l}-2.2472 \\
(4.1164)\end{array}$ & $\begin{array}{c}4.2919 \\
(2.7631)\end{array}$ & $\begin{array}{c}11.3539 \\
(4.6304)^{* *}\end{array}$ & $\begin{array}{c}0.9978 \\
(3.0808)\end{array}$ & $\begin{array}{c}0.6552 \\
(5.1009)\end{array}$ & $\begin{array}{c}1.6682 \\
(2.3918)\end{array}$ & $\begin{array}{c}0.2304 \\
(2.1623)\end{array}$ & $\begin{array}{c}14.0156 \\
(5.0174) * * *\end{array}$ & $\begin{array}{c}2.8907 \\
(3.5272)\end{array}$ \\
\hline National Capabilities $(t-1)$ & $\begin{array}{c}0.4717 \\
(1.1358)\end{array}$ & $\begin{array}{c}1.8425 \\
(2.0883)\end{array}$ & $\begin{array}{c}0.0535 \\
(1.2947)\end{array}$ & $\begin{array}{l}-0.4619 \\
(1.1473)\end{array}$ & $\begin{array}{l}-0.0729 \\
(0.2756)\end{array}$ & $\begin{array}{l}-0.2227 \\
(0.8071)\end{array}$ & $\begin{array}{c}1.1129 \\
(4.1734)\end{array}$ & $\begin{array}{c}0.2139 \\
(0.9187)\end{array}$ & $\begin{array}{l}-2.8969 \\
(3.1303)\end{array}$ & $\begin{array}{l}-0.2468 \\
(1.2069)\end{array}$ & $\begin{array}{l}-0.4358 \\
(0.9426)\end{array}$ \\
\hline Exports $(t-1)$ & $\begin{array}{l}-0.0210 \\
(0.0189)\end{array}$ & $\begin{array}{c}1.7861 \\
(0.3342)^{* * *}\end{array}$ & $\begin{array}{c}2.1372 \\
(1.1779)^{*}\end{array}$ & $\begin{array}{l}-0.0001 \\
(0.0222)\end{array}$ & $\begin{array}{l}-1.1159 \\
(6.8445)\end{array}$ & $\begin{array}{c}-0.4081 \\
(0.0709)^{* * *}\end{array}$ & $\begin{array}{c}0.2556 \\
(0.1669)\end{array}$ & $\begin{array}{c}-0.0840 \\
(0.0258) * * *\end{array}$ & $\begin{array}{c}-1.2645 \\
(0.5368) * *\end{array}$ & $\begin{array}{l}-0.0945 \\
(0.2687)\end{array}$ & $\begin{array}{l}-0.0414 \\
(0.0853)\end{array}$ \\
\hline Number of countries & 91 & 57 & 82 & 66 & 97 & 70 & 41 & 72 & 50 & 58 & 55 \\
\hline Number of observations & 1001 & 509 & 565 & 274 & 313 & 723 & 180 & 651 & 285 & 319 & 498 \\
\hline Arellano-Bond test (p-value) & 0.06 & 0.38 & 0.23 & 0.45 & 0.30 & 0.76 & 0.58 & 0.06 & 0.98 & 0.61 & 0.78 \\
\hline Number of instruments & 50 & 54 & 37 & 22 & 54 & 54 & 54 & 54 & 39 & 54 & 54 \\
\hline Hansen J stat. (p-value) & 0.34 & 0.22 & 0.18 & 0.44 & 0.33 & 0.23 & 0.95 & 0.04 & 0.10 & 0.45 & 0.35 \\
\hline
\end{tabular}

Robust standard errors in parentheses. $* * *=1 \%, * *=5 \%, *=10 \%$ significance level. 
The annual data is also converted into six 3 year averaged observations per country to analyze longer term trends in changes to voting coincidence. Three year averages are used because averaging over the full sample "could result in a loss of temporal information, where the results would be driven solely by cross-country variations" (Grier 1997). The results of the basic model confirm the positive relationship between voting coincidence and foreign aid distribution for Canada, France, Spain, and the United Kingdom. ${ }^{46}$ They also show some different results: Belgium, Ireland, New Zealand, Portugal, and the United States have positive coefficients on the variable of interest ${ }^{47}$ while the negative coefficients on the variable of interest for Finland and Italy turn statistically insignificant.

\subsection{Conclusion}

This paper extends the research on the political influence of aid donors, specifically the relationship between foreign aid distribution and its impact on voting coincidence in the UN General Assembly, by empirically analyzing all 22 DAC countries instead of just the United States where much of the former research focused. This extension was chosen because the DAC countries are the primary donors of foreign aid and are the major countries responsible for achieving the Millennium Development Goals. The estimation procedure uses an instrument variable approach and GMM estimation to account to the possible endogenous nature of foreign aid. The time period (post Cold War) was chosen to isolate the changing nature of foreign aid after the end of the Cold War.

\footnotetext{
${ }^{46}$ It is interesting to note that of the seven DAC countries who tied more aid than the DAC average during the sample period, only Canada, France, and Spain show a robust relationship between voting coincidence and foreign aid distribution.

${ }^{47}$ The p-value of the Arellano-Bond test of second order autocorrelation is 0.07 and 0.05 for Ireland and Portugal respectively casting some suspicion on the results.
} 
The results demonstrate that of the non-Nordic countries considered, Canada, France, Spain, and the United Kingdom exhibit a positive relationship between voting coincidence and foreign aid distribution while no conclusive link could be established for the largest aid donor, the United States (foreign aid only positively affects voting coincidence when longer term trends are analyzed). The results are robust to the inclusion of measures of economic power, dependence on foreign support, and international trade patterns. The measurements of "hard" power were generally shown to be statistically insignificant though the measure of external debt did provide evidence that a country more indebted is more likely to increase its voting coincidence with aid donors. Whether a country was a democracy or not also increased a country's voting coincidence with aid donors, though this result was more limited.

The possibility of the results acting as a lower bound of political influence because of free riding provides some possible future research opportunities. Do donor countries seek to maximize their international influence across multiple international organizations or do they focus on only one? If donors attempt to maximize their influence in many organizations, why and how do the donor countries choose one organization over another? Also, is there an optimal strategy to maximize total political influence? Does a country free ride in securing influence in one organization so they can devote their resources to influencing another organization? Does the possibility of free riding affect the behavior of donors in how much aid they give?

The normative policy conclusions from the results are not entirely clear. What is clear is the slow progress of aid donors putting the needs of aid recipients first should serve as a caution to any demand that foreign aid should not be used for the political purposes of the aid donor countries. Even the goal of fulfilling the MDGs does not guarantee aid donors will reform. Aid practice reform may be difficult to adopt because reform may not be in the best interest of aid 
donors, especially if aid donors derive utility from the political gain of aid donations rather than humanitarian goodwill and countries can free ride off the foreign aid practices of other countries. Rather than large changes in the purpose of aid, increasing the transparency of aid practices may be the most reasonable and effective goal for aid reformers to pursue. 
Table 3.9: Average Voting Coincidence Rates Among Development Assistance Committee Countries from 1991 to 2008

\begin{tabular}{|c|c|c|c|c|c|c|c|c|c|c|c|c|c|c|c|c|c|c|c|c|c|c|}
\hline Australia & $\begin{array}{c}\text { Australie } \\
1.00\end{array}$ & Austria & Belgium & Canad & Denmark & Finland & France & Germany & Greece & Ireland & Italy & Japan & Luxembou & Jetherlan & ew Zeal & Norway & Portugal & Spain & Sweder & Witzerlar & inted K & Inited S \\
\hline Austria & 0.84 & 1.00 & & & & & & & & & & & & & & & & & & & & \\
\hline Belgium & 0.81 & 0.92 & 1.00 & & & & & & & & & & & & & & & & & & & \\
\hline Canada & 0.86 & 0.86 & 0.87 & 1.00 & & & & & & & & & & & & & & & & & & \\
\hline Denmark & 0.82 & 0.93 & 0.95 & 0.88 & 1.00 & & & & & & & & & & & & & & & & & \\
\hline Finland & 0.83 & 0.94 & 0.95 & 0.89 & 0.95 & 1.00 & & & & & & & & & & & & & & & & \\
\hline France & 0.72 & 0.82 & 0.86 & 0.76 & 0.83 & 0.83 & 1.00 & & & & & & & & & & & & & & & \\
\hline Germany & 0.80 & 0.91 & 0.97 & 0.87 & 0.94 & 0.95 & 0.85 & 1.00 & & & & & & & & & & & & & & \\
\hline Greece & 0.78 & 0.88 & 0.87 & 0.80 & 0.89 & 0.88 & 0.78 & 0.87 & 1.00 & & & & & & & & & & & & & \\
\hline Ireland & 0.82 & 0.95 & 0.89 & 0.83 & 0.91 & 0.91 & 0.81 & 0.90 & 0.87 & 1.00 & & & & & & & & & & & & \\
\hline Italy & 0.81 & 0.93 & 0.96 & 0.87 & 0.95 & 0.94 & 0.85 & 0.96 & 0.88 & 0.91 & 1.00 & & & & & & & & & & & \\
\hline Japan & 0.79 & 0.87 & 0.84 & 0.82 & 0.87 & 0.86 & 0.74 & 0.84 & 0.80 & 0.85 & 0.85 & 1.00 & & & & & & & & & & \\
\hline Luxembourg & 0.81 & 0.92 & 0.98 & 0.88 & 0.96 & 0.96 & 0.86 & 0.97 & 0.88 & 0.90 & 0.96 & 0.85 & 1.00 & & & & & & & & & \\
\hline Netherlands & 0.80 & 0.91 & 0.97 & 0.88 & 0.96 & 0.95 & 0.85 & 0.97 & 0.87 & 0.89 & 0.96 & 0.85 & 0.97 & 1.00 & & & & & & & & \\
\hline New Zealand & 0.86 & 0.89 & 0.85 & 0.82 & 0.87 & 0.87 & 0.76 & 0.84 & 0.82 & 0.91 & 0.85 & 0.84 & 0.85 & 0.85 & 1.00 & & & & & & & \\
\hline Norway & 0.82 & 0.92 & 0.93 & 0.88 & 0.95 & 0.94 & 0.81 & 0.92 & 0.87 & 0.90 & 0.93 & 0.85 & 0.94 & 0.93 & 0.96 & 1.00 & & & & & & \\
\hline Portugal & 0.83 & 0.93 & 0.94 & 0.86 & 0.95 & 0.93 & 0.83 & 0.94 & 0.90 & 0.92 & 0.96 & 0.85 & 0.94 & 0.94 & 0.86 & 0.93 & 1.00 & & & & & \\
\hline Spain & 0.82 & 0.92 & 0.92 & 0.84 & 0.93 & 0.90 & 0.83 & 0.91 & 0.92 & 0.90 & 0.93 & 0.84 & 0.92 & 0.91 & 0.85 & 0.91 & 0.95 & 1.00 & & & & \\
\hline Sweden & 0.82 & 0.95 & 0.91 & 0.86 & 0.93 & 0.94 & 0.80 & 0.91 & 0.86 & 0.95 & 0.91 & 0.87 & 0.92 & 0.91 & 0.90 & 0.92 & 0.91 & 0.89 & 1.00 & & & \\
\hline Switzerland & 0.75 & 0.95 & 0.93 & 0.81 & 0.93 & 0.95 & 0.83 & 0.94 & 0.92 & 0.93 & 0.94 & 0.86 & 0.94 & 0.94 & 0.90 & 0.94 & 0.92 & 0.92 & 0.92 & 1.00 & & \\
\hline United Kingdom & 0.71 & 0.80 & 0.85 & 0.77 & 0.84 & 0.83 & 0.90 & 0.85 & 0.76 & 0.79 & 0.84 & 0.75 & 0.85 & 0.86 & 0.75 & 0.82 & 0.83 & 0.81 & 0.80 & 0.81 & 1.00 & \\
\hline United States & 0.38 & 0.36 & 0.39 & 0.40 & 0.39 & 0.37 & 0.44 & 0.39 & 0.33 & 0.34 & 0.39 & 0.33 & 0.39 & 0.40 & 0.32 & 0.38 & 0.38 & 0.37 & 0.36 & 0.29 & 0.51 & 1.00 \\
\hline
\end{tabular}

Note: Values range from 0.00 to 1.00 with a value of 0.00 interpreted as the two countries never voting in agreement and a value of 1.00 interpreted as two countries voting in full agreement. 


\section{Chapter 4}

\section{Political Influence and Development Assistance: A Disaggregated Analysis of Development Assistance Distribution and the Development Assistance Committee Countries}

\subsection{Introduction}

Aid donors often cite economic growth, poverty reduction, and social development as the primary reasons for development assistance (Thiele et al. 2007) even though donor intention plays a large role in the distribution of aid (Maizel and Nissanke 1984, White and Morrissey 1997, and Alesina and Dollar 2000). While donor intention can be philanthropic ${ }^{48}$, such as achieving the Millennium Development Goals (MDGs) or fulfilling pledges to give 0.7 percent of national income to development assistance, actual donor behavior insinuates donors are less altruistic then they claim and often grant aid for political reasons (Meernik et al. 1998 and Langhammer 2004). Donor intention has included furthering foreign policy objectives (Zimmerman 1993, Ruttan 1996, and Boschini and Olofsgard 2001), fighting terrorism (Harrigan et al. 2006), and influencing political relationships (Rai 1980 and Kuziemko and Werker 2006).

The effectiveness of development aid "directing" the political relationship between aid donor and recipient is explored extensively in the literature. Research has explored how donors use development aid for political purposes in international organizations like the IMF and World Bank (Oatley and Yackee 2004, Barro and Lee 2005, and Dreher and Sturm 2006), the United Nations (UN) Security Council (Kuziemko and Werker 2006), and most frequently the UN General Assembly. This paper follows the latter line of research though it differs from previous research in a variety of ways. First, following Dreher et al. (2008), it employs disaggregated

\footnotetext{
${ }^{48}$ For example the stated goals of the Swedish International Development Cooperation Agency (SIDA) is to advance economic growth, reduce economic and social inequality, increase economic and political independence, encourage democratic development, protect the environment, and promote gender equality in aid recipient countries. However, sometimes countries admit in their development agency's mission statements their development goals include promoting their own national interests. Two countries that fit this criterion are the United States and Australia.
} 
measures of aid instead of aggregate aid totals to account for heterogeneity in aid types and uses instrument variables to account for the possible endogenous nature of aid. Second, while most of the previous research focuses exclusively on the United States, this paper follows chapter three of this dissertation and considers the 22 members of the Development Assistance Committee (DAC) and each of their influence on "directing" aid recipient voting. ${ }^{49}$ Third, the dataset is constrained to the post-Cold War era because development practices changed after the Cold War (Schraeder et al. 1998) and has shifted to more social development (Moyo 2009), possibly reducing the political nature of aid.

Perhaps the most important contribution of this paper compared to the previous research is that the empirical analysis includes measures of humanitarian aid. Humanitarian aid is becoming an increasingly important category of aid (Cassen 1994 and Addison 2000) yet Dreher et al. (2008) does not include humanitarian aid in their model because they follow the standard explanation advanced by Roodman (2004) and Dollar and Levin (2006) that since humanitarian aid by definition goes to where natural emergencies occur, this aid may not adhere to recipient countries' governance situation. However, there are recent empirical studies that provide evidence that political motivations affect humanitarian aid. Garret and Sobel (2003) find that nearly half of all disaster relief in the United States is motivated by politics rather than by need because presidential and congressional influences affect the rate of disaster declaration and the allocation of FEMA (Federal Emergency Management Agency) disaster expenditures. Building off the work of Garret and Sobel (2003), Sobel and Leeson (2006) apply a public choice analysis of the response by the FEMA to Hurricane Katrina in 2005. They note that disaster relief management is politically manipulated because among other reasons policy makers suffer from

\footnotetext{
${ }^{49}$ The DAC has 24 members. However, the Commission of the European Communities is not a single country with voting powers in the UN and South Korea was not a member of the DAC until January 1, 2010 so they are excluded.
} 
"shortsightedness" bias and their often slow reaction times to emergency situations is the result of type-two errors (errors that result from being over cautious). This affect is not exclusive to the United States. In their study analyzing 344 earthquake disasters between 1975 and 2003, Escaleras et al. (2007) find that public sector corruption is positively related to earthquake deaths.

The paper proceeds as follows. Section two presents a literature review of how development aid influences political support in the UN General Assembly and why using disaggregated aid may be more appropriate than aggregate aid when measuring the political effects of aid. Section three describes the data and introduces the empirical specifications. Section four provides the basic econometric results and provides interpretation. Section five conducts different sensitivity analyses while section six offers concluding remarks.

\subsection{Literature Review}

Researchers investigating the direct ways donor countries solicit political support from recipients through the use of bilateral aid often focus on the change in voting coincidence regarding roll call votes in the UN General Assembly for three reasons. First, all roll call votes are recorded in every session for every voting member creating an availability of data. Second, the UN is an important place for countries to court world opinion and close records of voting behavior is kept by G7 countries (Barnebeck Anderson et al. 2006). ${ }^{50}$ Lastly, the UN is an important player in humanitarian intervention (i.e. the United Nations International Children's Emergency Fund [UNICEF]) and international affairs (i.e. the current debate over the conflict in Libya). Dreher and Sturm (2006) summarize many of the findings and find the empirical evidence is inconclusive and mixed, particularly regarding whether US aid is effective in influencing voting

\footnotetext{
${ }^{50}$ One example is the US State Department which records the voting coincidence rates of member countries on issues they deem important.
} 
behavior. Kato (1969), Kegley and Hook (1991), Sexton and Decker (1992), and Morey and Lai (2006) do not find evidence for aid as an effective tool to influence voting behavior. Bernstein and Alpert (1971), Rai (1972 and 1980), Wittkopf (1973), Lundborg (1998), Wang (1999), Dreher et al. (2008), and chapter 3 of this dissertation find evidence that foreign aid increases voting coincidence between donor and recipient countries.

In each of these studies except for Wittkopf (1973), Lundborg (1998), Dreher et al. (2008), and chapter 3 of this dissertation, the aid donor considered is the United States. ${ }^{51}$ Wittkopf considers 96 aid recipient countries, the 13 members of the DAC at the time, as well as the Soviet Block for the period of 1962 to analyze whether the allocation of donor's aid dollars describes and explains the voting preferences of developing nations. Using pairwise voting patterns, he finds only aid from the US is significantly associated with voting coincidence. Lundborg creates a "gift exchange" model to explain the interaction of the aid given by the Soviet Union and the United States and the political support they obtained. Dreher et al. uses disaggregated aid categories to analyze 143 aid recipient countries and the aid donors of the G7 from 1973 to 2002. They find the US "buys" voting coincidence with general budget support and ODA grants but find no comparable patterns for the other G7 countries. Chapter 3 of this dissertation considers 155 aid recipient countries and 22 DAC countries from 1991 to 2008 and provides evidence Canada, France, Spain, and the United Kingdom exhibit a positive relationship between voting coincidence and development aid distribution.

Each of the earlier studies except for Dreher et al. (2008) employs aggregate aid totals. However, strong reasons exist why using disaggregated aid may be more appropriate. Cassen (1986), Levy (1987), and White (1998) stress aid disaggregation changes the overall

\footnotetext{
${ }^{51}$ Lundborg uses a relative share of support for the US and Soviet Union.
} 
understanding on how aid works in practice. ${ }^{52}$ Different types of aid have singular lag-structures and react differently to the varying conditions in recipient countries, particularly the state of aid co-ordination (Mavrotas and Ouattara 2006). Isenman and Ehrenpreis (2003) explain donors pursue multiple objectives when granting aid causing these specific purposes to be obfuscated in aggregate totals which are better captured by aid disaggregates. Mavrotas and Nunnenkamp (2007) argue that using a total aid figure may result in aggregation bias that may blur empirical results because different aid categories exert different macroeconomic effects and because donor and recipient countries attach different utility to each category of aid. This aggregation bias may explain why growth effects of aid are difficult to detect (Clemens et al. 2004). Dreher et al. (2008) argue different aid categories are more likely to be granted for political purposes than others. These concerns become more important as the composition of aid changes over time and donors focus on different aid categories (Theile et al. 2007).

\subsection{Data and Estimation}

\subsubsection{Descriptions of data and variables}

The paper employs pooled time-series cross-section data sets of DAC countries and 155 aid recipient countries (the exact number of aid recipient countries used in each regression depends on the aid donor considered as well as the model specification) from 1991 to 2007. Data is not available for each variable in every year, creating an unbalanced panel and the number of observations in each regression depends on the choice of explanatory variables. A detailed data description and sources for all variables are provided in Appendix 4A. ${ }^{53}$

\footnotetext{
${ }^{52}$ An example includes Neumayer (2005) who finds the food aid allocation from the European Union, nongovernment organizations, and multilateral aid organizations are sensitive to recipient needs, a different result from previous results on the allocation of aggregate aid.

${ }^{53}$ Specifically, 22 data sets are used, one for each DAC country.
} 
The model used is a variant of the models in the literature and most closely follows the model employed in chapter 3. The basic specification is of the following form:

$$
\mathrm{VC}_{\mathrm{i}, \mathrm{t}}=\beta_{0}+\beta_{1} \text { ODA }_{\mathrm{i}, \mathrm{t}-1}+\beta_{2} \text { Democracy }_{\mathrm{i}, \mathrm{t}-1}+\beta_{3} \text { National Capability }_{\mathrm{i}, \mathrm{t}-1}+\dot{\varepsilon}
$$

where $i$ and $t$ are the country and year indices, respectively. When the system GMM estimator of Arellano and Bond (1991) is used, two lag values of the dependent variable are also included.

The dependent variable (VC) is a measure of voting coincidence. While voting coincidence is measured differently in the literature ${ }^{54}$ this study measures voting coincidence as votes where the donor and recipient country have active agreement in policy positions because donor countries may "bribe recipient governments not only to comply, but also to avoid noncompliance" (Dreher et al. 2008). All roll call votes in the UN General Assembly, including near unanimous and unanimous votes, are included because not all votes are similarly important for the 22 DAC countries considered and determining which votes are "important" is subjective (Kegley and McGowan 1981). Therefore, Wittkopf (1973) states the general approach of using all votes is preferable to focusing on a subjective set of "important" votes. Voting coincidences are based on voting records from the United Nations Bibliographic Information System (UNBISNET), which records all resolutions along with each member's status and voting actions. Voting actions are recorded as 'Yes', 'No', 'Abstentions', and 'Non-Voting'. Voting coincidence is calculated as the ratio of the total number of times two countries' votes match to the number of resolutions with a roll call vote in the same year.

The key independent variables are the disaggregated measures of bilateral aid. Mavrotas and Ouattara (2006) identify different categories of aid. These include technical assistance,

\footnotetext{
${ }^{54}$ Voting coincidence is measured differently in the literature for two reasons. First, abstentions and absences are sometimes discarded (Kegley and Hook 1991), included (Barro and Lee 2005, Dreher et al. 2008, and chapter 3), or weighted as "neutral" (Thacker 1999). The second issue is whether all roll call votes (Wittkopf 1973, Barro and Lee 2005, Dreher et al. 2008, and chapter 3) or certain votes (Wang 1999) should be included.
} 
project aid, program aid, commodity aid (which adds directly to consumption), and emergency (relief) aid. Aid can also be broadly divided between concessional loans (often granted at below market interest rates and at longer periods than average commercial loans) and grants. This study disaggregates aid into loans and grants and project, program, and humanitarian aid ${ }^{55}$ (see Appendix 4A for further details). Program aid is then further divided into budget aid, food aid, and debt relief. ${ }^{56}$ Aid commitments rather than aid disbursements are used for three reasons. First, aid disbursements and commitments are highly correlated and estimation results are unlikely to be affected (Neumayer 2003). Second, commitments are the only type of aid donors control completely (Berthelemy and Tichit 2004). Lastly, the data availability of commitments is greater than disbursements for some of the disaggregated aid categories.

Recipients may view these aid categories differently and attach different utility to each, causing each category to have distinct effects on the recipient countries. Program aid may be more desirable than project aid because recipients have almost complete control over program aid (Roodman 2004), it is disbursed much quicker than project aid, which has a lengthy time from initial disbursement to project completion, and thus is more likely that recipients will be more inclined to return political favors to donors (Dreher et al. 2008). Budget aid may be more valuable relative to food aid (which may be driven by the donor's desire to placate domestic interest groups) and debt relief (which is cumbersome to recipients) (Dreher et al. 2008). Grants may be viewed differently from loans because grants do not require repayment and could be perfect substitutes for a recipient country's domestic revenues (Moyo 2009) whereas loans may require costly future debt payments.

\footnotetext{
${ }^{55}$ Humanitarian aid includes aid for emergency response, reconstruction relief and rehabilitation, and disaster prevention and preparedness.

${ }^{56}$ Unallocated/unspecified aid is excluded since its purpose cannot be accurately identified and administrative costs of donors are excluded because it does not fall into one of the major categories of development aid.
} 
Measurements of democracy and national capability are also included. A measurement of democracy is included because it is robustly associated with UN voting behavior (Dreher and Sturm 2006), democratic countries tend to vote together (Thacker 1999 and Voeten 2000), and UN voting blocks are relatively stable (Holcombe and Sobel 1996). While earlier studies use other measurement of democracy such as the democracy index provided by Freedom House (Barro and Lee 2005 and Dreher and Sturm 2008), Gastil's annual measurement of political rights and civil freedoms (Wang 1999), or the Polity IV measure, these measurements are insufficient because as ordinal indicator variables, cardinal inferences are unclear. To avoid this problem, the dichotomous variable of Cheibub, Gandhi, and Vreeland (2010) is used. A measurement of national capability is included as a measure of "hard" power, or power obtained though economic or military power, because countries that are stronger are more independent and show foreign policy defiance possibly resulting in lower voting coincidence (Wang 1999). ${ }^{57}$

DAC countries are used in the analysis for two reasons. First, even though most of the research analyzing the political purposes of development aid focuses on the United States, other bilateral donors pursue their self-interest in aid allocation (McGillivray 2003). Schraeder et al. (1998) describes how France uses aid to promote French culture while Japan uses aid to further its economic interests. Australia's official development agency, AusAid, admits in their mission statement they grant aid "in line with Australia's national interest." ${ }^{" 58}$ Another example is Portugal since one of its main objectives for development cooperation is to "support the diffusion and use of the Portuguese language., 59

\footnotetext{
${ }^{57}$ Dreher et al. (2008) finds greater national capability significantly reduces voting coincidence with the US but does not have a significant impact on voting coincidence with other G7 countries.

${ }^{58} \mathrm{http}: / / \mathrm{www}$.ausaid.gov.au/

${ }^{59} \mathrm{http}: / / \mathrm{www} . i p a n \cdot m n e . g o v \cdot p t /$
} 
DAC countries are also used because they are the primary donors of ODA and each DAC country is considered to have a major foreign aid program by the Organization for Economic Cooperation and Development (OECD). ${ }^{60}$ Between 1991 and 2008, DAC countries accounted for 73.7 percent of total ODA compared to 2.5 percent for non-DAC countries and 23.5 percent for multilateral aid agencies. In only one year between the years 1991-2008 was the percentage of total bilateral ODA given by DAC countries lower than 71 percent (60.6 percent in 2006). Since 1991, 15 of the 22 DAC countries used have contributed at least one percent of total bilateral ODA, five countries have given at least five percent of total bilateral ODA, and two countries (Japan and the United States) have given at least ten percent of total bilateral ODA.

\subsubsection{Methodology}

Fixed country and time effects are included in all regressions (not shown for reasons of space) as specified by the Hausman test to control for all stable characteristics and partial out common shocks that may not be adequately captured by the other exogenous variables. ${ }^{61}$ The aid variables may suffer from endogeneity problems (Dreher et al 2008) so the system GMM estimator of Arellano and Bond (1991) is employed and "good donor" instruments are used for the aid variables as suggested by Fleck and Kilby (2006a and 2006b). The instruments used are the ODA variables of Denmark, the Netherlands, Norway, and Sweden because their aid is not affected by the UN voting behavior of aid recipients (Stokke 1989, Alesina and Dollar 2000, and Gates and Hoeffler 2004) and because their aid should be correlated with the aid patterns of the other DAC countries since major donors fixate on the same set of 'aid darlings' (Thiele et al. 2007).

\footnotetext{
${ }^{60}$ The other members that are not part of the DAC do not have major foreign aid programs by OECD standards. ${ }^{61}$ Roodman (2006) suggests individual dummies for each year is necessary in GMM estimation as the estimator assumes no correlation across individuals in the idiosyncratic disturbances.
} 
The results of the system GMM estimation are based on the two-step estimator implemented by Roodman (2006) and include the Windmeijer (2005) finite-sample corrected two-step covariance matrix to correct for downward bias in the standard errors, which are robust to heteroskedasticity and arbitrary patterns of autocorrelation within countries. The Hansen $\mathbf{J}$ test, used to determine the validity of the instruments, ${ }^{62}$ and the Arellano-Bond test of second-order autocorrelation, which detects autocorrelation in levels and must be absent in order for the estimator to be consistent, are reported. ${ }^{63}$ Two lags of the dependent variable are included to model dynamics of the model because fixed effects models only estimate short-run effects and the Hansen $\mathbf{J}$ test does not reject the instruments at conventional levels of significance (in most cases) when both lags are included. The number of instruments is also included. The danger of instrument proliferation is a problem in GMM estimation since it will overparameterize the endogenous variables which will fail to expunge their endogenent component and bias coefficient estimates (Roodman 2006). A standard rule of thumb regarding instrument proliferation is that the number of instruments used should be less than the number of groups (in this analysis groups are countries). While the Hansen $\mathrm{J}$ test does not reject the instruments at conventional levels of significance for some of the countries, instrument proliferation is not an issue in the models.

\subsection{Results for the Basic Model}

Table 4.1 reports estimates when aid is disaggregated into project, program, and humanitarian aid (model 1). The results show voting coincidence rises with the degree of democracy in the recipient country for all 22 donor countries considered, often at the 1 or 5 percent statistical

\footnotetext{
${ }^{62}$ The null hypothesis of the Hansen $\mathrm{J}$ test is the same as the Sargan test: the instruments as a group are exogenous thus a higher p-value is preferred.

${ }^{63}$ The null hypothesis of the Arellano-Bond test of second-order autocorrelation is the absence of autocorrelation and is applied to the differenced residuals. A higher p-value is preferred.
} 
significance level, in line with the results of Dreher et al. (2008). Aid recipient countries that are democracies increase their voting coincidence between 1.95 and 4.5 percent. The measurement of national capability is largely insignificant except for the United Kingdom (at the 5 percent level) and Australia (at the 10 percent level). The lack of significance may present evidence that in the post Cold War era pressure from "hard" power sources is less important than in the Cold War era.

The results also show bilateral program, project, and humanitarian aid rarely has an impact on voting coincidence for the DAC countries. The exceptions are program aid for Australia and New Zealand and humanitarian aid for Denmark and the United Kingdom. A one percent increase in Australia's program aid increases voting coincidence by 0.969 percent while a one percent increase in the UK's humanitarian aid increases voting coincidence by 0.065 percent. ${ }^{64}$ Australia's result is somewhat fragile as it does not have a high Sargan test statistic. Due to the limited number of countries New Zealand gives program aid to (14 countries) and Denmark gives humanitarian aid to (46 countries), these results are sensitive to country inclusion. For example for New Zealand, if Timor-Leste, who receives 36.5 percent of New Zealand's program aid, is dropped from the dataset, program aid becomes statistically insignificant. Denmark's top four humanitarian aid recipients include the war torn countries of Afghanistan, Iraq, Somalia, and Sudan. If any of these countries are dropped, then humanitarian aid becomes statistically insignificant.

Table 4.2 shows the results when program aid is further disaggregated into food aid, budget support, and debt relief (model 2). The measurement of democracy is again highly significant while the measurement of national capability is largely insignificant. Budget support

\footnotetext{
${ }^{64}$ Note the aid variables are measured in percent of GDP so it is more precise to say a 1 percent increase in aid variable $\mathrm{X}$ as a percentage of GDP leads to a $\mathrm{Y}$ percent change in voting coincidence. This distinction makes a large difference when considering small disaggregated aid components.
} 
is positive and statistically significant for Australia, Norway, Portugal, and the United States with a one percent increase in budget support increasing voting coincidence between 0.31 percent and 5.76 percent. The coefficient for food aid for Ireland is positive and significant, even when discarding Ethiopia, which receives 75 percent of Ireland's food aid. The negative coefficient for Switzerland for debt relief may be because "from the perspective of recipients, debt relief tends to be cumbersome and subject to various economic and political conditions" (Dreher et al. 2008). Humanitarian aid is significant for Austria, Finland, Portugal, and Sweden though with a negative coefficient, possibly lending evidence to Roodman (2004) and Dollar and Levin's (2006) critique that humanitarian aid may not adhere to recipient countries' governance situation. ${ }^{65}$

However, the disaggregated aid variables are again sensitive to country inclusion. The significance of budget support for New Zealand disappears if Timor-Leste, which receives 42 percent of New Zealand's budget support, is dropped. The statistical significance of food aid for Norway is driven by the inclusion of Zambia, which constitutes 42 percent of Norway's food aid while the significance of food aid for Portugal is driven by the inclusion of Cape Verde. The results for Belgium, France, Greece, Italy, and the Netherlands should be considered with care as the instruments fail to pass the Sargan test.

Table 4.3 disaggregates total aid into loans and grants (model 3). Again the measurement of democracy is statistically significant while national capability is not. Grants may be viewed more favorably by recipients since donors often "attach strings that siphon off resources to favored rich country industries" when they give bilateral loans (Bulow and Rogoff 2005). However, the results are mixed. The coefficient on grants for Belgium is positive and

\footnotetext{
${ }^{65}$ The models were also estimated without humanitarian aid resulting in only two significant changes. First, debt relief for the United States becomes significant at the 10 percent level and a one percent increase in aid increases voting coincidence by 0.08 percent. Second, food aid becomes insignificant for Portugal.
} 
shows a one percent increase in grants increases voting coincidence by 3 percent while the coefficient on loans shows a one percent increase in loans decreases voting coincidence by 18 percent. The coefficient on grants for Spain is negative, though it is sensitive to the inclusion of other variables (see below). Again due to the limited number of countries the UK gives loans to (4 countries), the result is sensitive to country inclusion. The significance of loans for the United Kingdom is sensitive to the inclusion of Ghana, which constitutes 40 percent of all UK's loans.

In general, these results fall broadly in-line with Dreher et al. (2008) who finds little statistical significance for disaggregated bilateral aid for G7 countries once endogeneity is taken into account. In regards to the largest aid donor, the United States, the results support the findings of Dreher et al. (2008) that budget support influences UN voting behavior. However, these results should not be interpreted as saying that countries do not use development aid for political purposes or that there is no relationship between development aid and voting coincidence. Donor countries may view aggregate aid as a more effective way to influence voting coincidence rather than individual aid categories since some of the disaggregated aid category totals are small compared to total aid (for example food aid only comprised 1.4 percent of total aid). This may help explain why when aggregated aid totals are used, of the non-Nordic countries considered, Canada, France, Spain, and the United Kingdom exhibit a positive relationship between voting coincidence and foreign aid distribution (see chapter 3 ).

Another possibility as to why the disaggregated measurements of aid show little statistically significant effects on voting coincidence may be the fungibility of aid, or more precisely that categorical aid substitutes for government funding by being diverted to spending on other sectors or is used to reduced taxes. The development literature shows ample examples of the fungibility of aid. Denger and Sen (1991) show that development aid is sometimes 
siphoned to the military. Pack and Pack (1993) analyze whether aid provided for specific categories is shifted among them and find that the fungibility of aid results in a thwarting of donor intention as recipients shift aid away from its intended purpose. This line of reasoning was why Friedman (1958) and Bauer (1972) both criticized aid because politicians do not always allocate aid efficiently when measured against the goals of aid programs when they have the ability to move aid. This shifting of aid away from donor intention is exactly what Boone (1996) discovers. He notes that aid does not increase investment but instead increases the size of government through an increase in government consumption. This is often not the intention of aid donors as one of the major theoretical reasons in support of aid is that properly designed aid will increase investment and lead to future economic growth, reducing the need for external development aid. Boone's results may help explain why the link between aid and long run economic growth is debatable (see Easterly 2001 and Sachs 2005 for competing views),

While the standard assumption is that aid is fungible because of "malicious" intent by recipients to ignore the preferences of donors, McGillivray and Morrissey (2000) show that aid becomes fungible because donors and recipients have different preferences regarding the allocation of public expenditures. These different preferences become more pronounced because of the lack of donor monitoring of how aid is used. Empirical evidence suggests aid is given irrespective of how well the recipient country is in following the donor's stipulations (Mosley et al. 1995, Collier 1997, and Svensson 2000).

When considering aid's impact on voting patterns the fungibility of aid becomes crucial. If a recipient is successful in moving money between aid categories to their preferred marginal expenditures and a donor attempts to influence a recipient's political behavior though individual aid categories, the individual aid measurements may obscure the statistical results. More 
specifically, if aid recipients are successful in transferring money between aid categories, the total aid may be more important to the recipient than the individual aid categories. It is possible that the individual aid categories may be of greater concern to the donor, especially since it may be easier to tie individual aid projects and categories than it is total aid since aid tying is in general discouraged by the international development community (see chapter 2).

Another possibility for the lack of statistical significance in the variables of interest could be because the results act as a lower bound of political influence because of similar voting coincidences among DAC countries and the possibility of free riding. The high voting coincidence among DAC countries provides incentives for countries to achieve their political goals by free riding off countries that share their same political goals but are willing to bear the burden of the cost of securing this support through the distribution of aid, a cost the free riding country avoids. This issue is explored in chapter 3 of this dissertation through analyzing the raw data of voting coincidences among DAC countries and the use of factor analysis but as this chapter shares the same voting data, the results are the same. The results show that the average voting coincidence among DAC countries is significantly higher than the average voting coincidence rates for DAC versus non-DAC countries and the voting patterns among the DAC countries are similar. Therefore, there is some evidence that free riding is a possibility. 
Table 4.1: Project, Program, and Humanitarian ODA and UN Voting for DAC Countries

\begin{tabular}{|c|c|c|c|c|c|c|c|c|c|c|c|}
\hline Variable & United States & Japan & France & Germany & United Kingdom & Netherlands & Italy & Canada & Spain & Norway & Sweden \\
\hline \multirow[t]{2}{*}{ Voting coincidence (t-1) } & 0.4099 & 0.4168 & 0.3916 & 0.3834 & 0.3674 & 0.3821 & 0.3672 & 0.4492 & 0.3634 & 0.3288 & 0.3455 \\
\hline & $(0.0811) * * *$ & $(0.0643)^{* * *}$ & $(0.0586) * * *$ & $(0.0647)^{* * *}$ & $(0.0596)^{* * *}$ & $(0.0662)^{* * *}$ & $(0.0633)^{* * *}$ & $(0.0535)^{* * *}$ & $(0.0680)^{* * *}$ & $(0.0557)^{* * * *}$ & $(0.0779)^{* * *}$ \\
\hline \multirow[t]{2}{*}{ Voting coincidence $(\mathrm{t}-2)$} & 0.0680 & 0.2498 & 0.2097 & 0.2504 & 0.3849 & 0.1742 & 0.2757 & 0.1443 & 0.2888 & 0.2699 & 0.2091 \\
\hline & $(0.0884)$ & $(0.1080)^{* *}$ & $(0.1076)^{* *}$ & $(0.1190) * *$ & $(0.1066) * * *$ & $(0.0997) *$ & $(0.1220) * *$ & $(0.0907)$ & $(0.1193) * *$ & $(0.1089)^{* * * *}$ & $(0.1150)^{*}$ \\
\hline \multirow[t]{2}{*}{ Project Aid (t-1) } & -0.0895 & -2.4228 & 1.8611 & 0.5992 & 0.9650 & 0.6701 & -6.4467 & 0.8331 & -1.6826 & 0.1117 & 2.2644 \\
\hline & $(0.1413)$ & (1.9474) & 1.6760 & (2.1072) & (1.1884) & (1.1368) & $(6.0551)$ & (4.8462) & (8.8871) & (2.1418) & $(2.3331)$ \\
\hline \multirow[t]{2}{*}{ Humanitarian Aid (t-1) } & -0.0092 & -0.0227 & -0.0095 & -0.1184 & 0.0657 & -0.0385 & -0.1926 & -0.2625 & 0.0635 & 0.0904 & -0.3527 \\
\hline & $(0.0060)$ & $(0.0440)$ & $(0.0516)$ & $(0.1507)$ & $(0.0266) * * *$ & $(0.0330)$ & $(0.1468)$ & $(0.1946)$ & $(0.1229)$ & $(0.2211)$ & $(0.3065)$ \\
\hline \multirow[t]{2}{*}{ Program Aid (t-1) } & 0.1282 & 0.0498 & 0.2097 & -0.1406 & -0.3154 & -1.1988 & 1.8978 & -3.4443 & 1.6108 & 0.7907 & 1.2636 \\
\hline & $(0.1097)$ & (1.8234) & $(0.3266)$ & $(0.6507)$ & $(0.7851)$ & (1.6314) & $(2.0057)$ & (4.5129) & $(2.8349)$ & (3.5722) & (2.5946) \\
\hline \multirow[t]{2}{*}{ Democracy $(\mathrm{t}-1)$} & 2.6949 & 2.2995 & 2.4474 & 2.0363 & 1.9915 & 3.0734 & 2.3048 & 2.6099 & 2.3258 & 2.9608 & 2.8863 \\
\hline & $(0.7813)^{* * * *}$ & $(1.0357)^{* * *}$ & $(0.9633)^{* * *}$ & $(1.1843)^{*}$ & $(0.8461)^{* * * *}$ & $(1.1296)^{* * * *}$ & $(1.0550)^{* * *}$ & $(0.8531)^{* * * *}$ & $(1.1190) * *$ & $(1.0873)^{* * * *}$ & $(1.5223)^{*}$ \\
\hline \multirow[t]{2}{*}{ National Capabilities (t-1) } & 0.0220 & 0.1528 & 0.2137 & 0.1865 & 0.0861 & 0.2088 & 0.1579 & 0.1721 & 0.1353 & 0.1113 & 0.1995 \\
\hline & $(0.0728)$ & $0.2052)$ & $(0.3074)$ & $(0.2267)$ & $(0.1192)^{* *}$ & $(0.2045)$ & $(0.3248)$ & $(0.2417)$ & $(0.2701)$ & $(0.1120)$ & $(0.3293)$ \\
\hline Number of countries & 146 & 146 & 146 & 146 & 146 & 146 & 146 & 146 & 146 & 146 & 146 \\
\hline Number of observations & 2235 & 2233 & 2235 & 2229 & 2233 & 2234 & 2235 & 2235 & 2236 & 2233 & 2235 \\
\hline Arellano-Bond test (p-value) & 0.29 & 0.64 & 0.59 & 0.44 & 0.07 & 0.84 & 0.44 & 0.95 & 0.30 & 0.34 & 0.60 \\
\hline Number of instruments & 90 & 89 & 85 & 90 & 86 & 78 & 90 & 90 & 79 & 78 & 78 \\
\hline Hansen J stat. (p-value) & 0.64 & 0.48 & 0.22 & 0.42 & 0.71 & 0.21 & 0.08 & 0.37 & 0.28 & 0.30 & 0.03 \\
\hline
\end{tabular}

\begin{tabular}{|c|c|c|c|c|c|c|c|c|c|c|c|}
\hline Variable & Denmark & Australia & Belgium & Switzerland & Austria & Finland & Portugal & Ireland & Greece & Luxembourg & New Zealand \\
\hline Voting coincidence (t-1) & $\begin{array}{c}0.3398 \\
(0.0647)^{* * * *}\end{array}$ & $\begin{array}{c}0.3833 \\
(0.0689)^{* * * *}\end{array}$ & $\begin{array}{c}0.3777 \\
(0.0558)^{* * * *}\end{array}$ & $\begin{array}{c}0.2194 \\
(0.1293)^{*}\end{array}$ & $\begin{array}{c}0.3602 \\
(0.0590)^{* * * *}\end{array}$ & $\begin{array}{c}0.3916 \\
(0.0677)^{* * * *}\end{array}$ & $\begin{array}{c}0.3947 \\
(0.0723)^{* * * *}\end{array}$ & $\begin{array}{c}0.3200 \\
(0.0493)^{* * * *}\end{array}$ & $\begin{array}{l}0.0284 \\
(0.0989)\end{array}$ & $\begin{array}{c}0.3563 \\
(0.0533)^{* * * *}\end{array}$ & $\begin{array}{c}0.3616 \\
(0.0581)^{* * *}\end{array}$ \\
\hline Voting coincidence $(\mathrm{t}-2)$ & $\begin{array}{l}0.1034 \\
(0.1291)\end{array}$ & $\begin{array}{c}0.2066 \\
(0.1086)^{*}\end{array}$ & $\begin{array}{c}0.2534 \\
(0.1058)^{* *}\end{array}$ & $\begin{array}{l}0.0123 \\
(0.1295)\end{array}$ & $\begin{array}{c}0.2838 \\
(0.1301)^{* * *}\end{array}$ & $\begin{array}{c}0.2369 \\
(0.1142)^{* *}\end{array}$ & $\begin{array}{c}0.1800 \\
(0.0903)^{* *}\end{array}$ & $\begin{array}{c}0.3486 \\
(0.1266)^{* * *}\end{array}$ & $\begin{array}{l}0.1236 \\
(0.9882)\end{array}$ & $\begin{array}{c}0.2659 \\
(0.0835)^{* * *}\end{array}$ & $\begin{array}{c}0.1832 \\
(0.1106)^{*}\end{array}$ \\
\hline Project Aid (t-1) & $\begin{array}{l}0.2802 \\
(1.3529)\end{array}$ & $\begin{array}{l}-0.0547 \\
(0.7280)\end{array}$ & $\begin{array}{l}2.3109 \\
(2.4171)\end{array}$ & $\begin{array}{l}-8.9071 \\
(6.5033)\end{array}$ & $\begin{array}{l}5.4984 \\
(7.2250)\end{array}$ & $\begin{array}{l}-0.4950 \\
(8.6568)\end{array}$ & $\begin{array}{l}0.4944 \\
(0.5873)\end{array}$ & $\begin{array}{l}12.1475 \\
(9.5526)\end{array}$ & $\begin{array}{l}-21.1299 \\
(14.8321)\end{array}$ & $\begin{array}{l}-4.6813 \\
(8.2055)\end{array}$ & $\begin{array}{l}-2.4291 \\
(3.4802)\end{array}$ \\
\hline Humanitarian Aid (t-1) & $\begin{array}{c}-1.0156 \\
(0.4829)^{* *}\end{array}$ & $\begin{array}{l}0.0782 \\
(0.0745)\end{array}$ & $\begin{array}{l}-0.0248 \\
(0.4240)\end{array}$ & $\begin{array}{l}-0.5939 \\
(0.5830)\end{array}$ & $\begin{array}{l}-4.3162 \\
(4.0641)\end{array}$ & $\begin{array}{l}-0.5558 \\
(0.5391)\end{array}$ & $\begin{array}{l}-2.0697 \\
(2.3430)\end{array}$ & $\begin{array}{l}-0.3166 \\
(0.3421)\end{array}$ & $\begin{array}{l}10.7304 \\
(10.2189)\end{array}$ & $\begin{array}{l}1.1510 \\
(1.9836)\end{array}$ & $\begin{array}{l}0.2528 \\
(1.5973)\end{array}$ \\
\hline Program Aid (t-1) & $\begin{array}{l}-0.8736 \\
(5.3887)\end{array}$ & $\begin{array}{c}0.9686 \\
(0.5173)^{*}\end{array}$ & $\begin{array}{l}0.3796 \\
(0.6174)\end{array}$ & $\begin{array}{l}-17.1667 \\
(11.6809)\end{array}$ & $\begin{array}{l}5.1301 \\
(3.8330)\end{array}$ & $\begin{array}{c}-8.3426 \\
(16.3869)\end{array}$ & $\begin{array}{l}-0.1816 \\
(0.4582)\end{array}$ & $\begin{array}{l}15.6808 \\
(41.1252)\end{array}$ & $\begin{array}{l}-5325.422 \\
(6436.471)\end{array}$ & $\begin{array}{c}-13.017 \\
(14.9629)\end{array}$ & $\begin{array}{c}-33.6481 \\
(6.7532) * * *\end{array}$ \\
\hline Democracy $(\mathrm{t}-1)$ & $\begin{array}{l}4.0122 \\
(1.5208)\end{array}$ & $\begin{array}{c}2.2976 \\
(0.8930)^{* * *}\end{array}$ & $\begin{array}{c}2.1561 \\
(1.0073)^{* *}\end{array}$ & $\begin{array}{c}4.2168 \\
(1.7624)^{* * *}\end{array}$ & $\begin{array}{c}2.1372 \\
(1.1083)^{*}\end{array}$ & $\begin{array}{c}2.4873 \\
(1.0048) * * *\end{array}$ & $\begin{array}{c}2.4396 \\
(0.9974)^{* *}\end{array}$ & $\begin{array}{c}1.9514 \\
(0.9417)^{* *}\end{array}$ & $\begin{array}{c}4.5645 \\
(1.7091)^{* * *}\end{array}$ & $\begin{array}{c}2.0851 \\
(0.8559)^{* *}\end{array}$ & $\begin{array}{c}2.4458 \\
(0.9497)^{* * *}\end{array}$ \\
\hline National Capabilities (t-1) & $\begin{array}{l}0.3002 \\
(0.2196)\end{array}$ & $\begin{array}{c}0.0171 \\
(0.1777)^{*}\end{array}$ & $\begin{array}{l}0.0963 \\
(0.1495)\end{array}$ & $\begin{array}{l}0.0655 \\
(0.2379)\end{array}$ & $\begin{array}{l}0.0336 \\
(0.1766)\end{array}$ & $\begin{array}{l}0.1454 \\
(0.2078)\end{array}$ & $\begin{array}{l}0.1367 \\
(0.1782)\end{array}$ & $\begin{array}{l}0.0698 \\
(0.1543)\end{array}$ & $\begin{array}{l}0.0012 \\
(0.3717)\end{array}$ & $\begin{array}{l}0.0247 \\
(0.1290)\end{array}$ & $\begin{array}{l}0.0707 \\
(0.1849)\end{array}$ \\
\hline Number of countries & 146 & 146 & 146 & 145 & 14 & 146 & 146 & 145 & 146 & 146 & 146 \\
\hline Number of observations & 2233 & 2235 & 2233 & 714 & 2038 & 2235 & 2235 & 2215 & 2235 & 2235 & 2231 \\
\hline Arellano-Bond test (p-value) & 0.87 & 0.55 & 0.39 & 0.85 & 0.48 & 0.57 & 0.87 & 0.18 & 0.63 & 0.22 & 0.71 \\
\hline Number of instruments & 75 & 89 & 87 & 35 & 83 & 89 & 81 & 63 & 55 & 59 & 59 \\
\hline Hansen J stat. (p-value) & 0.77 & 0.06 & 0.54 & 0.57 & 0.41 & 0.35 & 0.71 & 0.59 & 0.02 & 0.30 & 0.40 \\
\hline
\end{tabular}

Robust standard errors in parentheses. $* * *=1 \%, * *=5 \%, *=10 \%$ significance level. 
Table 4.2: Project, Program Disaggregated, and Humanitarian ODA and UN Voting for DAC Countries

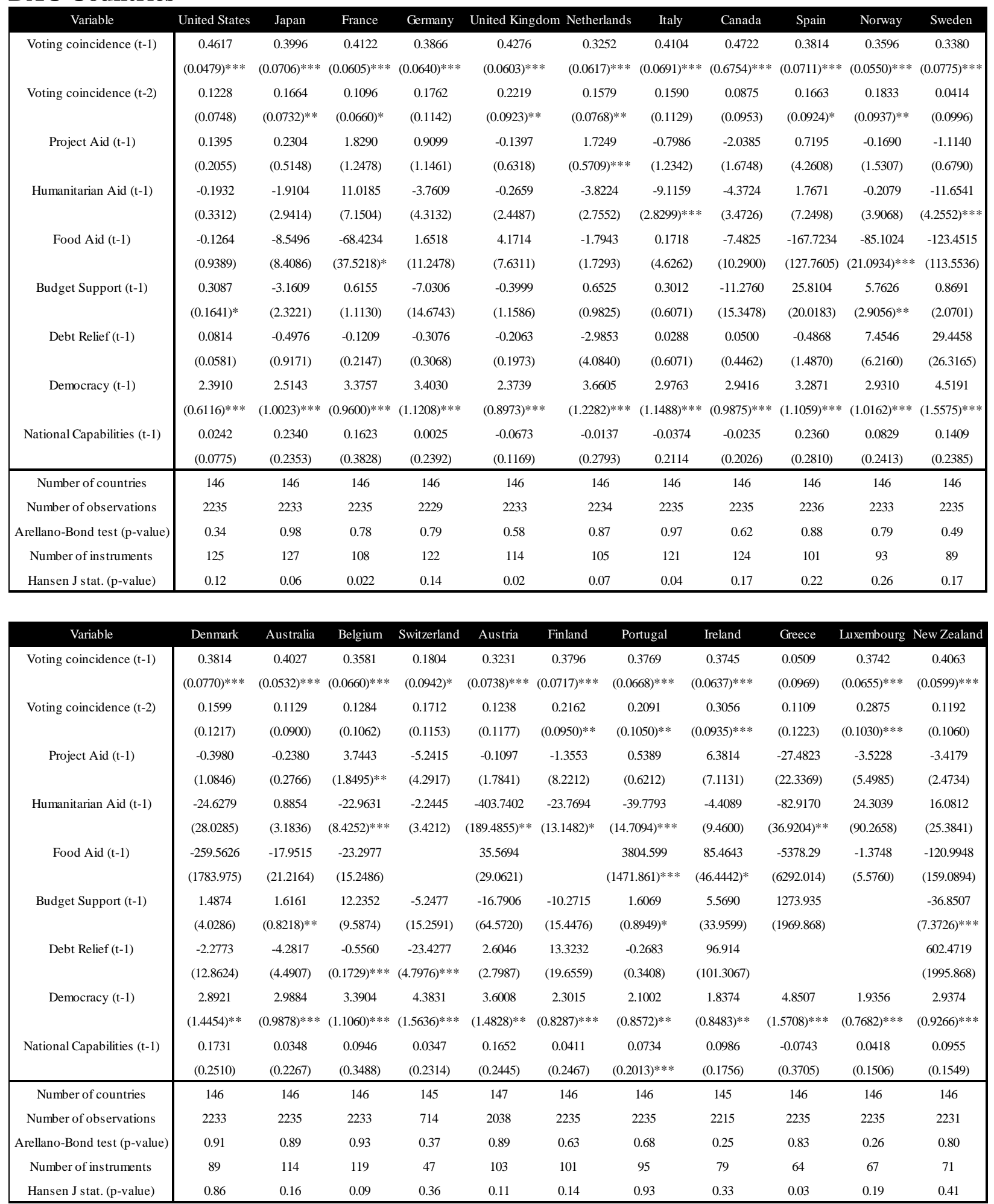

Robust standard errors in parentheses. $* * *=1 \%, * *=5 \%, *=10 \%$ significance level. Please note some coefficients are missing because these variables were dropped in estimation because they had no within-subject variation. 
Table 4.3: Grants, Loans and UN Voting for DAC Countries

\begin{tabular}{|c|c|c|c|c|c|c|c|c|c|c|c|}
\hline Variable & United States & Japan & France & Germany & United Kingdom & Netherlands & Italy & Canada & Spain & Norway & Sweden \\
\hline \multirow[t]{2}{*}{ Voting coincidence (t-1) } & 0.4479 & 0.3519 & 0.3572 & 0.3063 & 0.3193 & 0.3105 & 0.3198 & 0.4109 & 0.3295 & 0.2998 & 0.3251 \\
\hline & $(0.0577)^{* * *}$ & $(0.0649)^{* * *}$ & $(0.0574)^{* * *}$ & $(0.0707)^{* * *}$ & $(0.0655)^{* * *}$ & $(0.0542)^{* * *}$ & $(0.0648)^{* * *}$ & $(0.0567)^{* * *}$ & $(0.0793)^{* * *}$ & $(0.471)^{* * *}$ & $(0.0613)^{* * *}$ \\
\hline \multirow[t]{2}{*}{ Voting coincidence (t-2) } & 0.1149 & 0.2730 & 0.2544 & 0.1902 & 0.2061 & 0.3149 & 0.3103 & 0.1606 & 0.2193 & 0.4786 & 0.2232 \\
\hline & $(0.0795)$ & $(0.0885)^{* * *}$ & $(0.0985)^{* * *}$ & $(0.1098)^{*}$ & $(0.1372)$ & $(0.1491)^{* *}$ & $(0.1134)^{* * *}$ & $(0.1529)$ & $(0.1137)^{*}$ & $(0.1197)^{* * *}$ & $(0.0879)^{* * *}$ \\
\hline \multirow[t]{2}{*}{ Loans (t-1) } & -0.9068 & -0.8054 & 1.1050 & 2.6744 & 119.852 & 31.4731 & -0.2581 & 717.7847 & -12.2644 & 206.9605 & 464.2848 \\
\hline & (1.4024) & $(1.3521)$ & $(1.6155)$ & $(1.8897)$ & $(37.2144)^{* * *}$ & (183.2417) & $(1.1561)$ & (983.98) & (9.1988) & (156.6365) & (425.5558) \\
\hline \multirow[t]{2}{*}{ Grants (t-1) } & 0.0672 & -0.0039 & 0.5940 & -1.4128 & -0.3031 & 0.4082 & 0.5474 & -2.0420 & -1.0239 & -0.0820 & -0.6625 \\
\hline & $(0.1247)$ & (0.6103) & $(0.8472)$ & $(0.9783)$ & $(0.4367)$ & $(0.4913)$ & $(0.9595)$ & (3.1776) & $(0.4897)^{* *}$ & (1.7329) & $(1.3243)$ \\
\hline \multirow[t]{2}{*}{ Democracy (t-1) } & 1.9154 & 2.0022 & 2.8728 & 3.1075 & 3.3042 & 2.2577 & 1.8101 & 3.0094 & 3.2919 & 1.3741 & 2.9037 \\
\hline & $(0.4913)^{* * *}$ & $(1.0260)^{*}$ & $(1.0295)^{* * *}$ & $(1.1806) * * *$ & $(1.1785)^{* * *}$ & $(1.2667)^{*}$ & $(0.9168)^{* *}$ & $(0.9495)^{* * *}$ & $(1.0598)^{* * *}$ & $(1.0599)$ & $(0.9881)^{* * *}$ \\
\hline \multirow[t]{2}{*}{ National Capabilities (t-1) } & 0.0268 & 0.1340 & -0.0210 & 0.0033 & -0.0268 & 0.1184 & -0.0488 & -0.0061 & 0.0566 & -0.0051 & 0.1518 \\
\hline & $(0.0890)$ & $(0.2332)$ & $(0.2107)$ & $(0.1934)$ & $(0.1688)$ & $(0.4913)$ & $(0.1565)$ & $(0.2279)$ & $(0.1745)$ & $(0.1277)$ & $(0.2143)$ \\
\hline Number of countries & 146 & 146 & 146 & 146 & 146 & 146 & 146 & 146 & 146 & 146 & 146 \\
\hline Number of observations & 2235 & 2233 & 2235 & 2229 & 2233 & 2234 & 2235 & 2235 & 2236 & 2233 & 2235 \\
\hline Arellano-Bond test (p-value) & 0.36 & 0.29 & 0.27 & 0.58 & 0.59 & 0.26 & 0.20 & 0.94 & 0.49 & 0.01 & 0.42 \\
\hline Number of instruments & 71 & 71 & 71 & 71 & 58 & 55 & 71 & 66 & 66 & 59 & 54 \\
\hline Hansen J stat. (p-value) & 0.35 & 0.23 & 0.05 & 0.49 & 0.21 & 0.54 & 0.67 & 0.71 & 0.15 & 0.77 & 0.34 \\
\hline
\end{tabular}

\begin{tabular}{|c|c|c|c|c|c|c|c|c|c|c|c|}
\hline Variable & Denmark & Australia & Belgium & Switzerland & Austria & Finland & Portugal & Ireland & Greece & Luxembourg & New Zealand \\
\hline \multirow[t]{2}{*}{ Voting coincidence (t-1) } & 0.3192 & 0.3833 & 0.3076 & 0.1056 & 0.3365 & 0.3572 & 0.3907 & 0.3048 & 0.0022 & 0.2959 & 0.3051 \\
\hline & $(0.0618)^{* * * *}$ & $(0.0561)^{* * *}$ & $(0.0564)^{* * *}$ & $(0.1482)$ & $(0.0625)$ & $(0.0807)^{* * *}$ & $(0.0824)^{* * *}$ & $(0.0525)^{* * *}$ & $(0.0887)$ & $(0.0580) * * *$ & $(0.0646)^{* * * *}$ \\
\hline \multirow[t]{2}{*}{ Voting coincidence $(\mathrm{t}-2)$} & 0.1199 & -0.0010 & 0.2553 & 0.0066 & 0.1611 & 0.1868 & 0.0241 & 0.1728 & 0.0296 & 0.2425 & 0.2191 \\
\hline & $(0.1026)$ & $(0.0459)$ & $(0.0753)^{* * *}$ & (0.1998) & $(0.1383)$ & $(0.1271)$ & (0.1347) & $(0.1443)$ & $(0.0941)$ & $(0.1351)^{*}$ & $(0.1306)^{*}$ \\
\hline \multirow[t]{2}{*}{ Loans (t-1) } & -415.5702 & 797.3124 & -18.5949 & & 8.2756 & -2577.718 & 0.1783 & & & & -4735.006 \\
\hline & (326.8244) & (5535.669) & $(10.1094)^{*}$ & & (25.0857) & (2457.795) & (0.5916) & & & & (5811.463) \\
\hline \multirow[t]{2}{*}{ Grants (t-1) } & -0.4490 & -0.2640 & 3.0696 & -2.8367 & 0.9902 & -6.2809 & -0.9953 & -1.1161 & -3.3048 & 1.7749 & -2.0872 \\
\hline & (1.3258) & $(0.2416)$ & $(1.6399)^{*}$ & (6.9477) & (2.4832) & (8.8670) & (1.3222) & (6.0347) & $(21.6752)$ & (2.9463) & $(2.5320)$ \\
\hline \multirow[t]{2}{*}{ Democracy (t-1) } & 3.4773 & 4.2443 & 2.0536 & 5.5829 & 3.2633 & 2.3979 & 4.1121 & 3.3607 & 4.9692 & 2.8719 & 3.1105 \\
\hline & $(1.2856) * * *$ & $(1.5545)^{* * *}$ & $(0.9758)^{* * *}$ & $(2.7003)^{* *}$ & $(1.0314)^{* * *}$ & $(1.1192)^{* *}$ & $(1.4775)^{* * *}$ & $(1.3651)^{* * *}$ & $(1.8752)^{* * *}$ & $(1.1348)^{* * * *}$ & $(1.3099)^{* *}$ \\
\hline \multirow[t]{2}{*}{ National Capabilities (t-1) } & 0.1877 & 0.0590 & 0.0292 & 0.1565 & 0.0206 & 0.2078 & 0.1230 & 0.1371 & 0.0295 & 0.1210 & 0.1350 \\
\hline & $(0.2141)$ & $(0.2350)$ & $(0.2199)$ & $(0.3154)$ & $(0.1607)$ & $(0.2869)$ & $(0.2991)$ & $(0.2239)$ & $(0.4391)$ & $(0.1662)$ & $(0.2102)$ \\
\hline Number of countries & 146 & 146 & 146 & 145 & 147 & 146 & 146 & 145 & 146 & 146 & 146 \\
\hline Number of observations & 2233 & 2235 & 2233 & 714 & 2038 & 2235 & 2355 & 2215 & 2235 & 2235 & 2231 \\
\hline Arellano-Bond test (p-value) & 0.83 & 0.09 & 0.22 & 0.81 & 0.97 & 0.82 & 0.43 & 0.82 & 0.92 & 0.38 & 0.50 \\
\hline Number of instruments & 49 & 56 & 71 & 23 & 62 & 64 & 69 & 47 & 45 & 47 & 48 \\
\hline Hansen J stat. (p-value) & 0.72 & 0.11 & 0.17 & 0.46 & 0.65 & 0.15 & 0.44 & 0.34 & 0.01 & 0.47 & 0.49 \\
\hline
\end{tabular}

Robust standard errors in parentheses. $* * *=1 \%, * *=5 \%, *=10 \%$ significance level. Please note some coefficients are missing because these variables were dropped in estimation because they had no within-subject variation. 


\subsection{Sensitivity Analyses}

Table 4.4 tests the robustness of the results to the inclusion of three categories of additional variables suggested in the literature as possible determinants of voting coincidence. The first category measures economic power as measured by GDP per capita and real GDP growth. This category is included because economically stronger countries may show more foreign policy defiance (Wang 1999), which may result in lower voting coincidence, or may result in higher voting coincidence because countries with similar wealth levels may be converging towards similar preferences. Its influence on voting patterns is thus a priori ambiguous.

The second category considers international trade patterns and is measured by imports from the recipient country to donor country and exports from the donor country to the recipient country. Trade is a potential measure of foreign influence (Stone 2004) and creates interdependence among countries which may create similar preferences among trading partners and greater cooperation (Oneal and Russett 1999). This increased dependency may increase a country's responsiveness to external pressure which may lead to voting compliance with the trading partner, particularly if the trading partner is large (Keohane 1967), or if the increased trade dependence also increases recipient fears of losing access to the markets of the donor. However strong economic ties with developed countries may create feelings of exploitation and could give rise to voting against these countries (Kim and Russett 1996). Again while trade is important, its impact on voting patterns is thus a priori ambiguous.

The last category measures dependence on foreign support and is measured by external debt. Politically and economically stronger countries with easy access to capital may be less likely to accept bribes and may be less likely to vote with the DAC countries compared to countries who are more constrained in their access to private capital and may need to rely more 
on public support such as development aid (Dreher and Sturm 2006 and Dreher et al. 2008). However, dependence may be higher in times of political instability or crises, making it more difficult to access private capital because less economically secure countries may need assistance from economically stronger countries (Dreher and Sturm 2006). Thus like the trade measure, the measure of dependence on foreign support may be important but its impact on voting patterns is a priori ambiguous. ${ }^{66}$

For reasons of space the coefficients of the variables of interest, along with their standard errors, are included but the covariates are not. The regressions are estimated with two lags of the dependent variable, the democracy and national capability measurements, as well as country and time fixed effects. Also, only the countries with significant results for the aid measures in the basic specification are included. Therefore, the results for France, Germany, Greece, Italy, Japan, Luxembourg, and the Netherlands are not shown since none of their disaggregated aid variables were statistically significant (or failed the Sargan test) when the possible endogeneity of aid is taken into account (their initial results do not change so their absence is only for reason of space).

\footnotetext{
${ }^{66}$ Other variables, such as distance and colonial relationship may also influence voting coincidence. However, during the time sample analyzed, there is no within-subject variation for the countries considered so they are captured in the fixed effects which controls for all stable characteristics of the countries.
} 
Table 4.4: Bilateral Aid and UN Voting, Tests for Robustness

\begin{tabular}{|c|c|c|c|c|c|c|c|c|c|c|c|}
\hline & \multicolumn{5}{|c|}{ Australia } & \multicolumn{5}{|c|}{ Austria } \\
\hline & & GDP per capita & GDP growth & Exports & Imports & External Debt & GDP per capita & GDP growth & Exports & Imports & External Debt \\
\hline \multirow[t]{2}{*}{ (1) } & \multirow[t]{2}{*}{ Project Aid (t-1) } & $0.0595)$ & -0.0412 & 0.3025 & 0.3109 & 0.1549 & 6.8646 & 6.7438 & -6.7488 & -7.8845 & -0.9169 \\
\hline & & $(0.7722)$ & $(0.7480)$ & $(0.9487)$ & $(0.9347)$ & (1.0507) & (7.5439) & (7.5745) & (21.9912) & (21.4825) & $(6.9821)$ \\
\hline \multirow{2}{*}{\multicolumn{2}{|c|}{ Humanitarian Aid (t-1) }} & 0.0814 & -0.0386 & 0.0739 & 0.0739 & 0.0170 & -4.3548 & -3.7512 & -3.2410 & -2.9021 & -1.2138 \\
\hline & & $(0.0756)$ & $(0.0679)$ & $(0.0703)$ & $(0.0711)$ & $(0.05401)$ & $(4.0724)$ & (4.0104) & (3.6041) & (3.5894) & (1.9853) \\
\hline \multirow{2}{*}{\multicolumn{2}{|c|}{ Program Aid (t-1) }} & 0.9476 & 0.9467 & 1.3675 & 1.3074 & 0.6145 & 5.3069 & 4.8887 & 4.1583 & 3.6506 & 1.3794 \\
\hline & & $(0.5277)^{*}$ & $(0.6205)$ & $(0.4347)^{* * *}$ & $(0.4474)^{* * *}$ & $(0.7677)$ & (3.8479) & $(3.7670)$ & (3.3081) & (3.4666) & (2.6715) \\
\hline \multirow[t]{2}{*}{ (2) } & \multirow[t]{2}{*}{ Project Aid (t-1) } & -0.2216 & -0.2407 & -0.1021 & -0.0879 & -0.0467 & 0.2153 & 0.1535 & 2.2317 & 1.7719 & -1.1230 \\
\hline & & $(0.2941)$ & $(0.2776)$ & $(0.3623)$ & $(0.3584)$ & $(0.3353)$ & $(1.7668)$ & (1.9045) & (4.4879) & $(4.4160)$ & (7.3766) \\
\hline \multirow{2}{*}{\multicolumn{2}{|c|}{ Humanitarian Aid (t-1) }} & 1.4490 & 0.0738 & 1.0052 & 1.3321 & 2.0895 & -386.6687 & -370.1181 & -367.3368 & -370.8104 & -210.1808 \\
\hline & & $(3.3714)$ & (3.0573) & $(3.9820)$ & $(3.7953)$ & (3.3094) & $(186.4247)^{* *}$ & $(177.4661)^{* * *}$ & $(164.0145)^{* * *}$ & $(169.3619)^{* * *}$ & (194.184) \\
\hline \multirow{2}{*}{\multicolumn{2}{|c|}{ Food Aid (t-1) }} & -12.2326 & -19.2123 & -33.6710 & -33.3828 & -9.4097 & 34.8606 & 34.7372 & 26.0322 & 25.9392 & 22.9320 \\
\hline & & (20.1878) & (22.0123) & $(31.0961)$ & (30.6929) & (21.8904) & (28.4921) & (28.1072) & (26.3206) & (26.1840) & $(52.7824)$ \\
\hline \multirow{2}{*}{\multicolumn{2}{|c|}{ Budget Support (t-1) }} & 1.5197 & 1.8576 & 2.0427 & 1.8727 & 1.1843 & -17.5632 & -15.5472 & -20.2645 & -19.6649 & 2.5098 \\
\hline & & $(0.8113)^{*}$ & $(0.8666)^{* *}$ & $(0.9752)^{* *}$ & $(0.9019)^{* *}$ & $(0.9226)$ & (64.7953) & (67.5144) & $(62.8287)$ & $(64.1069)$ & $(273.6015)$ \\
\hline \multirow{2}{*}{\multicolumn{2}{|c|}{ Debt Relief (t-1) }} & -3.9645 & -5.1501 & -3.8899 & -3.5599 & -2.2795 & 2.9344 & 2.3031 & 3.4072 & 2.7726 & 1.1521 \\
\hline & & (4.9229) & (4.4494) & (3.2277) & $(3.2102)$ & (3.4379) & (2.7986) & $(2.5928)$ & (2.6619) & (2.4803) & $(25.7209)$ \\
\hline \multirow[t]{4}{*}{ (3) } & Loans (t-1) & 478.946 & -29.4043 & -8784.499 & -6468.627 & -698.1866 & 6.8104 & 7.489 & 74.2633 & 67.9005 & -9.2756 \\
\hline & & $(6807.902)$ & $(6652.61)$ & $(11030.14)$ & (9138.96) & (4487.88) & $(24.8616)$ & $(24.2826)$ & (108.1154) & (107.5469) & $(22.7454)$ \\
\hline & \multirow[t]{2}{*}{ Grants (t-1) } & -0.2416 & -0.3012 & 0.2769 & 0.3077 & 0.2040 & 1.5289 & 1.4728 & 4.1878 & 3.4896 & 1.1372 \\
\hline & & $(0.2185)$ & $(0.2315)$ & $(0.7121)$ & $(0.7433)$ & $(0.6021)$ & (2.5622) & (2.6146) & (8.7881) & (8.7563) & (2.8488) \\
\hline
\end{tabular}

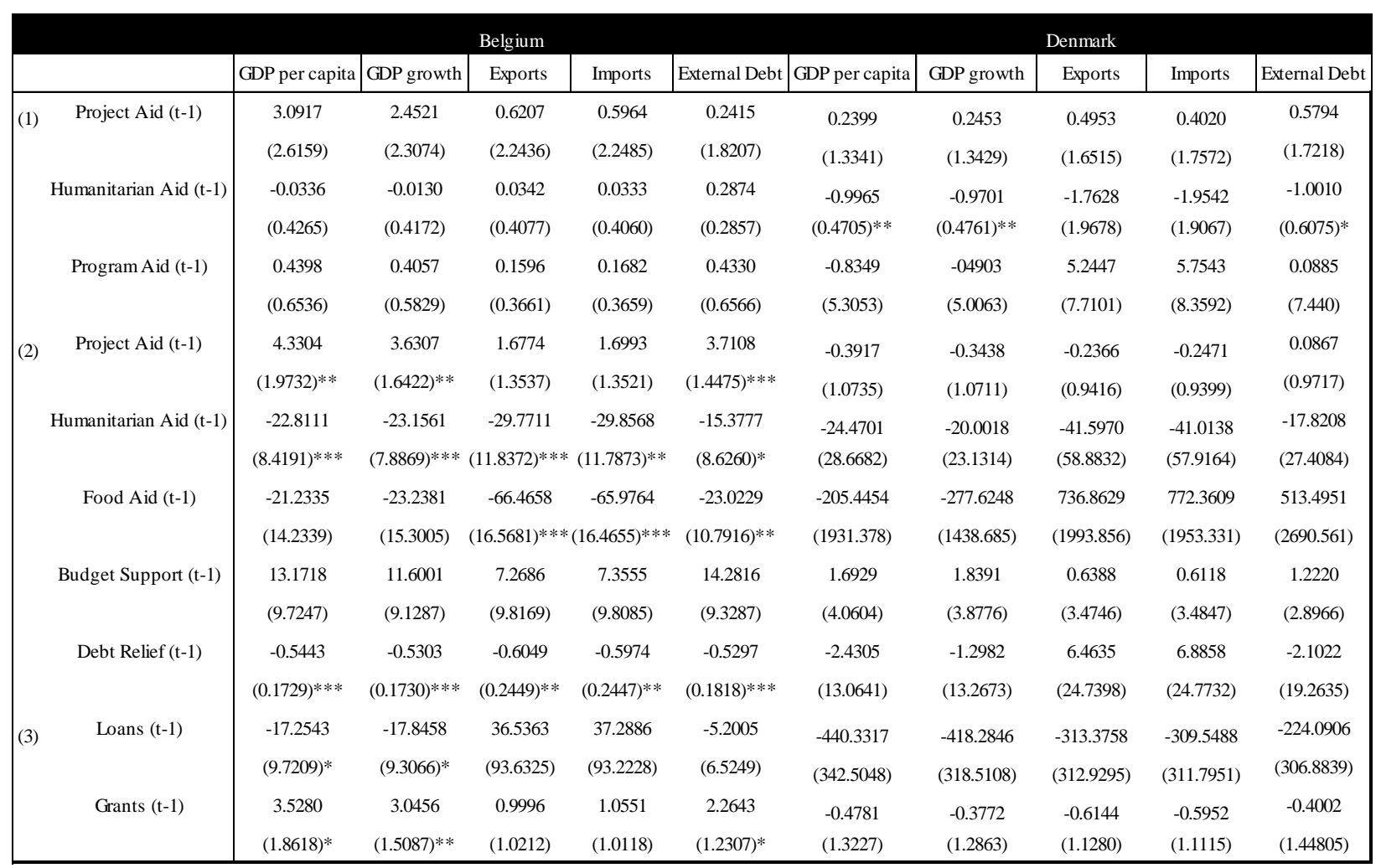

Robust standard errors in parentheses. ${ }^{* * *}=1 \%, * *=5 \%, *=10 \%$ significance level. 
Table 4.4 Continued: Bilateral Aid and UN Voting, Tests for Robustness



\begin{tabular}{|c|c|c|c|c|c|c|c|c|c|c|c|}
\hline & & \multicolumn{5}{|c|}{ New Zealand } & \multicolumn{5}{|c|}{ Norway } \\
\hline & & GDP per capita & GDP growth & Exports & Imports & External Debt & GDP per capita & GDP growth & Exports & Imports & External Debt \\
\hline \multirow{2}{*}{ (1) } & Project Aid (t-1) & -2.4302 & -2.5573 & -0.4981 & -0.9199 & -4.7128 & 0.0370 & 0.2901 & 1.7222 & 1.7533 & 0.1026 \\
\hline & & (3.5112) & (3.3807) & (3.0174) & $(3.8588)$ & (4.8666) & $(2.1520)$ & (2.1172) & (3.2303) & (3.1486) & $(2.2141)$ \\
\hline & Humanitarian Aid (t-1) & 0.3935 & -0.1002 & -0.4712 & 0.2182 & -1.4246 & 0.0902 & 0.0940 & -0.0327 & -0.0225 & -0.2481 \\
\hline & & (1.6946) & $(1.2203)$ & $(1.1792)$ & $(1.5399)$ & (1.7569) & $(0.2255)$ & $(0.2264)$ & $(0.1981)$ & (0.1995) & $(0.3175)$ \\
\hline & Program Aid (t-1) & -32.2974 & -34.1785 & & -233.061 & -164.022 & 0.5829 & 1.0655 & 6.9256 & 7.0097 & 1.8778 \\
\hline & & $(6.2206)^{* * *}$ & $(6.9000)^{* * *}$ & & (500.6308) & (147.7125) & (3.5746) & (3.7559) & $(4.1775)^{*}$ & $(4.1789)^{*}$ & (2.7538) \\
\hline \multirow[t]{2}{*}{ (2) } & Project Aid (t-1) & -3.6321 & -3.5182 & -1.0798 & -2.3893 & -3.2470 & -0.2555 & -0.0970 & 0.0897 & 0.0831 & 0.4652 \\
\hline & & (2.5551) & (2.3625) & $(2.2298)$ & $(3.2669)$ & $(4.0645)$ & $(1.5608)$ & (1.4798) & (2.4099) & (2.4207) & (1.3138) \\
\hline & Humanitarian Aid (t-1) & 20.6556 & 17.7752 & -109.2726 & -46.1749 & -75.2842 & -0.1987 & -0.0622 & 0.1107 & 0.0745 & -5.9521 \\
\hline & & (26.9603) & $(24.0132)$ & (102.9366) & $(85.5483)$ & (117.2312) & (4.0396) & (4.0219) & $(4.2249)$ & (4.1967) & $(3.4968)^{*}$ \\
\hline & Food Aid (t-1) & -115.4169 & -100.6628 & -469.8533 & -250.5413 & -279.6904 & -87.8625 & -91.2471 & 1419.022 & 1426.302 & -79.4405 \\
\hline & & (165.6114) & (134.202) & (378.5115) & $(285.7561)$ & (340.9376) & $(22.0717)^{* * *}$ & $(22.8011)^{* * *}$ & (1291.791) & (1293.876) & $(20.6311)^{* * *}$ \\
\hline & Budget Support (t-1) & -37.1782 & -38.6880 & & & & 5.7619 & 5.7059 & 6.4165 & 6.4798 & 4.8658 \\
\hline & & $(7.4300)^{* * *}$ & $(7.4165)^{* * *}$ & & & & $(2.9165)^{* *}$ & $(2.9355)^{* *}$ & $(3.2744)^{* *}$ & $(3.3070)^{* *}$ & $(2.4896)^{* *}$ \\
\hline & Debt Relief (t-1) & 658.0157 & 522.9215 & -141.6708 & -782.999 & -943.258 & 7.4405 & 7.1801 & 5.4349 & 5.2402 & 6.2458 \\
\hline & & (1994.872) & (1867.354) & (3175.19) & (2790.757) & $(3501.471)$ & $(6.4542)$ & $(6.1433)$ & (7.8162) & (7.7912) & (4.5996) \\
\hline \multirow[t]{4}{*}{ (3) } & Loans $(\mathrm{t}-1)$ & -4677.35 & -4083.681 & -1151.595 & -1817.885 & -2394.279 & 207.896 & 203.1386 & 648.315 & 666.0488 & 175.8578 \\
\hline & & $(5899.201)$ & $(5405.285)$ & (1769.308) & $(2436.32)$ & (3932.261) & (156.5395) & (153.3678) & (484.9479) & (488.4113) & (158.5475) \\
\hline & Grants (t-1) & -1.9286 & -1.9217 & -1.6849 & -0.9827 & -1.8941 & -0.1850 & 0.0219 & -0.6677 & -0.7701 & -0.0656 \\
\hline & & (2.5334) & (2.5946) & (2.1331) & $(2.4610)$ & $(3.7550)$ & (1.7375) & (1.6247) & $(2.1356)$ & (2.1298) & $(1.4571)$ \\
\hline
\end{tabular}

Robust standard errors in parentheses. $* * *=1 \%, * *=5 \%, *=10 \%$ significance level. Please note some coefficients are missing because these variables were dropped in estimation because they had no within-subject variation. 
Table 4.4 Continued: Bilateral Aid and UN Voting, Tests for Robustness

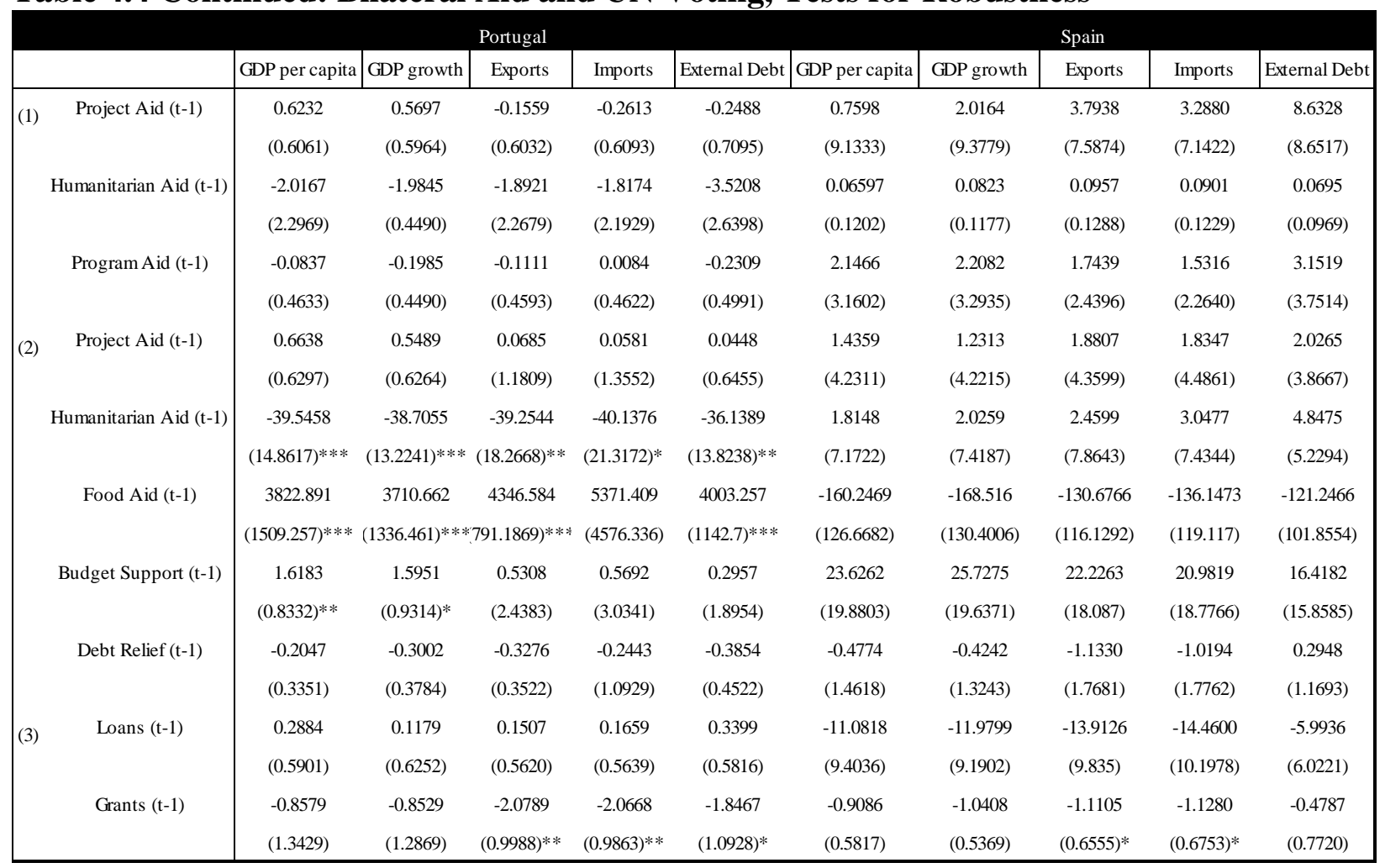

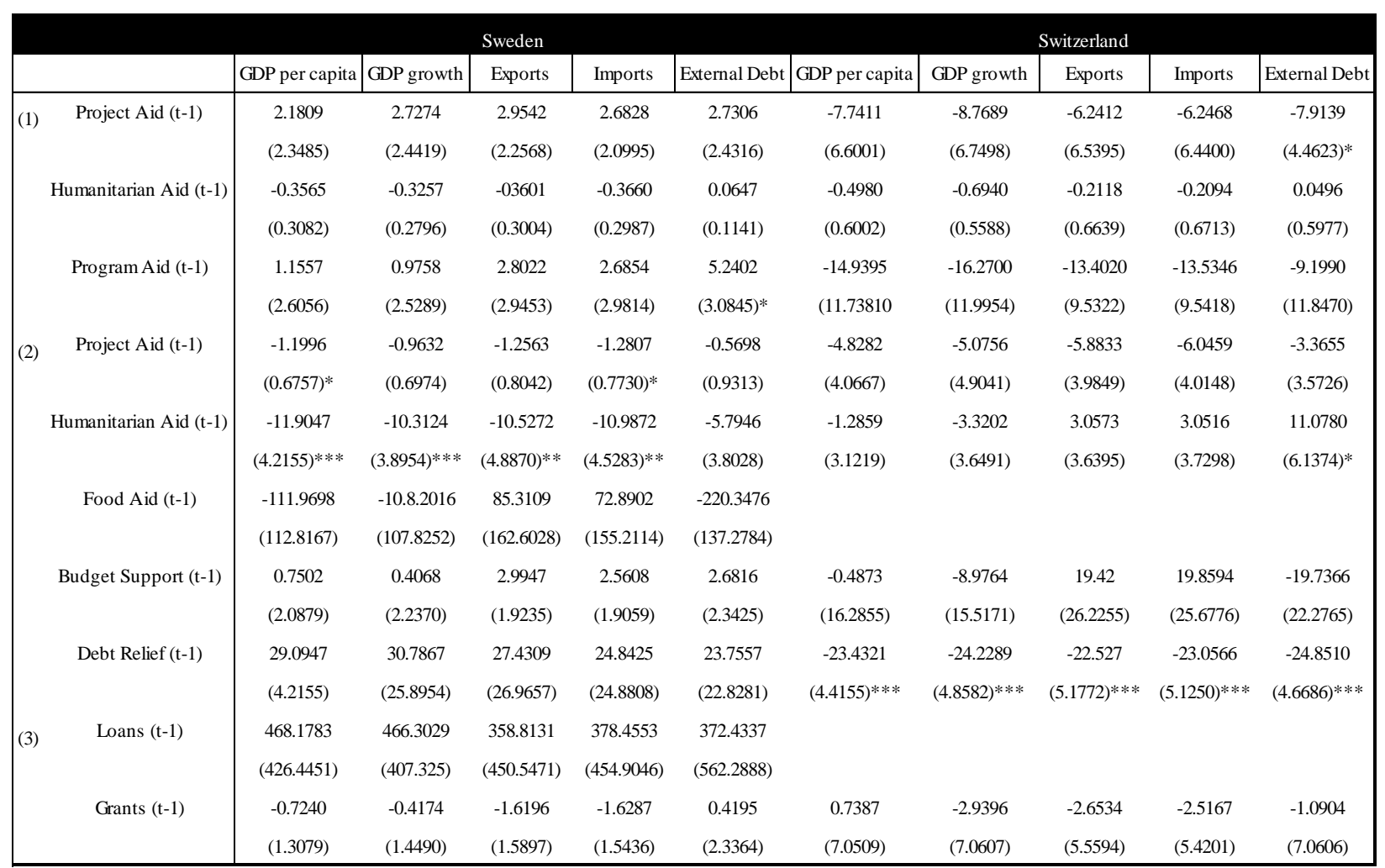

Robust standard errors in parentheses. $* * *=1 \%, * *=5 \%, *=10 \%$ significance level. Please note some coefficients are missing because these variables were dropped in estimation because they had no within-subject variation. 
Table 4.4 Continued: Bilateral Aid and UN Voting, Tests for Robustness

\begin{tabular}{|c|c|c|c|c|c|c|c|c|c|c|c|}
\hline & \multicolumn{5}{|c|}{ United Kingdom } & \multicolumn{5}{|c|}{ United States } \\
\hline & & GDP per capita & GDP growth & Exports & Imports & External Debt & GDP per capita & GDP growth & Exports & Imports & External Debt \\
\hline \multirow[t]{6}{*}{ (1) } & Project Aid (t-1) & 1.2427 & 1.0575 & -0.6079 & -0.6121 & 0.2553 & 0.0136 & -0.1290 & -0.1649 & -0.1080 & 1.5126 \\
\hline & & $(1.2951)$ & $(1.1261)$ & $(1.043)$ & $(1.0076)$ & $(0.2382)$ & $(0.1428)$ & $(0.1579)$ & $(0.2201)$ & $(0.2384)$ & (1.4412) \\
\hline & Humanitarian Aid (t-1) & 0.0705 & 0.0688 & 0.0945 & 0.0945 & -0.0023 & -0.0078 & -0.0116 & -0.0058 & -0.0076 & 0.0110 \\
\hline & & $(0.0245)^{* * *}$ & $(0.0339)^{* *}$ & $(0.0311) * * *$ & $(0.0310) * * *$ & $(0.0042)$ & $(0.0051)$ & $(0.0072)$ & $(0.0062)$ & $(0.0059)$ & $(0.0882)$ \\
\hline & Program Aid (t-1) & -0.2414 & -0.3000 & 0.2374 & 0.2377 & 0.2379 & 0.2032 & 0.1360 & 0.1619 & 0.2424 & -0.3592 \\
\hline & & $(0.7908)$ & $(0.7210)$ & $(0.6305)$ & $(0.6322)$ & $(0.2001)$ & $(0.1294)$ & $(0.1171)$ & $(0.1370)$ & $(0.1764)$ & $(0.8508)$ \\
\hline \multirow[t]{6}{*}{ (2) } & Project Aid (t-1) & 1.6872 & -0.1697 & -0.1176 & -0.1253 & 0.0242 & 0.2258 & 0.1742 & 0.1575 & 0.1692 & 0.2200 \\
\hline & & $(0.5656)^{* * *}$ & $(0.6653)$ & $(0.5420)$ & $(0.5367)$ & $(0.7318)$ & $(0.2178)$ & $(0.1996)$ & $(0.5199)$ & $(0.2098)$ & $(0.2306)$ \\
\hline & \multirow[t]{2}{*}{ Humanitarian Aid (t-1) } & -3.8769 & -0.4115 & 0.9077 & 0.9074 & -0.2884 & -0.1615 & -0.2602 & -0.1926 & -0.1884 & 0.1043 \\
\hline & & (2.7384) & $(2.5241)$ & (1.9837) & (1.9653) & (3.9157) & $(0.2937)$ & (0.3294) & $(0.3056)$ & $(0.2887)$ & $(0.3002)$ \\
\hline & \multirow[t]{2}{*}{ Food Aid (t-1) } & -1.8027 & 5.1001 & -4.1448 & -4.0760 & 1.6265 & 0.1877 & -0.2619 & -0.8967 & -0.8659 & -0.2023 \\
\hline & & (1.7159) & $(8.2051)$ & (5.0066) & (5.0073) & (6.8899) & $(0.8326)$ & $(0.9732)$ & $(1.9701)$ & $(0.7975)$ & $(0.9133)$ \\
\hline \multirow{2}{*}{\multicolumn{2}{|c|}{ Budget Support (t-1) }} & 0.6586 & -0.4283 & -0.3481 & -0.3325 & -0.4822 & 0.3486 & 0.3317 & 0.3019 & 0.3135 & 0.3769 \\
\hline & & $(0.9851)$ & (1.1464) & (0.9776) & $(0.9729)$ & $(1.2122)$ & $(0.1804)^{* *}$ & $(0.1592)^{* * *}$ & $(0.3854)$ & $(0.1657)^{*}$ & (1.0814) \\
\hline \multirow{2}{*}{\multicolumn{2}{|c|}{ Debt Relief (t-1) }} & -3.1449 & -0.2315 & -0.1333 & -0.1434 & -0.0826 & 0.1082 & 0.0872 & 0.06737 & 0.0619 & 0.0932 \\
\hline & & (4.1415) & $(0.2084)$ & $(0.1293)$ & $(0.1234)$ & $(0.1973)$ & $(0.0571)^{*}$ & $(0.0530)^{*}$ & $(0.0908)$ & $(0.0469)$ & $(0.0471) * *$ \\
\hline \multirow{4}{*}{ (3) } & Loans (t-1) & 123.4443 & 115.0986 & 93.7150 & 93.9607 & 115.0131 & -0.3739 & -0.8766 & -0.0569 & -0.1588 & -0.1696 \\
\hline & & $(42.7191)^{* * * *}$ & $(0.0447) * * *$ & $(22.9733) * * *$ & $(23.1458) * * *$ & $(36.9874)^{* * *}$ & (1.2965) & (1.4813) & $(0.8384)$ & $(0.8334)$ & (1.2191) \\
\hline & Grants (t-1) & -0.1829 & -0.3309 & -0.3006 & -0.3101 & 0.0315 & 0.1641 & 0.0704 & 0.0461 & 0.0438 & 0.0094 \\
\hline & & $(0.4097)$ & $(0.4341)$ & $(0.4456)$ & (0.4598) & (0.3858) & (0.1304) & $(0.1313)$ & $(0.1252)$ & $(0.1235)$ & $(0.1658)$ \\
\hline
\end{tabular}

Robust standard errors in parentheses. $* * *=1 \%, * *=5 \%, *=10 \%$ significance level.

Including the economic power variables do not significantly change the basic results.

When the regressions are estimated with GDP per capita included only one coefficient changes significance. In model 3, the coefficient of grants for Spain turns insignificant. However, some variables change significance levels. In model 2, budget support for the United States and Portugal increases in statistical significance from the 10 to 5 percent level. When GDP growth is included, only two coefficients change. In model 2, debt relief for the US turns statistically significant with a one percent increase in debt relief increasing voting coincidence by 0.09 percent. In model 3, the coefficient of grants for Spain again turns insignificant. Again, some variables change significance levels. In model 1, humanitarian aid for the United Kingdom decreases in statistical significance from the 1 to 5 percent level. In model 2, budget support for the United States and humanitarian aid increases in statistical significance from the 10 to 5 
percent level while humanitarian aid for Austria increases in statistical significance from the 5 to 1 percent level.

Accounting for international trade patterns affects the basic results in a much greater way than the insertion of the economic power variables. When estimated with exports, eight coefficients change significance. In model 1, humanitarian aid for Denmark turns insignificant while program aid for Norway turns significant, though only at the 10 percent level. A one percent increase in Norway's program aid increases voting coincidence by 6.93 percent. In model 2, budget support for the United States and Portugal, food aid for Norway, and humanitarian aid for Finland turn insignificant. In model 3, loans and grants for Belgium turn insignificant. Only one variable of interest changes significance level. In model 2 humanitarian aid for Portugal decreases significance from the 1 to 5 percent level.

When imports are included in the estimation, seven coefficients change significance. In model 1, humanitarian aid for Denmark turns insignificant while program aid for Norway becomes significant, again at the 10 percent level. A one percent increase in Norway's program aid increases voting coincidence by 7 percent. In model 2, food aid for Norway, humanitarian aid for Finland, and food and budget aid for Portugal turns insignificant. In model 3, loans and grants for Belgium turn insignificant. Some variables also change significance levels. In model 2, humanitarian aid for Sweden decreases significance from the 1 to 5 percent level and humanitarian aid for Portugal decreases significance from the 1 to 10 percent level.

External debt is the strongest additional variable included. It is statistically significant at the 5 or 1 percent level in most of the countries in all three of the models. Its inclusion also significantly changes the variables of interest. In model 1, humanitarian aid for the United Kingdom becomes insignificant while it becomes significant for the Netherlands at the 5 percent 
level. Program aid for Sweden becomes significant with a 1 percent rise in Swedish program aid increasing voting coincidence by 5.24 percent while project aid for Switzerland turns significant, though only at the 10 percent level. In model 2, humanitarian aid for Austria, Finland, Sweden, budget support for Australia, Portugal, and the United States, and food aid for Ireland all become insignificant. Debt relief for the United States becomes significant at the 5 percent level with a similar coefficient value in earlier specifications and humanitarian aid becomes significant at the 10 percent level. In model 3, loans for Belgium and grants for Spain turn insignificant.

\subsection{Conclusion}

This paper broadens the research on the political influence of aid donors, specifically if donors use development aid to influence the voting behavior of aid recipient countries in the UN General Assembly, in four ways. First, it considers the heterogeneity of development aid by employing disaggregated aid measures because donors pursue multiple objectives and because different aid categories exert different macroeconomic effects since donor and recipient countries attach different utility to each category. Second, unlike most of the previous literature, this paper empirically analyzes all 22 DAC countries instead of just the United States. Third, the paper focuses on the post-Cold War time frame because development aid practices changed after the Cold War towards more social development, possibly reducing the political nature of aid. Lastly, it includes humanitarian aid in the empirical specification because of its increasing importance and because there is evidence in previous literature that humanitarian aid is motivated by political concerns.

Four main highlights can be taken from the results. First, not including humanitarian aid may result in the loss of important information, even if it is theoretically unclear whether humanitarian aid may or may not adhere to recipient countries' governance situation, since it is 
the most significant aid variable in the results and its inclusion does not change the results of the other variables compared to when it is not included. Second, some of the results are sensitive to recipient country inclusion, particularly when donor countries are selective in the number of countries to who they give aid, and many of the results are sensitive to the inclusion of additional variables. This is especially true when international trade patterns and external debt are considered. Third, except for budget support, the results do not show a strong statistical relationship between disaggregated aid categories of the United States, the largest aid donor, and increased voting coincidence. Finally, these results provide some evidence that in the post Cold War era disaggregated aid measures do not show a robust influence on voting coincidence for most of the DAC countries. These results largely follow those of Kato (1969), Kegley and Hook (1991), Sexton and Decker (1992), and Morey and Lai (2006) who find development aid has no impact on inducing recipient countries to vote more in-line with the donor country. ${ }^{67}$

While it is naïve to conclude from the results that development aid is no longer being used for political purposes, several possibilities exist to explain the results. First, it is possible that as the geopolitical atmosphere moves further away from the Cold War, the major aid donors have less of an imperative to use development aid to further international objectives, at least those concerned with UN voting. ${ }^{68}$ Second, aid may be evolving towards social development as it primary objective rather than political influence. The push to reach the Millennium Development Goals is a good example. Third, donors may simply view aggregate aid as a more effect way to influence voting coincidence than individual aid categories because of the fungibility of aid. Fourth, the results could act as a lower bound of political influence due to the possibility of countries free riding off other countries due to the high correlation of voting

\footnotetext{
${ }^{67}$ It is interesting to note this result holds for countries that tie lots of aid and countries that tie little aid.

68 The same cannot be said for China. Please see Moyo (2009) for a more detailed explanation.
} 
coincidence among the DAC countries. Lastly, as other international organizations become more important (i.e. the World Trade Organization), donors may seek to use their development aid for political capital in other international organizations other than the UN General Assembly.

The results also provide some research extensions. While aid is considered fungible and may explain why individual aid categories have little statistical influence on voting patterns, are different categories of aid more fungible than others. For example, the standard reasoning for why grants are more effective than loans as development aid is that recipient countries do not have to pay back grants and are thus not crippled with future debt payments which could hurt long run economic growth. However, if grants are more fungible than loans precisely because loans require repayment whereas grants may allow recipients to ignore donor intention and shift grants away from their intended purpose and towards their preferred marginal expenditures which may not conducive for long run development, then loans may be a more optimal type of aid compared to grants. It may also be a fruitful line of research to analyze the flypaper effect of the different categories of development aid when judging their effectiveness. 


\section{Chapter 5}

\section{Conclusion and Areas of Future Research}

This dissertation broadly addresses the foreign aid practices of the Development Assistance Committee (DAC) countries. Specifically, two questions are analyzed. First, do institutional factors help explain the levels of tied aid observed in the DAC countries. Second, does the distribution of foreign aid, both in aggregate and disaggregate terms, help solicit political support for DAC countries by influencing the voting behavior of aid recipients and aligning the recipients' preferences with those of the donors. The DAC countries are analyzed because each member country has a significant foreign aid program and they are the primary donors of bilateral foreign aid, accounting for almost 74 percent of total ODA gross disbursements since 1991. Despite the attractiveness of studying the major foreign aid donors together, much of the research in the foreign aid literature focuses on individual countries, with the United States being the most frequently studied country. By analyzing all 22 DAC countries, this dissertation extends the previous research.

The primary research question in Chapter 2 is whether institutional factors within the governments of the DAC countries, such as fragmentation of the executive power and the position of government vis-à-vis legislative composition, help explain why real levels of tied aid remain significantly above the zero bound despite the decades long campaign by aid reformers to reduce and ultimately eliminate this inefficient practice. The chapter estimates a variant of the models used in the political competition literature exploring how fragmented political power affects fiscal policy. The results show as the executive power becomes more fragmented, particularly as the number of spending ministers and the number of political parties in the governing coalition increases, countries increase the real level of tied aid. As for the position of government vis-à-vis legislative competition, as the percentage of excess seats in parliament and 
the number of political parties with representation in government increases, countries increase the real level of tied aid.

Chapter 3 analyzes the effectiveness of DAC countries in "directing" the political relationship with aid recipient countries through the use of foreign aid disbursements. An empirical model is employed to test the hypothesis that increasing foreign aid, measured in aggregate terms, increases voting coincidence between donor and recipient countries in the postCold War era. The results show that of the non-Nordic countries considered, Canada, France, Spain, and the United Kingdom exhibit a positive relationship between voting coincidence and foreign aid distribution while the United States, the world's largest aid donor, does not demonstrate a conclusive relationship. These results are robust to a number of sensitivity analyses which include additional variables and converting the dataset into 3 year averaged observations per country to analyze longer term trends in changes to voting coincidence. The results also open up the possibility that DAC countries are able to free ride off of other DAC countries in regards to aid giving because of the close voting coincidences among them. The factor analysis performed provides some evidence towards this hypothesis.

Chapter 4 extends the research of chapter 3 by disaggregating the bilateral foreign aid measures and applying the analysis to all 22 DAC countries. Total bilateral aid is disaggregated into loans and grants and project, program, and humanitarian aid. Program aid is further disaggregated into budget aid, food aid, and debt relief. Disaggregated measures are employed because the composition of aid has changed over time and different categories and types of aid may exert different macroeconomic effects because donor and recipient countries attach different utility to each category of aid. The results show that in the post Cold War era disaggregated aid measures do not show a robust influence on voting coincidence for most of the DAC countries. 
Many of the aid measures that were significant in the basic model were sensitive to the inclusion of additional explanatory variables and the recipient countries considered. The results in chapters 3 and 4 may differ because of the fungibility of development aid. If donors have the ability to move money between aid categories and towards their preferred marginal expenditures, recipients may be more interested in the total aid they receive rather than the individual aid categories, obscuring the statistical results of individual aid categories.

Although the research performed in this dissertation extended the previous foreign aid literature in a number of significant ways, it also created other avenues of possible fruitful research extensions. While chapter 2 examines how the institutional framework of donor countries impacts the amount of aid they tie, another area of interest is how these institutional factors affect the distribution of aid. For example, it is noted in the literature that improving the social development in recipient countries is becoming a much greater focus for donor countries in why aid is disbursed. This leads to the question of whether institutional factors within donor countries are impediments to the changing composition in aid disbursements. Institutional reasons may also exist for the differences in donor countries' aid commitments and disbursements. For example, is the gap between commitments and disbursements due in some part to the internal working of the donor country or are external factors involved?

The results in chapters 3 and 4 also encourage additional research into the political influence of foreign aid. Measuring voting coincidence in the United Nations General Assembly may not be broad enough measure of political support. Previous research indicates countries attach different utilities to the different votes in the UN so it is possible that countries also attach different utilities to different international organizations. For example, do foreign aid distributions affect the rulings of the Dispute Settlement Board of the World Trade 
Organization? Do donor countries seek to maximize their international influence across the multiple international organizations or do they focus on one body? If donor countries try to maximize their influence in different organizations, why and how do the donor countries choose one organization over another? Also, is there an optimal strategy to maximize total political influence?

The political influence literature of foreign aid could also shift focus from the donors to the recipients. During the Cold War, research shows that developing countries often took advantage of the fears of the Soviet Union and the United States to maximize the amount of foreign aid they received. With the Cold War in the distant past, do recipients still use donor fears to their advantage? For example, how has the recent "War on Terrorism" affected recipient countries' ability to secure aid? Also, has the shift towards social development and a focus on poverty given recipient countries more or less power relative to donor countries in foreign aid distribution?

A last area of additional research may analyze how the recent global financial crisis will affect the attempt to meet the Millennium Development Goals (MDGs). Greece, Ireland, Portugal, and Spain are all DAC countries who have either accepted large international bailouts or are in danger of having to accept them. These bailouts often are accompanied by severe austerity measures. How will the foreign aid of these countries be affected, if they are at all, considering foreign aid would seem to be a politically easy program to eliminate, at least from a public perception point of view? Will the recent financial crisis again shift the focus of foreign aid to structural adjustment, this time to developed rather than developing nations, and therefore choke off resources that were destined for the MDGs? 
The literature on foreign aid is vast but will continue to offer researchers new and exciting avenues of research because of the dynamic evolution of the worldwide economy and the ability of technology to shrink the world. This dissertation is just one more additional piece of the ever expanding body of knowledge. 


\section{References}

Abramowitz, Alan and Saunders, Kyle (1998). "Ideological Realignment in the U.S. Electorate," The Journal of Politics, 60(3): 634-652.

ActionAid International (2005), Real Aid: Making Technical Assistance Work.

Addison, Tony (2000). Aid and Conflict in F. Tarp (ed.) Foreign Aid and Development: Lessons Learnt and Directions for the Future, Routledge Studies in Development Economics 17.

Alesina, Alberto and Dollar, David (2000). "Who Gives Foreign Aid to Whom and Why?" Journal of Economic Growth, 5: 33-63.

Anderson, T.W., and Hsiao, Cheng (1981). "Estimation of Dynamic Models with Error Components," Journal of the American Statistical Association, 76(375): 598-606.

Arellano, Manuel and Bond, Stephen (1991). "Some Tests of Specification for Panel Data: Monet Carlo Evidence and an Application to Employment Equations," Review of Economic Studies, 58: 277-297.

Aryeetey, Ernest (1995). “Aid Effectiveness in Ghana,” Legon: Institute of Statistics and Social and Economic Research, University of Ghana. Mimeo.

Aryeetey, Ernest, Osei, Baffour, and Quartey, Peter (2003). "Does Tying Aid Make it More Costly? A Ghanaian Case Study," Institute of Statistical, Social, and Economic Research, University of Ghana.

Asiedu, Elizabeth and Nandwa, Boaz (2007). "On the Impact of Foreign Aid in Education on Growth: How Relevant is the Heterogeneity of Aid Flows and the Heterogeneity of Aid Recipients," Review of World Economics, 143(4): 631-649.

Attanasio, Orazio P., Picci, Lucio, and Scorcu, Antonello E. (2000). "Saving, Growth, and Investment: A Macroeconomic Analysis Using a Panel of Countries," The Review of Economics and Statistics, 82(2): 182-211.

Baffour, Osei (2004). "The Cost of Aid Tying to Ghana," AERC Research Paper 144, African Economic Research Consortium.

Baltagi, Badi H., Griffin, James M., Xiong, Weiwen (2000). "To Pool or Not to Pool: Homogenous Versus Heterogeneous Estimators Applied to Cigarette Demand," The Review of Economics and Statistics, 82(1): 117-126.

Barnebeck Anderson, Thomas, Harr, Thomas, and Tarp, Finn (2006). "On US Politics and IMF Lending," European Economic Review, 50(7): 1843-1862.

Barro, Robert and Lee, Jong-Wha (2005). "IMF Programs: Who is Chosen and What are the 
Effects," Journal of Monetary Economics, 52; 1245-1269.

Bauer, Peter (1972). Dissent on Development, Cambridge: Harvard University Press.

Bernstein, Samuel and Alpert, Eugene (1971). "Foreign Aid and Voting Behavior in the United Nations: The Admission of Communist China," Orbis, 15(3): 963-977.

Berthelemy, Jean-Claude and Tichit, Ariane (2004). "Bilateral Donors Aid-Aid Allocation Decisions: A Three-Dimensional Panel Analysis," International Review of Economics and Finance, 13(3): 963-977.

Besley, Timothy, Persson, Torsten, Sturm, Daniel (2010). "Political Competition, Policy and Growth: Theory and Evidence from the US," The Review of Economic Studies, 77(4): 1329-1352.

Bhagwati, Jagdish N., Brecher, Richard A., and Hatta, Tatsuo (1985). "The Generalized Theory of Transfers and Welfare: Exogenous (Policy-Imposed) and Endogenous (TransferInduced) Distortions," The Quarterly Journal of Economics, 696-714.

Boone, Peter. (1996). "Politics and the Effectiveness of Foreign Aid," European Economic Review, 40: 289-330.

Boschini, Anne and Olofsgard, Anders (2001). "Foreign Aid: An Instrument for Fighting Poverty or Communism?" manuscript, Stockholm University.

Bulow, Jeremy and Rogoff, Kenneth (2005). "Grants Versus Loans for Development Banks," The American Economic Review, 95(2): Papers and Proceedings of the One Hundred Seventeenth Annual Meeting of the American Economic Association, Philadelphia, PA, January 7-9, 2005, pp. 393-397.

Burnside, Craig and Dollar, David (2000). "Aid, Policies, and Growth," American Economic Review, 90: 847-868.

Cassen, Robert (1986). Does Aid Work? Oxford University Press: Oxford.

Cassen, Robert (1994). Does Aid Work? Oxford University Press: Oxford ( $2^{\text {nd }}$ Edition).

Chao, Chi-Chur and Yu, Eden (1999). "Foreign Aid, the Environment, and Welfare," Journal of Development Economics, 59: 553-564.

Cheibub, Jose, Gandhi, Jennifer, and Vreeland, James (2010). "Democracy and Dictatorship Revisited," Public Choice, 143: 67-101.

Chenery, Hollis B. and Strout, Alan M. (1966). "Foreign Assistance and Economic Development," American Economic Review, 56(4): 679-735. 
Clemens, Michael, Radelet, Steven, and Bhavnani, Rikhil (2004). "Counting Chickens When They Hatch: The Short-Term Effect of Aid on Growth," Center for Global Development Working Paper 44. Washington, D.C.

Collier, Paul (1997). "The Failure of Conditionality," In Perspectives on Aid and Development, edited by Catherine Gwin and J. Nelson. Washington, DC: Overseas Development Council, pp.51-71.

De Haan, Jakob and Sturm, Jan-Egbert (1994). "Political and Institutional Determinants of Fiscal Policy in the European Community," Public Choice, 80: 157-172.

Denger, S. and Sen, Amartya. (1991). "Military Expenditure, Aid, and Economic Development," The World Bank Economic Review, pp. 159-189.

Dollar, David, and Levin, Victoria (2004). "The Increasing Selectivity of Foreign Aid, 19842002,” World Development, 34(12): 2034-2046.

Dreher, Axel and Sturm, Jan-Egbert (2006). "Do IMF and World Bank Influence Voting in the UN General Assembly?” KOF Working Paper 137, ETH Zurich.

Dreher, Axel, Nunnenkamp, Peter, and Thiele, Rainer (2008). "Does US Aid Buy UN General Assembly Votes? A Disaggregated Analysis,” Public Choice, 136: 139-164.

Easterly, William (2001). The Elusive Quest for Growth, Cambridge: MIT Press.

Easterly, William (2006). The White Man's Burden, New York: Penguin Press.

Escaleras, Monica, Anbarci, Nejat, and Resister, Charles (2007). "Public Sector Corruption and Major Earthquakes: A Potentially Deadly Interaction,” Public Choice, 132(1-2): 209-230.

Europa Yearbook. Europa World Year Book. Various editions. London: Europa Publications.

Fleck, Robert K. and Kilby, Christopher (2001). "Foreign Aid and Domestic Politics: Voting in Congress and the Allocation of USAID Contracts across Congressional Districts," Southern Economic Journal 67(3): 598-617.

Fleck, Robert K. and Kilby, Christopher (2006a). "How Do Political Changes Influence US Bilateral Aid Allocations? Evidence from Panel Data," Review of Development Economics, 10(2): 210-223.

Fleck, Robert K. and Kilby, Christopher (2006b). "World Bank Independence: A Model and Statistical Analysis of US Influence," Review of Development Economics, 10(2): 224240.

Friedman, Milton (1958). "Foreign Economic Aid," Yale Review, 47: 500-516. 
Gates, Scott and Hoeffler, Anke (2004). "Global Aid Allocation: Are Nordic Donors Different?" Working Paper. The Centre for the Study of African Economies Working Paper Series.

Garrett, Thomas and Sobel, Russell (2003). "The Political Economy of FEMA Disaster Payments," Economic Inquiry, 41(3): 496-509.

Grier, Robin (1997). “The Effect of Religion on Economic Development: A Cross National Study of 63 Former Colonies," Kyklos, 50(1): 47-62.

Harrigan, Jane, Wang, Chengang, and El-Said, Hamed (2006). "The Economic and Political Determinants of IMF and World Bank Lending in the Middle East and North Africa," World Development, 34(2): 247-270.

Hawes, Michael (2004). "Inflationary Influence: The Diminishing Effect of US Foreign Aid on UN Voting," University of California, San Diego, mimeo.

Hermes, Niels and Lensink, Robert (2001). "Changing the Conditions for Development Aid: A New Paradigm?” The Journal of Development Studies, 37(6): 1-16.

Holcombe, Randall and Sobel, Russell (1996). "The Stability of International Coalitions in United Nations Voting from 1946 to 1973," Public Choice, 86: 17-34.

Huber, Gerald, Kocher, Martin, and Sutler, Matthias (2003). "Government Strength, Power Dispersion in Governments and Budget Deficits in OECD-Countries: A Voting Power Approach," Public Choice, 116(3-4): 333-350.

International Monetary Fund (IMF), Direction of Trade Statistics (DOTS) February 2009.

Isenman, Paul and Ehrenpreis, Dag (2003). Results of the OECD DAC/Development Centre Experts' Seminar on "Aid Effectiveness and Selectivity: Integrating Multiple Objectives into Aid Allocations," DAC Journal, 4(3): 7-25.

Jepma, Catrinus J. (1991). “The Tying of Aid” Development Centre Studies, Development Centre of the Organization for Economic Co-Operation and Development.

Judson, Ruth A. and Owen, Ann L. (1999). "Estimating Dynamic Panel Models: A Guide for Macroeconomists," Economic Letters, 65: 9-15.

Kaiser, H.F. (1960). “The Application of Electronic Computers to Factor Analysis,” Educational and Psychological Measurement, 20: 141-151.

Kato, Masakatsu (1969). “A Model of US Foreign Aid Allocation: An Application of a Rational Decision-Making Scheme," In Approaches to Measurement in International Relations, edited by John E. Mueller. Appleton Century Croft, New York.

Kegley, Charles and McGowan, Patrick (1981). The Political Economy of Foreign Policy. 
Beverly Hills: Sage Publications.

Kegley, Charles and Hook, Steven (1991). "US Foreign Aid and UN Voting: Did Reagan's Linage Strategy Buy Defense or Defiance?” International Studies Quarterly, 35(3): 295312.

Keohane, Robert (1967). "The Study of Political Influence in the General Assembly," International Organization, 21(2): 221-237.

Kilby, Christopher (2006). "Donor Influence in MDBs: The Case of the Asian Development Bank," The Review of International Organizations, 21(1): 173-195.

Kim, Soo Yeon and Russett, Bruce (1996). "The New Politics of Voting Alignment in the United Nations General Assembly," International Organization, 50(4): 629-652.

Kuziemko, Ilyana and Werker, Eric (2006). "How Much is a Seat on the Security Council Worth? Foreign Aid and Bribery at the United Nations," Journal of Political Economy, 114(5): 905-930.

Lahiri, Sajal and Raimondos-Moller, Pascalis (2000). "Lobbying by Ethnic Groups and Aid Allocation," The Economic Journal 110(462) Conference Papers: C62-C79.

Langhammer, Rolf J. (2004). "Halving Poverty by Doubling Aid: Is There Reason for Optimism," The World Economy, 27(1): 81-98.

Laver, Michael and Schofield, Norman. (Eds). (1990). Multiparty Government. Oxford: Oxford University Press.

Leandro, Jose E., Schafer, Hartwig, and Gaspar, Frontini (1999). "Towards a More Effective Conditionality: An Operational Framework,” World Development, 27(2): 285-299.

Leogrande, William M. and Brenner, Phillip (1993). "The House Divided: Ideological Polarization over Aid to the Nicaraguan 'Contras'," Legislative Studies Quarterly, 18(1): 105- 136.

Leontief, Wassily (1936). "Note on the Pure Theory of Capital Transfer," in Explorations in Economics: Notes and Essays Contributed in the Honor of F. W. Taussig, New York: McGraw-Hill Book Company.

Levy, Victor (1987). “Anticipated Development Assistance, Temporary Relief Aid, and Consumption Behavior of Low-Income Countries," The Economic Journal, 97: 446-458.

Lundborg, Per (1998). "Foreign Aid and International Support as a Gift Exchange," Economics and Politics, 10(2): 127-142.

Maizel, A. and Nissanke, M. K. (1984). "Motivation for Aid to Developing Countries," World 
Development, 12: 879-900.

Mascarenhas, Raechelle and Sandler, Todd (2006). "Do Donors Cooperatively Fund Foreign Aid," The Review of International Organizations 1(4): 337-357.

Mavrotas, George and Ouattara, Bazoumana (2006). "Public Fiscal Behavior and Aid Heterogeneity in Aid-Recipient Economies," The Journal of Developing Areas, 39(2): 115.

Mavrotas, George and Nunnenkamp, Peter (2007). "Foreign Aid Heterogeneity: Issues and Agenda," Review of World Economics, 143(4): 585-595.

Maxwell, Simon and Riddell, Roger (1998). "Conditionality or Contract: Perspectives on Partnership for Development,” Journal of International Development, 10: 257-268.

McGillivray, Mark. (2003). "Aid Effectiveness and Selectivity: Integrating Multiple Objectives into Aid Allocations," DAC Journal 4(3): 27-40.

McGillivray, Mark and Morrissey, Oliver (2000). "Aid Fungibility in Assessing Aid: Red Herring or True Concern," Journal of International Development, 12(3): 413-428.

Meernik, James, Kreuger, Eric, and Poe, Steven (1998). "Testing Models of U.S. Foreign Policy: Foreign Aid During and After the Cold War," Journal of Politics, 60: 63-85.

Morey, Daniel and Lai, Brian (2006). "Impact of Regime Type on the Influence of US Foreign Aid," Foreign Policy Analysis, 2(4): 385-404.

Morgan, Dan (1995). "Where Foreign Aid Gets Down to Business," Washington Post, June 12, p. A-4.

Morgenthau, Hans J. (1962). “A Political Theory of Foreign Aid," American Political Science Review 56(2): 301-309.

Mosley, Paul, Harrigan, Jane, and Toye, John (1995). Aid and Power: The World Bank and Policy Based Lending, London: Routledge.

Moyo, Dambisa (2009). Dead Aid: Why Aid is Not Working and How There is a Better Way for Africa. Farrar, Staus, and Giroux: New York.

Nelson, Joan B. (1968). Aid, Influence, and Foreign Policy, New York: MacMillan.

Neumayer, Eric. (2003). The Pattern of Aid Giving: The Impact of Good Governance on Development Assistance, Routledge: New York.

Nickell, Stephen (1981). "Biases in Dynamic Models with Fixed Effects," Econometrica, 49(6): 1417-1426. 
Oatley, Thomas and Yackee, Jason (2004). “American Interests and IMF Lending," International Politics, 41(3): 415-429.

O’Leary, Michael (1967). The Politics of American Foreign Aid, New York: Atherton.

Oneal, John and Russett, Bruce (1999). "Assessing the Liberal Peace with Alternative Specifications: Trade Still Reduces Conflict," Journal of Peace Research, 36(4): 423443.

Organization of Economic Co-operation and Development (2009). Inside the DAC: A Guide to the OECD Development Assistance Committee 2009-2010, Paris, France: The Organization of Economic Co-operation and Development.

Otter, Mark (2003). “Domestic Public Support for Foreign Aid: Does it Matter?” Third World Quarterly, 24(1): 115-125.

Pack, Howard and Pack, Janet R. (1993). "Foreign Aid and the Question of Fungibility," The Review of Economics and Statistics 75(2): 258-265.

Padovano, Fabio and Ricciuti, Roberto (2009). "Political Competition and Economic Performance: Evidence from the Italian Regions," Public Choice 138: 263-277.

Palmer, Glenn, Wohlander, Scott, and Morgan, T. (2002). "Give or Take: Foreign Aid and Foreign Policy Substitutability," Journal of Peace Research, 39(1): 5-26.

Perotti, Roberto and Kontopoulos, Yianos (1999). "Fragmented Fiscal Policy." In J. Poterba and J. von Hagen 9 eds., Fiscal Institutions and Fiscal Performance. Chicago: University of Chicago Press.

Quartey, Peter (2005). "Innovative Ways of Making Aid Effective in Ghana,” Research Paper No. 2005/58, World Institute for Development Economics Research.

Rai, Kul B. (1972). "Foreign Policy and Voting in the UN General Assembly," International Organization, 26(3): 589-594.

Rai, Kul B. (1980). "Foreign Aid and Voting in the UN General Assembly," Journal of Peace Research, 17(3): 269-277.

Rogers, Diane and Rogers, John (2000). "Political Competition and State Government Size: Do Tighter Elections Produce Looser Budgets," Public Choice 105: 1-21.

Roodman, David (2004). “An Index of Donor Performance," Working Paper 42, Center for Global Development, Washington, D.C.

Roodman, David (2006). "How to Do Xtabond2: An Introduction to "Difference" and "System" 
GMM in Stata," Working Paper Number 103, Center for Global Development, Washington, D.C.

Roubini, Nouriel and Sachs, Jeffrey (1989a). "Political and Economic Determinants of Budget Deficits in the Industrial Democracies," European Economic Review, 33: 903-938.

Roubini, Nouriel and Sachs, Jeffrey (1989b). "Government Spending and Budget Deficits in the Industrial Countries,” Economic Policy, 8: 100-132.

Rummel, Rudolph (1970). Applied Factor Analysis, Chicago: Northwestern University Press.

Ruttan, V.W. (1996). United States Development Assistance Policy: The Domestic Politics of Foreign Economic Aid, Baltimore: The Johns Hopkins University Press.

Sachs, Jeffrey. 2005. The End of Poverty: Economic Possibilities for Our Time, New York: Penguin.

Schraeder, Peter J., Hook, Steven W., and Taylor, Bruce (1998). "Clarifying the Foreign Aid Puzzle: A Comparison of American, Japanese, French, and Swedish Aid Flows," World Politics 50(2): 284-323.

Scott, James and Steele, Carie (2011). "Sponsoring Democracy: The United States and Democracy Aid to the Developing World, 1988-2001," International Studies Quarterly, 55(1): 47-69.

Sexton, Edwin and Decker, Terence (1992). "US Foreign Aid: Is it for Friends, Development, or Politics," The Journal of Social, Political, and Economic Studies, 17 (3 and 4): 303-315.

Shepsle, Kenneth and Weingast, Barry (1981). "Political Preferences for the Pork Barrel: A Generalization,” American Journal of Political Science, 25(1): 96-111.

Singer, J. David, Stuart Bremer, and John Stuckey. (1972). "Capability Distribution, Uncertainty, and Major Power War, 1816-2007." in Bruce Russett (ed) Peace, War, and Numbers, Beverly Hills: Sage, 19-48.

Sobel, Russell and Leeson, Pete (2006). “Government's Response to Hurricane Katrina: A Public Choice Analysis," Public Choice, 127(1-2): 55-73.

Sowa, Nii and White, Howard (1997). "An Evaluation of Netherlands Co-financing of World Bank Activities in Ghana," The Hague: Policy and Operations Department, Ministry of Foreign Affairs.

Stigler, George (1972). "Economic Competition and Political Competition," Public Choice, 13(1): 91-106.

Stokke, Olav (Ed.) (1989). Western Middle Powers and Global Poverty: The Determinants of the 
Aid Policies of Canada, Denmark, the Netherlands, Norway, and Sweden. The Scandinavian Institute of African Studies, Uppsala.

Stone, Randall (2004). "The Political Economy of IMF Lending in Africa," American Political Science Review, 98(4): 577-591.

Svensson, Jacob (2003). "Why Conditional Aid Doesn't Work and What Can be Done About It," Journal of Development Economics, 70: 381-402.

Tajoli, Lucia (1999). "The Impact of Tied Aid on Trade Flows between Donor and Recipient Countries," The Journal of International Trade and Economic Development, 8(4): 373388.

Thacker, Strom (1999). “The High Politics of IMF Lending,” World Politics, 52: 38-75.

Therien, Jean-Philippe and Noel, Alain (2000). "Political Parties and Foreign Aid," The American Political Science Review, 94(1): 151-162.

Therien, Jean-Philippe (2002). "Debating Foreign Aid: Right Versus Left," Third World Quarterly, 23(3): 449-466.

Thiele, Rainer, Nunnenkamp, Peter, and Dreher, Axel (2007). "Do Donors Target Aid in Line With the Millennium Development Goals? A Sector Perspective of Aid Allocation," Review of World Economics, 143(4): 596-630.

Trumbull, William. and Wall, H.J. (1994). "Estimating Aid Allocation Criteria with Panel Data," Economic Journal, 104: 876-882.

Villanger, Espen (2004). "Company Influence on Foreign Aid Disbursement: Is Conditionality Credible When Donors Have Mixed Motives?" Southern Economic Journal 71(2):334351.

Voeten, Erik (2000). "Clashes in the Assembly," International Organization, 54(2): 185-215.

Volkerink, Bjorn and De Haan, Jakob (2001). "Fragmented Government Effects on Fiscal Policy: New Evidence," Public Choice, 109: 221-242.

Wang, T.Y. (1999). "US Foreign Aid and UN Voting: An Analysis of Important Issues," International Studies Quarterly, 43(1): 199-210.

Weingast, Barry, Shepsle, Kenneth, and Johnsen, Christopher (1981), "The Political Economy of Benefits and Costs: A Neoclassical Approach to Distributive Politics," The Journal of Political Economy, 89(4): 642-664.

White, Howard (1998). Aid and Macroeconomic Performance: Theory, Empirical Evidence, and Four Country Cases. London: Macmillan. 
White, Howard and Morrissey, Oliver (1997). "Conditionality when Donor and Recipient Preferences Vary,” Journal of International Development, 9(4): 497-505.

Windmeijer, Frank (2005). "A Finite Sample Correction for the Variance of Linear Efficient Two-Step GMM Estimators,” Journal of Econometrics, 126(1): 25-51.

Wittkopf, Eugene R. (1973). "Foreign Aid and United Nations Votes: A Comparative Study," The American Political Science Review, 67(3): 868-888.

Wittman, Donald (1989). "Why Democracies Produce Efficient Results," Journal of Political Economy, 97(6): 1395-1424.

Woldendorp, Jaap, Keman, Hans, and Budge, Ian (1998). "Party Government in 20 Democracies: An Update (1990-1995)," European Journal of Political Research, 33: 125-164.

Wood, Angela and Lockwood, Matthew (1999). The Perestroika of Aid? New Perspectives on Conditionality, Christian Aid, available on the web: http://www.christianaid.org.uk/reports/perastro.htm.

Woods, Ngaire (2000). "The Challenge of Good Governance for the IMF and the World Bank Themselves," World Development, 28(5): 823-841.

Wooldridge, Jeffrey. 2006. Introductory Econometrics: A Modern Approach, Mason: Thomson South-Western.

World Bank, 1998, Assessing Aid: What Works, What Doesn't, and Why, Washington, DC: The World Bank.

World Bank (2009). Data retrieved November 2010 from World Development Indicators Online (WDI) database.

Zimmerman, R.F. (1993). Dollars, Diplomacy, and Dependency: Dilemmas of U.S. Foreign Aid, Colorado: Lynne Reiner. 


\section{Appendices}

\section{Appendix 2A: Variable Description and Sources}

\begin{tabular}{|c|c|c|}
\hline Variable & \multicolumn{2}{c|}{ Description } \\
RTA & Total bilateral aid commitments tied in 2008 constant USD \\
NSM & Number of spending ministers & OECD's online database \\
NPC & Number of political parties in the governing coalition & Europa World Year Book \\
ENPG & Effective number of political parties in the governing coalition & Europa World Year Book \\
ES & Excess number of seats held by the governing coalition & Europa World Year Book and author calculation \\
NPP & Number of political parties with representation in government & Europa World Year Book \\
ENPP & Effective number of political parties with representation in government & Europa World Year Book and author calculation \\
Growth & Annual percentage growth of real Gross Domestic Product & World Development Indicators: World Bank \\
Trade & Trade as a percentage of GDP & World Development Indicators: World Bank \\
\hline
\end{tabular}




\section{Appendix 2B: Summary Statistics}

\begin{tabular}{|c|ccccc|}
\hline Variable & Mean & Std. Dev. & Minimum & Maximum & Observations \\
\hline Total Bilateral Aid Commitments Tied & 936.84 & 1682.77 & 0 & 9597.18 & 532 \\
No. of Spending Ministers & 15.62 & 4.39 & 5 & 31 & 682 \\
No. of Political Parties in Gov. Coalition & 2.32 & 1.45 & 1 & 8 & 682 \\
Effective No. of Political Parties in Gov. Coalition & 1.92 & 1.08 & 1 & 6.31 & 682 \\
Excess No. of Seats held by Gov. Coalition & 11.59 & 21.55 & -49.39 & 71.29 & 651 \\
No. of Political Parties with Representation in Gov. & 7.33 & 3.12 & 2 & 19 & 682 \\
Effective No. of Political Parties with Representation in Gov. & 3.52 & 1.42 & 1.69 & 9.05 & 682 \\
Growth & 2.47 & 2.36 & -8.02 & 11.49 & 681 \\
Trade & 73.84 & 46.74 & 16.01 & 326.76 & 681 \\
\hline
\end{tabular}




\section{Appendix 2C: Political size fragmentation variables correlation matrix}

\begin{tabular}{|c|cccccc|}
\hline \multicolumn{1}{|c}{ NSM } & NPC & ENPG & ES & NPP & ENPP \\
\hline NSM & 1 & & & & & \\
NPC & -0.0981 & 1 & & & & \\
ENPG & -0.1976 & 0.8434 & 1 & & & \\
ES & -0.3967 & 0.2893 & 0.3388 & 1 & & \\
NPP & -0.0896 & 0.5038 & 0.4816 & 0.1652 & 1 & \\
ENPP & -0.2993 & 0.6314 & 0.7015 & 0.1185 & 0.5238 & 1 \\
\hline
\end{tabular}

NSM: Number of Spending Ministers

NPC: Number of Political Parties in the Governing Coalition

ENPG: Effective Number of Political Parties in the Governing Coalition

ES: Excess Number of Seats held by the Governing Coalition

NPP: Number of Political Parties with Representation in Government

ENPP: Effective Number of Political Parties with Representation in Government 


\section{Appendix 2D: All Political Variables}

\begin{tabular}{|c|ccccc|}
\multicolumn{2}{c}{ Variable } & 1 & 2 & 3 & 4 \\
\hline Total Bilateral Aid & \multicolumn{4}{c}{0.81} \\
Commitments Tied (t-1) & & $(0.04)^{* * *}$ & & 23.97 \\
No. of Spending Ministers & 140.06 & 32.37 & 108.05 & -14.97 \\
& $(50.31)^{* * *}$ & $(16.64)^{*}$ & $(47.98)^{* *}$ & \\
No. of Political Parties in & 201.12 & 40.86 & -54.81 & -4.48 \\
Gov. Coalition & $(53.60)^{* * *}$ & $(19.17)^{* *}$ & $(96.29)$ & $(10.12)$ \\
Excess No. of Seats held by & -10.7 & -3.51 & -9.07 & -1.07 \\
Gov. Coalition & $(4.93)^{* *}$ & $(1.74)^{*}$ & $(5.75)$ & $(1.21)$ \\
No. of Political Parties with & -128.67 & -17.54 & 91.94 & 17.40 \\
Representation in Gov. & $(64.12)^{*}$ & $(18.96)$ & $(73.53)$ & $(11.57)$ \\
& 39.17 & 31.45 & 31.12 & 2.34 \\
Growth & $(37.78)$ & $(11.63)^{* * *}$ & $(36.71)$ & $(8.13)$ \\
& 10.11 & 2.46 & -1.59 & -0.91 \\
Trade & $(7.81)$ & $(2.15)$ & $(15.33)$ & $(2.99)$ \\
& -851.82 & -372.04 & -1551.47 & -208.18 \\
Constant & $(736.66)$ & $(372.89)$ & $(1658.48)$ & $(436.97)$ \\
\hline Number of countries & 21 & 21 & 20 & 21 \\
Number of observations & 511 & 463 & 271 & 240 \\
R-squared (within) & 0.46 & 0.85 & 0.30 & 0.08 \\
\hline
\end{tabular}

Standard errors in parentheses: $* * *=1 \%, * *=5 \%, *=10 \%$ significance level.

Columns 1 and 2: Full sample size

Column 3: 1979-1996

Column 4: 1997-2009 


\section{Appendix 3A: Variable Description and Sources}

\begin{tabular}{|c|c|c|}
\hline Variable & Description & Source \\
\hline Voting coincidence & $\begin{array}{l}\text { Number of times a country votes the } \\
\text { same as country X (either voting both } \\
\text { yes, both voting no, both voting } \\
\text { abstentions, or both being absent), } \\
\text { divided by the total number of votes in } \\
\text { each year. }\end{array}$ & $\begin{array}{l}\text { United Nations Bibliographic } \\
\text { Information System and author } \\
\text { calculation }\end{array}$ \\
\hline Level ODA & $\begin{array}{l}\text { The annual amount of a DAC country's } \\
\text { official development assistance as a } \\
\text { proportion of the total official } \\
\text { development assistance received by the } \\
\text { recipient country }\end{array}$ & OECD's online database \\
\hline Democracy & $\begin{array}{l}\text { A dichotomous dummy variable } \\
\text { classifying a country as a democracy } \\
(d=1) \text { or not }(d=0)\end{array}$ & $\begin{array}{l}\text { Cheibub, Gandhi, and Vreeland } \\
\text { (2010) }\end{array}$ \\
\hline National Capability & $\begin{array}{l}\text { Composite indicator of national } \\
\text { capability, based on total population, } \\
\text { urban population, iron and steel } \\
\text { production, energy consumption, military } \\
\text { personnel, and military expenditure. This } \\
\text { measure is generally computed by } \\
\text { summing all observations on each of the } \\
6 \text { capability components for a given year, } \\
\text { converting each state's absolute } \\
\text { component to a share of the international } \\
\text { system, and then averaging across the six } \\
\text { components. }\end{array}$ & $\begin{array}{l}\text { Correlates of War (COW) websit } \\
\text { (http://www.correlatesofwar.org) }\end{array}$ \\
\hline GDPC & $\begin{array}{l}\text { Gross Domestic Product Per Capita } \\
\text { (constant } 2008 \text { USD) }\end{array}$ & $\begin{array}{l}\text { World Development Indicators } \\
\text { (World Bank) }\end{array}$ \\
\hline Exports & $\begin{array}{l}\text { Exports from DAC country } \mathrm{X} \text { to aid } \\
\text { recipient country as a percentage of } \\
\text { recipient GDP }\end{array}$ & $\begin{array}{l}\text { Direction of Trade Statistics } \\
\text { (International Monetary Fund) }\end{array}$ \\
\hline Imports & $\begin{array}{l}\text { Imports from DAC country } \mathrm{X} \text { to aid } \\
\text { recipient country as a percentage of } \\
\text { recipient GDP }\end{array}$ & $\begin{array}{l}\text { Direction of Trade Statistics } \\
\text { (International Monetary Fund) }\end{array}$ \\
\hline GDP growth & $\begin{array}{l}\text { Real Gross Domestic Product growth } \\
\text { (annual percent) }\end{array}$ & $\begin{array}{l}\text { World Development Indicators } \\
\text { (World Bank) }\end{array}$ \\
\hline External Debt & $\begin{array}{l}\text { External debt stocks as a percentage of } \\
\text { Gross National Income }\end{array}$ & $\begin{array}{l}\text { World Development Indicators } \\
\text { (World Bank) }\end{array}$ \\
\hline AFPTL & $\begin{array}{l}\text { Armed forces personnel as a percentage } \\
\text { of the total labor force }\end{array}$ & $\begin{array}{l}\text { World Development Indicators } \\
\text { (World Bank) }\end{array}$ \\
\hline
\end{tabular}




\section{Appendix 3B: Summary Statistics}

\begin{tabular}{|c|c|c|c|}
\hline Variable & Mean & Standard Deviation & Observatioons \\
\hline Voting Coincidence Australia (\% times 100) & 50.38 & 17.93 & 2703 \\
\hline Voting Coincidence Austria (\% times 100$)$ & 54.35 & 18.17 & 2702 \\
\hline Voting Coincidence Belgium (\% times 100$)$ & 50.97 & 17.69 & 2701 \\
\hline Voting Coincidence Canada ( $\%$ times 100$)$ & 49.35 & 16.95 & 2703 \\
\hline Voting Coincidence Denmark (\% times 100$)$ & 52.60 & 17.89 & 2702 \\
\hline Voting Coincidence Finland (\% times 100$)$ & 52.41 & 17.98 & 2703 \\
\hline Voting Coincidence France (\% times 100$)$ & 45.22 & 15.54 & 2703 \\
\hline Voting Coincidence Germany (\% times 100$)$ & 51.44 & 18.03 & 2697 \\
\hline Voting Coincidence Greece (\% times 100$)$ & 51.86 & 19.55 & 2703 \\
\hline Voting Coincidence Ireland (\% times 100$)$ & 54.81 & 18.30 & 2681 \\
\hline Voting Coincidence Italy (\% times 100$)$ & 52.17 & 17.94 & 2703 \\
\hline Voting Coincidence Japan (\% times 100) & 53.71 & 17.83 & 2701 \\
\hline Voting Coincidence Luxembourg (\% times 100$)$ & 51.53 & 17.81 & 2703 \\
\hline Voting Coincidence Netherlands (\% times 100) & 51.26 & 17.82 & 2702 \\
\hline Voting Coincidence New Zealand (\% times 100$)$ & 57.27 & 18.12 & 2699 \\
\hline Voting Coincidence Norway (\% times 100$)$ & 52.48 & 17.52 & 2701 \\
\hline Voting Coincidence Portugal (\% times 100$)$ & 52.96 & 18.04 & 2703 \\
\hline Voting Coincidence Spain (\% times 100$)$ & 53.51 & 17.90 & 2703 \\
\hline Voting Coincidence Sweden (\% times 100) & 54.15 & 18.02 & 2703 \\
\hline Voting Coincidence Switzerland (\% times 100 ) & 56.11 & 16.77 & 1081 \\
\hline Voting Coincidence United Kingdom (\% times 100) & 44.69 & 16.22 & 2701 \\
\hline Voting Coincidence United States ( $\%$ times 100 ) & 16.57 & 10.72 & 2703 \\
\hline Level ODA Australia (\% times 100) & 7.14 & 17.27 & 1364 \\
\hline Level ODA Austria (\% times 100) & 0.80 & 4.97 & 1959 \\
\hline Level ODA Belgium (\% times 100) & 1.38 & 4.84 & 1877 \\
\hline Level ODA Canada (\% times 100) & 1.97 & 24.09 & 2278 \\
\hline Level ODA Denmark (\% times 100 ) & 1.73 & 11.61 & 1534 \\
\hline Level ODA Finland (\% times 100$)$ & 0.48 & 2.10 & 1626 \\
\hline Level ODA France (\% times 100$)$ & 8.93 & 44.63 & 2427 \\
\hline Level ODA Germany (\% times 100) & 6.30 & 25.08 & 2426 \\
\hline Level ODA Greece (\% times 100) & 0.42 & 1.56 & 957 \\
\hline Level ODA Ireland (\% times 100$)$ & 0.63 & 1.99 & 1461 \\
\hline Level ODA Italy (\% times 100$)$ & 2.93 & 14.09 & 1879 \\
\hline Level ODA Japan (\% times 100) & 12.11 & 94.67 & 2511 \\
\hline Level ODA Luxembourg (\% times 100 ) & 0.55 & 1.38 & 1270 \\
\hline Level ODA Netherlands (\% times 100) & 1.12 & 145.29 & 2117 \\
\hline Level ODA New Zealand (\% times 100$)$ & 1.50 & 4.48 & 1345 \\
\hline Level ODA Norway (\% times 100) & 2.43 & 9.55 & 1899 \\
\hline Level ODA Portugal (\% times 100$)$ & 4.16 & 11.58 & 574 \\
\hline Level ODA Spain (\% times 100) & 1.14 & 139.50 & 1717 \\
\hline Level ODA Sweden (\% times 100) & 1.65 & 24.60 & 1907 \\
\hline Level ODA Switzerland (\% times 100$)$ & 0.95 & 20.61 & 1903 \\
\hline Level ODA United Kingdom (\% times 100) & 3.11 & 35.98 & 2155 \\
\hline Level ODA United States (\% times 100) & 16.23 & 344.56 & 2224 \\
\hline Democracy & 0.47 & 0.50 & 2759 \\
\hline National Capability (\% times 100$)$ & 0.37 & 1.41 & 2548 \\
\hline GDP Per Capita & 3744.26 & 5736.05 & 2597 \\
\hline GDP growth & 4.02 & 7.04 & 2610 \\
\hline External Debt & 77.55 & 94.74 & 2045 \\
\hline AFPTL & 1.73 & 2.22 & 2509 \\
\hline
\end{tabular}




\section{Appendix 4A: Variable Description and Source}

\begin{tabular}{|c|c|c|}
\hline Variable & Description & Source \\
\hline Voting Coincidence & $\begin{array}{l}\text { Number of times a country votes the same as country X } \\
\text { (either voting both yes, both voting no, both voting } \\
\text { abstentions, or both being absent), divided by the total } \\
\text { number of votes in each year. }\end{array}$ & $\begin{array}{l}\text { United Nations Bibliographic } \\
\text { Information System and author } \\
\text { calculation }\end{array}$ \\
\hline Project Aid & $\begin{array}{l}\text { Sum of DAC sector codes } 110,120,130,140,150,160, \\
200,210,220,230,240,250,310,320,330,400,410,420, \\
430, \text { and } 920 \text { in percent of GDP }\end{array}$ & Creditor Reporting System \\
\hline Program Aid & $\begin{array}{l}\text { Sum of DAC sector codes } 500,510,520,530 \text {, and } 600 \text { in } \\
\text { percent of GDP }\end{array}$ & Creditor Reporting System \\
\hline Humanitarian Aid & $\begin{array}{l}\text { Sum of DAC sector codes } 720,730 \text {, and } 740 \text { in percent of } \\
\text { GDP }\end{array}$ & Creditor Reporting System \\
\hline Budget Support & DAC sector code 510 in percent of GDP & Creditor Reporting System \\
\hline Food Aid & DAC sector code 520 in percent of GDP & Creditor Reporting System \\
\hline Debt Relief & DAC sector code 600 in percent of GDP & Creditor Reporting System \\
\hline Loans & ODA/OA loans in percent of GDP & Creditor Reporting System \\
\hline Grants & ODA/OA grants in percent of GDP & Creditor Reporting System \\
\hline Democracy & $\begin{array}{l}\text { A dichotomous dummy variable clas sifying a country as } \\
\text { a democracy }(\mathrm{d}=1) \text { or not }(\mathrm{d}=0)\end{array}$ & $\begin{array}{l}\text { Cheibub, Gandhi, and Vreeland } \\
\text { (2010) }\end{array}$ \\
\hline National Capability & $\begin{array}{l}\text { Composite indicator of national capability, based on total } \\
\text { population, urban population, iron and steel production, } \\
\text { energy consumption, military personnel, and military } \\
\text { expenditure. This measure is generally computed by } \\
\text { summing all observations on each of the } 6 \text { capability } \\
\text { components for a given year, converting each state's } \\
\text { absolute component to a share of the international } \\
\text { system, and then averaging across the six components. }\end{array}$ & $\begin{array}{l}\text { Correlates of War (COW) website } \\
\text { (http://www.correlates ofwar.org) }\end{array}$ \\
\hline GDP per capia & Gross Domestic Product Per Capita (constant 2008 USD) & $\begin{array}{l}\text { World Development Indicators } \\
\text { (World Bank) }\end{array}$ \\
\hline Exports & $\begin{array}{l}\text { Exports from DAC country } \mathrm{X} \text { to aid recipient country as a } \\
\text { percentage of recipient GDP }\end{array}$ & $\begin{array}{l}\text { Direction of Trade Statis tics } \\
\text { (International Monetary Fund) }\end{array}$ \\
\hline Imports & $\begin{array}{l}\text { Imports from DAC country } X \text { to aid recipient country as } \\
\text { a percentage of recipient GDP }\end{array}$ & $\begin{array}{l}\text { Direction of Trade Statis tics } \\
\text { (International Monetary Fund) }\end{array}$ \\
\hline GDP growth & Real Gross Domestic Product growth (annual percent) & $\begin{array}{l}\text { World Development Indicators } \\
\text { (World Bank) }\end{array}$ \\
\hline External Debt & $\begin{array}{l}\text { External debt stocks as a percentage of Gross National } \\
\text { Income }\end{array}$ & $\begin{array}{l}\text { World Development Indicators } \\
\text { (World Bank) }\end{array}$ \\
\hline
\end{tabular}

